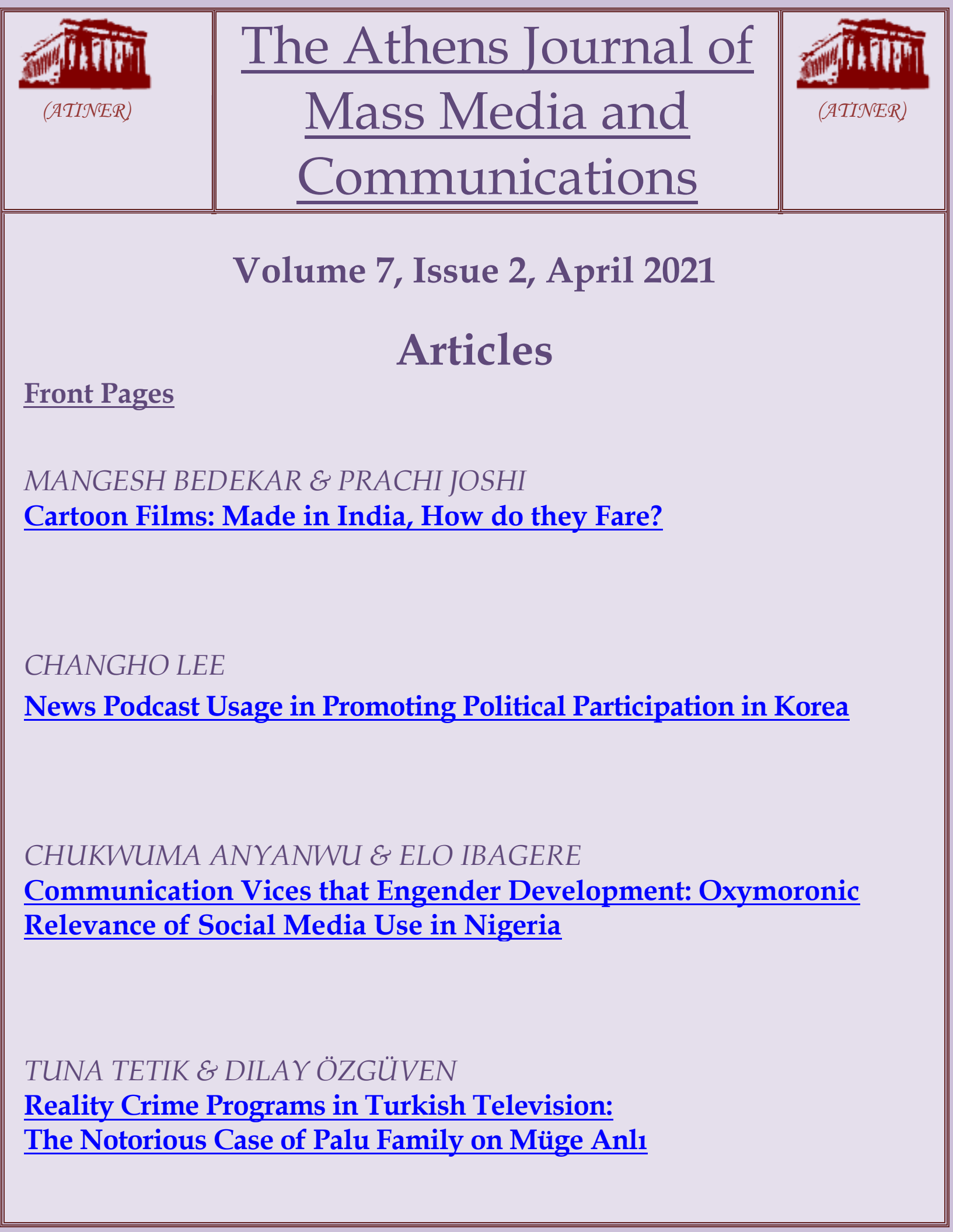




\section{Mission}

ATINER is an Athens-based World Association of Academics and Researchers based in Athens. ATINER is an independent and non-profit Association with a Mission to become a forum where Academics and Researchers from all over the world can meet in Athens, exchange ideas on their research and discuss future developments in their disciplines, as well as engage with professionals from other fields. Athens was chosen because of its long history of academic gatherings, which go back thousands of years to Plato's Academy and Aristotle's Lyceum. Both these historic places are within walking distance from ATINER's downtown offices. Since antiquity, Athens was an open city. In the words of Pericles, Athens"... is open to the world, we never expel a foreigner from learning or seeing". ("Pericles' Funeral Oration", in Thucydides, The History of the Peloponnesian War). It is ATINER's mission to revive the glory of Ancient Athens by inviting the World Academic Community to the city, to learn from each other in an environment of freedom and respect for other people's opinions and beliefs. After all, the free expression of one's opinion formed the basis for the development of democracy, and Athens was its cradle. As it turned out, the Golden Age of Athens was in fact, the Golden Age of the Western Civilization. Education and (Re)searching for the 'truth' are the pillars of any free (democratic) society. This is the reason why Education and Research are the two core words in ATINER's name. 
The Athens Journal of Mass Media and

Communications

ISSN NUMBER: 2407-9677 - DOI: 10.30958/ajmmc

Volume 7, Issue 2, April 2021

Download the entire issue ( $\underline{\mathrm{PDF}})$

$\underline{\text { Front Pages }}$

i-viii

Cartoon Films: Made in India, How do they Fare? 79 Mangesh Bedekar E Prachi Joshi

News Podcast Usage in Promoting Political Participation 107 in Korea

Changho Lee

Communication Vices that Engender Development:

Oxymoronic Relevance of Social Media Use in Nigeria Chukwuma Anyanwu \& Elo Ibagere

Reality Crime Programs in Turkish Television:

The Notorious Case of Palu Family on Müge Anlı

Tuna Tetik \& Dilay Özgüven 


\section{The Athens Journal of Mass Media and Communications Editorial and Reviewers' Board}

$\underline{\text { Editors }}$

- Dr. John Pavlik, Head, Mass Media and Communication Unit, ATINER \& Professor, Journalism and Media Studies, School of Communication and Information, Rutgers University, USA.

- Dr. Yorgo Pasadeos, Director, Social Sciences Division, ATINER \& Professor Emeritus, University of Alabama USA.

- Dr. Patrick Vyncke, Professor of Communication Management, Department of Communication Sciences, Ghent University, Belgium.

\section{Editorial Board}

- Dr. John Pavlik, Head, Mass Media and Communication Unit, ATINER \& Professor, Rutgers University, USA.

- Dr. Burak Dogu, Academic Member, ATINER \& Vice Dean, Izmir University of Economics, Turkey.

- Dr. Andzela Armoniene, Head of The Fund Young Researcher, Lithuania.

- Dr. Mariam Gersamia, Professor \& Head, Division of Journalism and Mass Communication, Ivane Javakhishvili Tbilisi State University, Georgia.

- Dr. Egle Jaskuniene, Associate Professor \& Vice Dean for Research, Faculty of Creative Industries, Vilnius Gediminas Technical University, Lithuania.

- Dr. Berrin Yanikkaya, Academic Member, ATINER and Professor \& Head, School of Communication Studies, Auckland University of Technology, New Zealand.

- Dr. Dali Osepashvili, Professor, Department of Journalism and Mass Communication, Ivane Javakhishvili Tbilisi State University, Georgia.

- Dr. Walter Wymer, Academic Member, ATINER \& Professor of Marketing, University of Lethbridge, Canada.

- Dr. Alan Albarran, Academic Member, ATINER \& Professor, The University of North Texas, USA.

- Dr. Patricia L. Dooley, Elliott Distinguished Professor of Communication, Wichita State University, USA.

- Dr. Catherine Ann Collins, Professor, Department of Rhetoric, Willamette University, USA.

- Dr. Pamela Doyle Tran, Professor of Electronic News, University of Alabama, USA.

- Dr. S. Andrews, Professor, Department of Information Technology, Mahendra Engineering College, India.

- Dr. Emmanuel Ngwainmbi, Department of Communication Studies, The University of North Carolina, USA.

- Dr. Zsolt Alfred Polgar, Academic Member, ATINER \& Associate Professor, 
Technical University of Cluj-Napoca, Romania.

- Dr. Margaret M. Cassidy, Academic Member, ATINER \& Associate Professor, Adelphi University, USA.

- Dr. Baris Coban, Associate Professor, Communication Sciences Department, Dogus University, Turkey.

- Dr. Ulas Basar Gezgin, Associate Professor of Applied Communication, British University Vietnam, Vietnam.

- Dr. Anya Luscombe, Associate Professor and Head, Department of Academic Core, University College Roosevelt, The Netherlands.

- Dr. Charles Obot, Academic Member, ATINER \& Associate Professor, University of Uyo, Nigeria.

- Dr. Ceren Sozeri, Associate Professor, Faculty of Communication, Galatasaray University, Turkey.

- Dr. Matthew D. Matsaganis, Assistant Professor, Department of Communication, State University of New York (SUNY), USA.

- Dr. Geneviève A. Bonin, Assistant Professor, University of Ottawa, Canada.

- Dr. Klarissa Lueg, Assistant Professor, Aarhus University, Denmark.

- Dr. George Pavlou, Assistant Professor, European University, Cyprus.

- Dr. Yolandi Slabbert, Senior Lecturer, Department of Communication Science, University of South Africa, South Africa.

- Dr. Daniel Binns, Academic Member, ATINER \& Lecturer, RMIT University, Australia.

- Dr. Binoy Kampmark, Lecturer in Social Sciences, School of Global, Urban and Social Studies, RMIT University, Australia.

- Dr. Sarah Sparke, Academic Member, ATINER \& Research Associate, CMIR, University of the West of England, UK.

- Dr. Vittoria Sacco, Postdoctoral Assistant, Neuchatel University, Switzerland.

- Ms. Mania Alehpour, PhD Candidate, University of Tehran, Iran.

- General Managing Editor of all ATINER's Publications: Ms. Afrodete Papanikou

- ICT Managing Editor of all ATINER's Publications: Mr. Kostas Spyropoulos

- Managing Editor of this Journal: Ms. Olga Gkounta (ㅁio $)$

\section{Reviewers' Board}

Click Here 


\section{President's Message}

All ATINER's publications including its e-journals are open access without any costs (submission, processing, publishing, open access paid by authors, open access paid by readers etc.) and is independent of presentations at any of the many small events (conferences, symposiums, forums, colloquiums, courses, roundtable discussions) organized by ATINER throughout the year and entail significant costs of participating. The intellectual property rights of the submitting papers remain with the author. Before you submit, please make sure your paper meets the basic academic standards, which includes proper English. Some articles will be selected from the numerous papers that have been presented at the various annual international academic conferences organized by the different divisions and units of the Athens Institute for Education and Research. The plethora of papers presented every year will enable the editorial board of each journal to select the best, and in so doing produce a top-quality academic journal. In addition to papers presented, ATINER will encourage the independent submission of papers to be evaluated for publication.

The current issue is the second of the seventh volume of the Athens Journal of Mass Media and Communications (AJMMC), published by the Mass Media \& Communication Unit of ATINER.

Gregory T. Papanikos

President

ATINER 


\section{Athens Institute for Education and Research}

\section{A World Association of Academics and Researchers}

19th Annual International Conference on Communication and Mass Media, 10-13 May 2021, Athens, Greece

The Mass Media \& Communication Unit of ATINER organizes its 19th Annual International Conference on Communication and Mass Media, 10-13 May 2021, Athens, Greece sponsored by the Athens Journal of Mass Media and Communications. The aim of the conference is to bring together academics and researchers of Communications, Mass Media and other related disciplines. Please submit a proposal using the form available (https://www.atiner.gr/2021/FORM-MED.doc).

- Abstract Submission: 29 March 2020

- Acceptance of Abstract: 4 Weeks after Submission

- Submission of Paper: 12 April 2021

\section{Academic Members Responsible for the Conference}

- Dr. John Pavlik, Head, Mass Media and Communication Research Unit, ATINER \& Professor, Rutgers University, USA.

- Dr. Yorgo Pasadeos, Director, Social Sciences Division, ATINER \& Professor Emeritus, University of Alabama USA.

\section{Social and Educational Program}

The Social Program Emphasizes the Educational Aspect of the Academic Meetings of Atiner.

- Greek Night Entertainment (This is the official dinner of the conference)

- Athens Sightseeing: Old and New-An Educational Urban Walk

- Social Dinner

- Mycenae Visit

- Exploration of the Aegean Islands

- Delphi Visit

- Ancient Corinth and Cape Sounion

\section{Conference Fees}

Conference fees vary from $400 €$ to $2000 €$ Details can be found at: https://www.atiner.gr/2019fees 


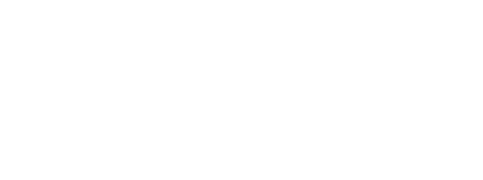




\title{
Cartoon Films: Made in India, How do they Fare?
}

\author{
By Mangesh Bedekar \& Prachi Joshi ${ }^{ \pm}$
}

Cartoons, these days have become an integral part of every child's childhood. They are amongst the most prominent forms of entertainment for children. With the advent of the nuclear family and single child families, with no mate/partner to interact, play or learn from, it is with the help of cartoons that kids are exposed to the various facets of the world around us. Cartoon films screened on most TV sets in Indian homes were majorly dubbed versions of successful cartoon films from USA, Japan, Canada, etc. From around 2003 onwards, some Indian cartoons started to appear on TV especially after the Cable TV came to Indian homes. This paper looks at the cartoons, which are made in India, made for India, and their co-relations with the cartoons which are otherwise screened on Indian TV sets, which are dubbed versions of cartoon films from around the world. These Indian cartoons are analysed and correlated with each other based on various attributes namely, the locale, the age of the protagonist, number of episodes, number of character in the movie, gender ratio, etc. The observations and conclusions done in this study are enlisted and presented.

Keywords: cartoon films, children's television, comparative analysis, gender stereotypes, social science research

\section{Introduction}

Children and pre-teens enjoy watching cartoon films on television. Cartoons are one of the most popular entertainment means for children on television. Watching cartoon films has become an integral part of children's daily routine.

Children watch multitudes of cartoons films and re-runs of the same cartoon films. Various studies have shed light on the impact of cartoons on children's minds and wellbeing. It has also a significant impact on the beliefs and values that children further develop over time.

Postman (1985) elaborated on how television has made multiple generations of children for whom television has been their first and most accessible teacher, for many of them a reliable companion and friend too. The author well argues that "television in its present state does not satisfy the conditions for honest intellectual involvement and rational argument".

Gonick (1997) puts light on a part of world history in order of occurrence through the seven part book series. The book series gives a point of view to the reader about the world happenings with detailed facts which are depicted in the form of cartoons. The book also explains about the motivations behind human

\footnotetext{
*Professor, School of Computer Engineering \& Technology, Dr. Vishwanath Karad MIT-WPU, Pune, India.

${ }^{ \pm}$Executive, HR \& Establishment Section, Dr. Vishwanath Karad MIT-WPU, Pune, India.
} 
discoveries, inventions, etc.; the editorial comments on these were very well received.

Williams (1990) study of television, first published in 1974, was way ahead of its time. It was responsible for introducing various ideas put forth by television, the full implications of which we are beginning to appreciate recently. The author argues with well reason that, television is part of the well woven fabric of our daily lives. The new technologies continue to put forth diverse opportunities, momentarily outside the control of international corporations or the grasp of media moguls, for new forms of self and political expression. The manipulative powers of television, or of its apparently inexhaustible appeal to children, react in ways which implicitly suppress all the other history of communication.

Lemish (2007) had put forth a comprehensive view on children and television. This is done based on examining the accumulated global literature in this field of the last 50 years. The author gives a balanced review to relate television in children's lives in their unique cultural spaces. It explains the universal understandings that hold true for children around the world. It elaborates well on the screen culture which children grow up these days and explains how the behavior of children is integrated with what they see on television. They also go on to report gender inequality both within the content children watch on television and behind the scenes in the industry where the content is created.

Lemish and Johnson (2019) in the technical report argue that television is a major socializing force in children's lives - they spend more time watching and interacting with screens than in any other activity and they learn from TV about societal values, who matters in society, what one can aspire to become etc. They report some key findings:

- There is considerable gap in the children's TV market for non-fiction content.

- There is little content on television for tweens.

- Over half of the characters in children's shows are non-human; children learn social behavior best from human-like characters (not talking animals).

The authors call for content creators to portray more diversity in their programming in order to better reflect the modern world which is growing increasingly more diverse.

Cartoons have many genres - action, romance, adventure, fantasy etc. Based on the age group of the characters cartoons portrayed in a particular series, they can be further classified.

As is the norm of most entertainment entities, the cost of creation of these cartoons is high, the success rate is relatively low, and it takes a long time for a character to get into the minds of the audience. It is observed that most cartoon films are short in duration, usually around 20-25 minutes per episode, as are seen on the TV channels.

During the duration of the episode, the characters have to be introduced, the stage of the episode is to be set, the story should be told and it should almost always finish with a happy ending with the protagonist winning over the antagonist, 
all under around 20 minutes, all done considering the attention span of children before they are distracted to something more attractive and engaging.

Various observations report that children below age 13 constitute $40 \%$ of the cartoon audience and the remaining $60 \%$ are the ones aged between 14 and 28 years, the tweens. This does not include the adults (aged above 28 years) who do watch cartoons with their children, but do not report.

Most cartoons depict the importance of team work. The characters are too small by age, by capability, by skills to achieve something significant; they overcome this shortcoming by applying teamwork.

Overall, there are a lot of parameters which go in to make the cartoon popular or successful. These attributes are to be dealt properly and correlated to each other to understand the role of each one of them.

\section{The Cartoon Films in India}

The Indian consumers of cartoons, largely children, primaries between age groups of early childhood till pre-teens, namely 2 years to 12 years, had to live with adapted cartoons from USA, Japan, Canada, etc. The successful cartoons films there were simply dubbed in Hindi and a few other regional languages for the consumer in India. The storylines of these were not Indian, neither were the characters, the cultures, the dressing, lifestyles etc.

It is a lot easier for broadcasters to acquire the rights to successfully running cartoons from overseas and dub them, rather than go through the entire exercise of creating new characters. Children are also generally less sensitive to social issues like the character's origin and looks than are the adults. The broadcasters pair up with local sound recording studios to generate voiceovers, in the national language and a few regional languages and launch these films in the Indian market. As the cartoons speak the local lingo and children's mother tongue languages they can easily connect with the kids here.

We had to live with these dubbed cartoons and had to wait till the beginning of the $20^{\text {th }}$ century to welcome the Made-in-India cartoons on our TV sets. The imagination of children can run wild, they have no barriers. Children never mind that the cartoons do not look like them, do not wear the same types of clothes, neither do they behave like their peers.

The earliest animation film telecast on national TV in India, Doordarshan, was Ek Anek Aur Ekta which was seven minutes long. It was followed by the first animated television series, Ghayab Aya.

Characters from Indian mythology abound in many of the Indian cartoons. The characters in mythology are strong and they are reflected in most of the cartoon characters inspired from mythology. Children should be shown the protagonist with whom they can relate to and can connect with, easily. Children aspire to be like the protagonist. They idealize the behavior and habits of these cartoon characters. The central plot usually is the winning of the good over the evil. 
The characters in most cartoon films all are also used for marketing, advertising and merchandising of children's products to ride on the success of the character. Items from compass box, water bottles, school bags, notepads, book covers, have these cartoon characters. Some schools have used these characters as their mascots to keep the children engaged.

\section{Methodology}

The work starts from identifying cartoon films which are popular in India. These cartoon films had quite a few entries which are of non-Indian origin but are dubbed in Indian languages to be launched in India for the local audience.

The primary focus of this study was to look at how the locally made cartoon films are doing in the Indian landscape. The central theme of the work lies in identifying what are the attributes /characteristics of the cartoon films which are prevalent and how do they affect the Indian children audience.

This was done by initially identifying the cartoon films which are made locally and are popular amongst children. This required collecting quantitative data of the cartoon films. An empirical study was planned for this. This led to short listing thirteen cartoon films for this study which are popular and successful.

Data about these thirteen was collected from the web portals of the cartoon channels to identify the production houses of the cartoon films. The production houses had most of the attribute data for each of the cartoon films. The details/ attributes which were to be considered for the study of the cartoon films were enlisted as part of primary data gathering activities.

Data was collected from various sources to collect producers, television ratings, cartoon character details, storylines, number of episodes, etc. Some data required for this study was not available at a single source. In such cases data was sourced from multiple sources.

The qualitative data of a cartoon film being popular was inferred with the logic that there is a direct co-relation of the number of times the cartoon is telecast on the cartoon television channel and also on the number of seasons and episodes which are made of the particular cartoon film. This approach is direct and the numbers are available and can be cross verified to be correct.

The television rating points of the cartoon films telecast on the cartoon channels are in sync with the observations of this study.

\section{The Indian Cartoons}

For this paper, the authors have considered the following cartoon films (Table 1). All of these are made in India and have a lot of features and depict cultures, storylines from the culture, and the rich mythology heritage of India. 
Table 1. Cartoon Films Considered

\begin{tabular}{|c|c|c|c|c|}
\hline $\begin{array}{l}\text { Sr. } \\
\text { No. }\end{array}$ & Cartoon Name & $\begin{array}{l}\text { Protagonist } \\
\text { Primary } \\
\text { Character } \\
\end{array}$ & $\begin{array}{l}\text { Special } \\
\text { Character }\end{array}$ & Other Characters (with Gender) \\
\hline 1 & $\begin{array}{l}\text { Bandbudh Aur } \\
\text { Budbak }\end{array}$ & $\begin{array}{c}\text { Badrinath (M) } \\
\text { Buddhadeb (M) }\end{array}$ & -- & $\begin{array}{c}\text { Dubey Sir (M), Rathi Sir (M), } \\
\text { Bindiya Roy (F), Jeeva (M), } \\
\text { Sabina (F), Gyan Singh (M), } \\
\text { Yogiraj Sir (M), Patel (M), Karan } \\
\text { (M) }\end{array}$ \\
\hline 2 & Chhota Bheem & $\begin{array}{l}\text { ChhotaBheem } \\
\text { (M) }\end{array}$ & $\begin{array}{l}\text { Jaggu }(\mathrm{M}) \\
\text { Monkey }\end{array}$ & $\begin{array}{c}\text { Chutki (F), Raju (M), Kalia (M), } \\
\text { Dholu (M), Bholu (M), } \\
\text { RajkumariIndumati (F), Raja } \\
\text { Indravarma (M) }\end{array}$ \\
\hline 3 & Kumbh Karan & $\begin{array}{l}\operatorname{Kumbh}(\mathrm{M}) \\
\operatorname{Karan}(\mathrm{M})\end{array}$ & $\begin{array}{l}\text { Kaddu (M) } \\
\text { Porcupine }\end{array}$ & $\begin{array}{c}\text { Tara (F), Sardar (M), Super } \\
\text { Chacha (M), DadiMaa (F), Kabira } \\
(\mathrm{M})\end{array}$ \\
\hline 4 & Motu Patlu & $\begin{array}{c}\text { Motu (M) Patlu } \\
(\mathrm{M})\end{array}$ & -- & $\begin{array}{c}\text { Dr. Jhatka (M), Ghasitaram (M), } \\
\text { Chingum (M) }\end{array}$ \\
\hline 5 & Roll No. 21 & Kris $(\mathrm{M})$ & -- & $\begin{array}{c}\text { Kanishk (M), Doctor J (M), Pinky } \\
\text { (F), Babloo (M), Madhu (F), Golu } \\
\text { (M), Sukhi (M), Taarak (M), } \\
\text { Suparna (F), Basu (M) }\end{array}$ \\
\hline 6 & $\begin{array}{l}\text { The Adventures } \\
\text { of Tenali Rama }\end{array}$ & Tenali (M) & -- & $\underset{(\mathrm{M})}{\operatorname{King}(\mathrm{M}), \underset{\mathrm{M}}{\text { Rajguru }(\mathrm{M}), \text { Tingary }}}$ \\
\hline 7 & Little Singham & $\begin{array}{l}\text { Little Singham } \\
\text { (M) }\end{array}$ & $\begin{array}{l}\text { Chikki (M) } \\
\text { Monkey }\end{array}$ & $\begin{array}{l}\text { Ajay (M), Babli (F), Hawaldar } \\
\text { karate (M), Professor Avishkar } \\
(\mathrm{M})\end{array}$ \\
\hline 8 & Mighty Raju & Raju (M) & $\begin{array}{c}\text { Cheeky }(\mathrm{M}) \\
\text { Monkey }\end{array}$ & $\begin{array}{l}\text { Sandhya (F), Swami (M), Moby } \\
(\mathrm{M}), \text { Commissioner Khanna (M) }\end{array}$ \\
\hline 9 & $\begin{array}{l}\text { ViR: The Robot } \\
\text { Boy }\end{array}$ & $\operatorname{Vir}(\mathrm{M})$ & $\begin{array}{c}\text { Chulbul (M) } \\
\text { Donkey }\end{array}$ & $\begin{array}{c}\text { Imli (F), Gintu (M), Principal Sir } \\
(\mathrm{M})\end{array}$ \\
\hline 10 & Chorr Police & $\begin{array}{c}\text { Inspector } \\
\text { Lovely Singh } \\
\text { (M) }\end{array}$ & -- & Anthony (M), Titli (F) \\
\hline 11 & Keymon Ache & $\begin{array}{l}\text { Keymon Ache } \\
(\mathrm{M})\end{array}$ & -- & $\begin{array}{c}\text { Rohan Tendulkar (M), Radha } \\
\text { Tendulkar (F) }\end{array}$ \\
\hline 12 & Little Krishna & Krishna (M) & -- & Balram (M), Radha $(\mathrm{F})$, \\
\hline 13 & Super V & Super V (M) & -- & \\
\hline
\end{tabular}

A brief narrative of the cartoon film and the primary characters in each cartoon film are depicted here. Apart from the depicted characters, there are many more which are seen in some or few cartoon films but are not seen as prominently as the ones depicted herein.

\section{Bandbudh Aur Budbak}

The plot of the cartoon depicts the tricks and school life of the two naughty friends, Badrinath and Buddhadev. The primary setting is in the school, where the two naughty protagonists certainly find themselves at the center of all trouble, usually getting off scot-free with sheer luck. It is full of whacky capers and whimsical antics (Table 2). 
Table 2. Primary Characters of Bandbudh Aur Budbak

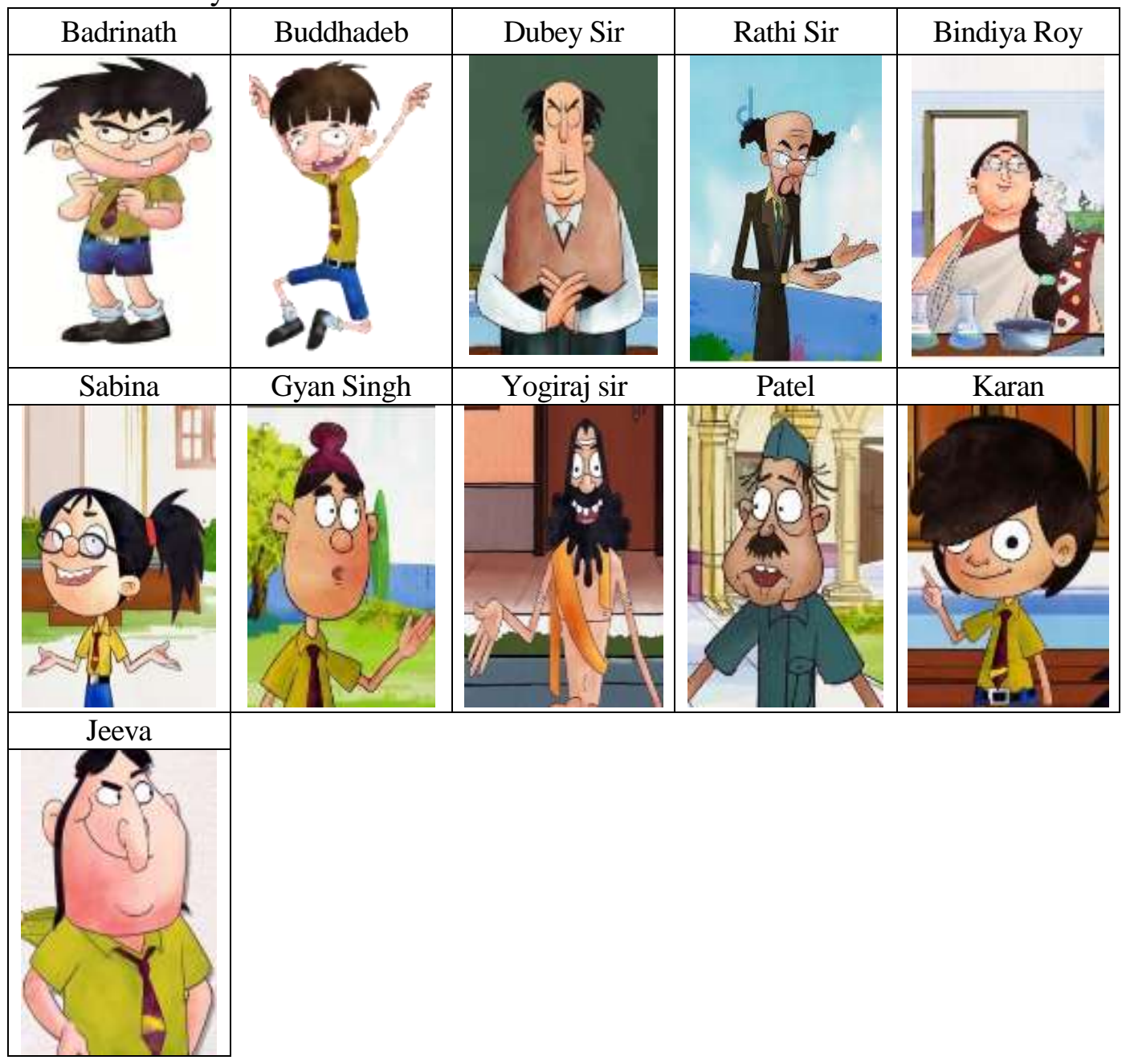

\section{Chhota Bheem}

The plot of the cartoon depicts Bheem, and is referred to as Chhota Bheem who is depicted as a 9 year old boy. Bheem is depicted as a strong, brave and intelligent child. The series is set in the fictional Kingdom of Dholakpur. Bheem's rival is the character Kalia. Kalia is depicted to be envious of Bheem's popularity. Kalia has two sidekicks, Dholu and Bholu who are twin brothers. The trios regularly plot to embarrass and defeat Bheem, but never succeed in these endeavours (Table 3). 
Table 3. Primary Characters of Choota Bheem

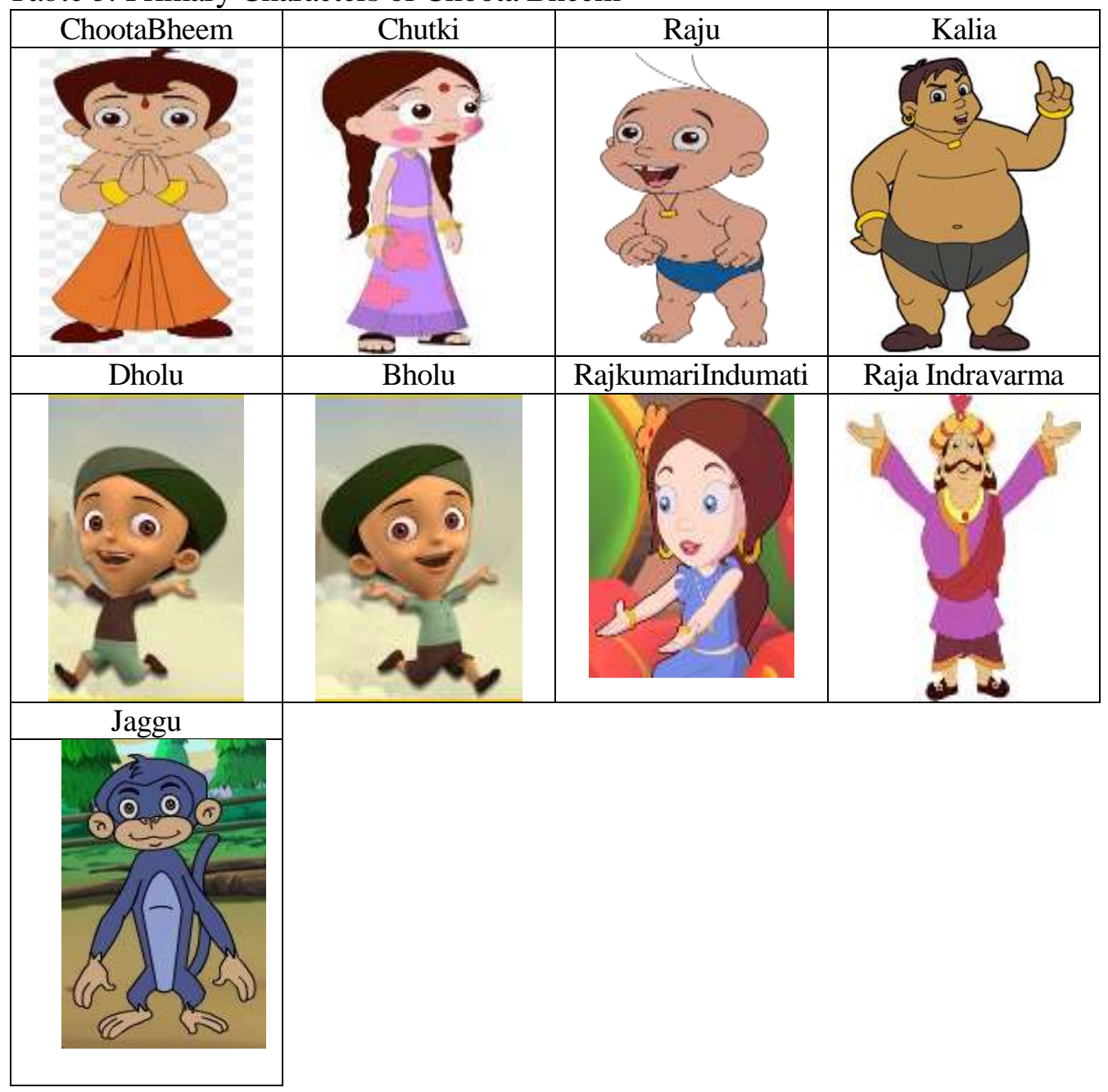

\section{Kumbh Karan}

The plot of the cartoon depicts the adventures of Kumbh and Karan. They are twin brothers residing in the small colony of Ajab-Gajabpur. Kumbh is depicted as a healthy, lazy, sleepy, and always hungry.Kumbh is strong with a soft heart. Karan on the other hand is an agile and sharp. Tara is their friend, and the two along with their pet porcupine Kaddu go on multiple quests (Table 4). 
Table 4. Primary Characters of Kumbh Karan

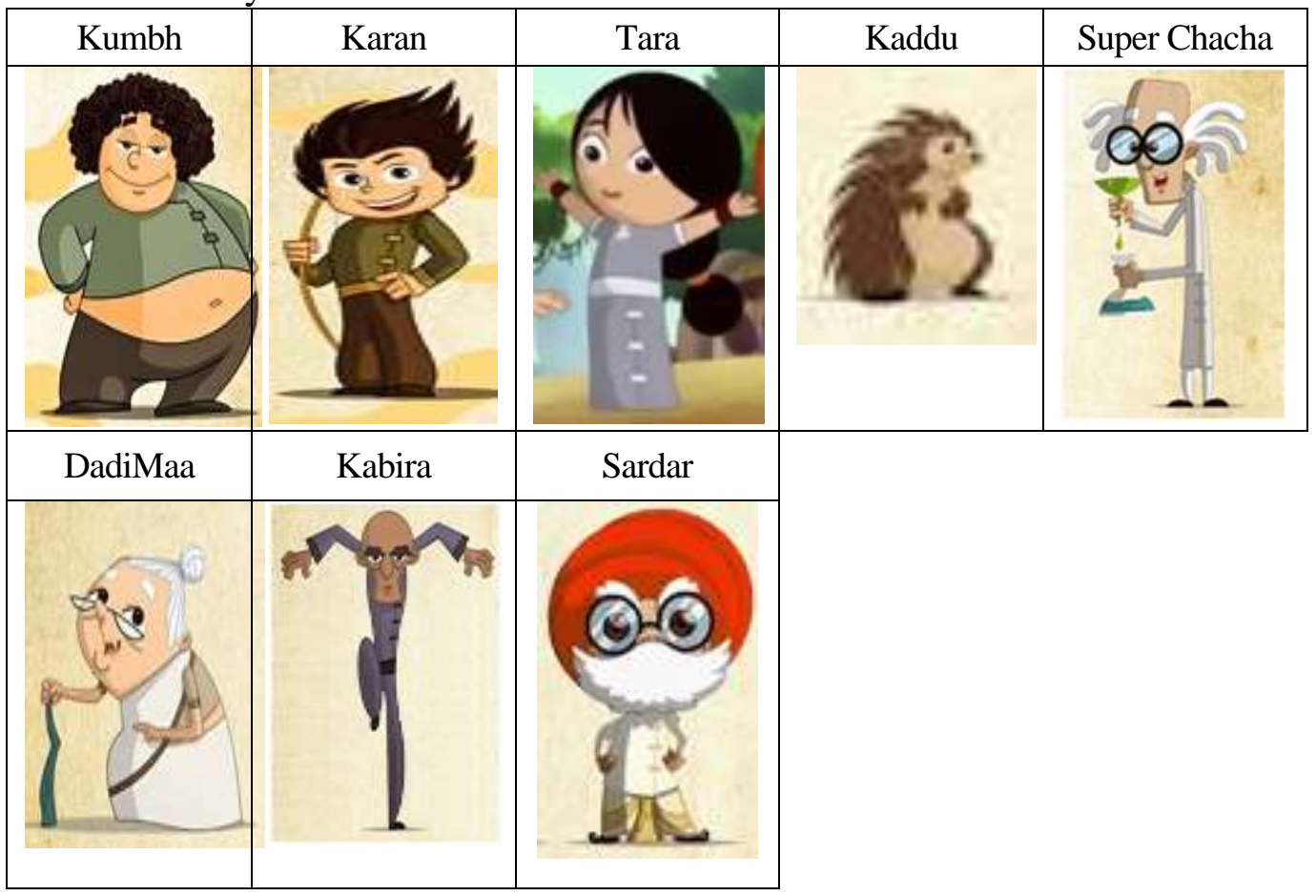

\section{Motu and Patlu}

The plot of the cartoon depicts the adventures of Motu and Patlu, who are two friends from a small town in India. The two usually invite trouble regularly and they get out of these situations in entertaining situations. The two always are by each other side in these ups and downs. Motu is depicted as a food addict. Patlu is the nuttier of the two (Table 5).

Table 5. Primary Characters of Motu and Patlu

\begin{tabular}{|c|c|c|c|c|}
\hline Motu & Patlu & Dr. Jhatka & Ghasitaram & Chingum \\
\hline 4 & &
\end{tabular}

\section{Roll No. 21}

The plot of the cartoon depicts a modern take on the rivalry between the reincarnations of Kris (Lord Krishna) and Kanishk (daemon Kansa). Kanishk is depicted as the crooked but smooth talking Principal of Anath Ashram, where they study. Kanishk tries to implement complete obedience of pupils in his school. Kris 
makes it difficult for Kanishk and for his fellow school mates. Kanishk calls various demons and monsters beat Kris. Kris defeats all the demons with his wit and mystical powers. Kanishk's attempts fail as Kris along with his friends tide though the troubles Kanishk has created for them (Table 6).

Table 6. Primary Characters of Roll No. 21

\begin{tabular}{|l|l|l|l|l|}
\hline Kris & Kanishk & Doctor J & Pinky & Babloo \\
\hline & & & & \\
\hline
\end{tabular}

\section{The Adventures of Tenali Raman}

The plot of the cartoon depicts the story of the poet Tenali Raman who is a legendary in the court of Emperor Krishnadevraya. Tenali Raman uses his timely wit and intelligence to solve problems and thus becomes popular in the King's court. His arch rivals try to humiliate him regularly but fail to do so. Tenali Rama also helps Emperor Krishnadevraya in saving Vijayanagar kingdom from various evil elements (Table 7).

Table 7. Primary Characters of the Adventures of Tenali Raman

\begin{tabular}{|c|c|c|c|}
\hline Tenali & King & Rajguru & Tingary \\
\hline & &
\end{tabular}




\section{Little Singham}

The plot of the cartoon depicts the life of Singham, who is depicted as a small boy, super cop, who fights criminals, monsters while trying to save his city. The show is loosely depicted from the film by the same name, Singham directed by Rohit Shetty, in the year 2011 (Table 8).

Table 8. Primary Characters of Little Singham

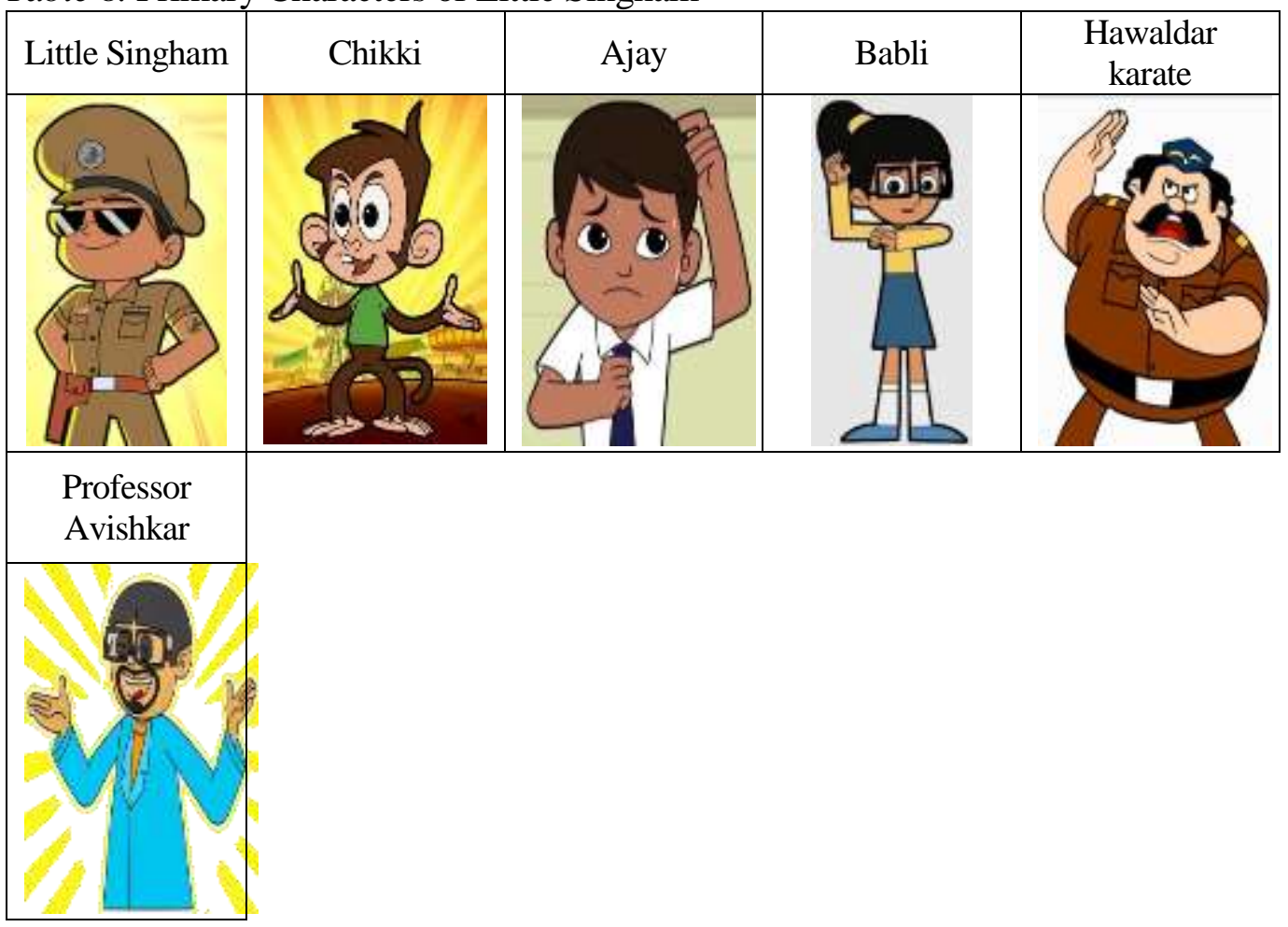

\section{Mighty Raju}

The plot of the cartoon depicts the adventures of a four year old boy, Raju based in the city of Aryanagar. Raju is intelligent with strong morals and has super-human strength. Raju is ready to risk his own safety while trying to save his city from the evil forces. Raju has received his super powers due to a chemical compound created by his father Swami, who is a scientist (Table 9). 
Table 9. Primary Characters of Mighty Raju

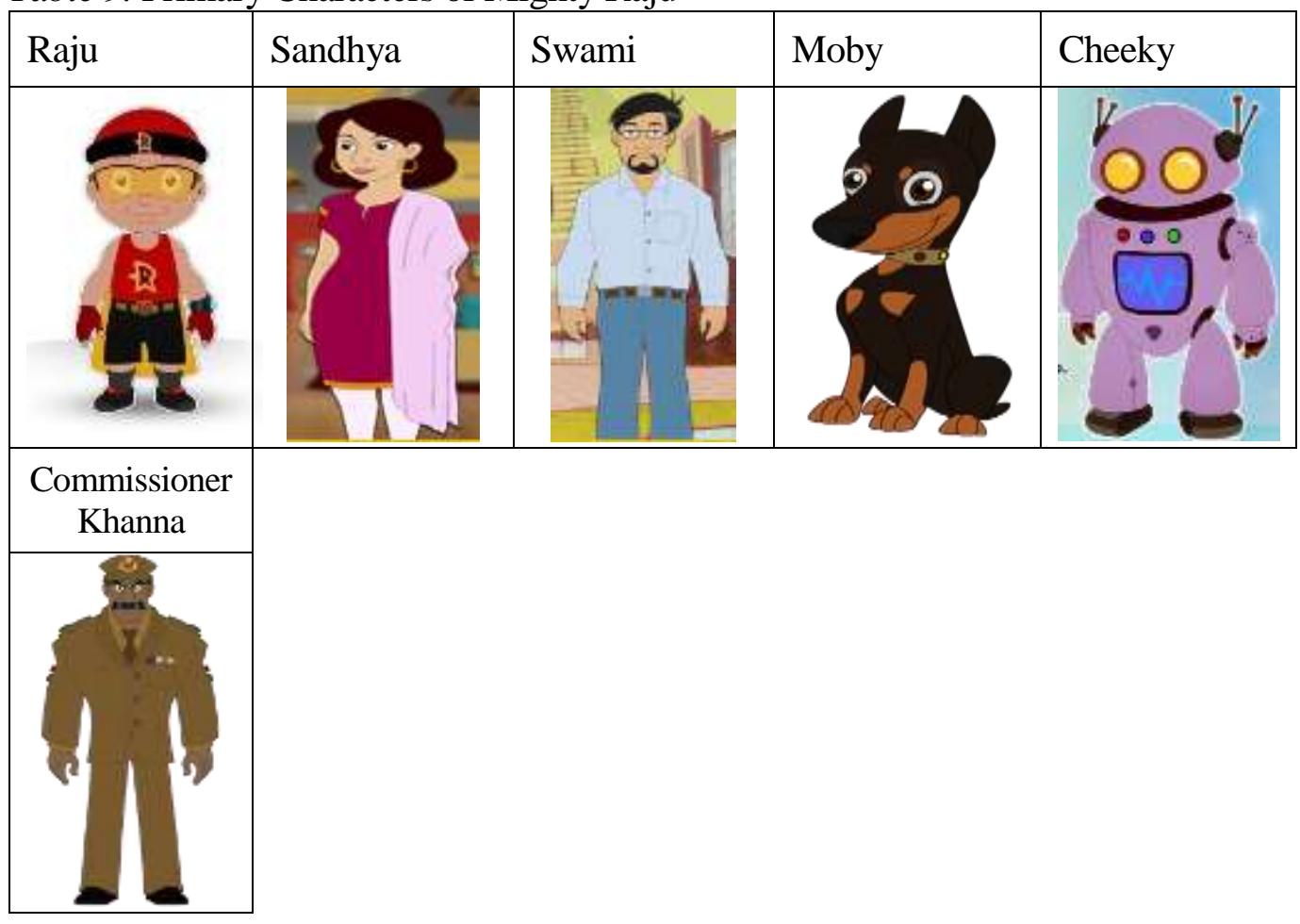

\section{ViR: The Robot Boy}

The plot of the cartoon depicts the humorous escapades of Vir which is a humanoid robot. A child with human-like qualities has emotions and with superhuman abilities. Vir the robot boy always helps other and tides through the problems along with his close friends. Vir manages to save all the fellow mates from trouble by using his quick thinking and with the help of his robotic abilities (Table 10).

Table 10. Primary Characters of Vir-The Robot Boy

\begin{tabular}{|c|c|c|c|c|}
\hline Vir & Imli & Gintu & Chulbul & Principal Sir \\
\hline & & & \\
\hline
\end{tabular}

\section{Chorr Police}

The plot of the cartoon depicts the robbery attempts of Anthony a clever thief who lives in the city slums. Anthony steals and distributes it to other people in the 
slums. He is portrayed as Robinhood by the slum dwellers. As Anthony goes about his job of stealing the police constable, Lovely Singh reaches the spot and tries to arrest him. This leads to some funny moments which are depicted in the cartoon films (Table 11).

Table 11. Primary Characters of Chorr Police

\begin{tabular}{|l|l|l|}
\hline Anthony & Inspector Lovely Singh & Titli \\
\hline
\end{tabular}

\section{Keymon Ache}

The plot of the cartoon depicts about the life of an ordinary boy, Rohan, who has a magical school bag named Keymon. The magical school bag can talk to and enchant other toys and make them do what he wants (Table 12).

Table 12. Primary Characters of Kemon Ache

\begin{tabular}{|l|l|l|}
\hline Keymon Ache & Rohan Tendulkar & RadhaTendulkar \\
\hline
\end{tabular}

\section{Little Krishna}

The plot of the cartoon depicts the nonstop pranks and mischief of Little Krishna who is the darling of Vrindavan. The kingdom is constantly under threat from the evil activities of king Kamsa. Krishna is depicted to be living a mischievous life and has many pranks on his friends and his fellow residents. Kamsa is restless as his evil activities are retaliated by Krishna along with his friends as are depicted in the cartoon films (Table 13). 
Table 13. Primary Characters of Little Krishna

\begin{tabular}{|c|c|c|c|}
\hline Krishna & Balram & Radha & Kamsa \\
\hline & 20 & & \\
\hline
\end{tabular}

\section{Super V}

The plot of the cartoon depicts the life of a character Super V, loosely based on ViratKohli. Super V becomes a superhero. He is trying to have a balance between his own aspirations, his father's expectations from him; he is shown fighting the evil forces (Table 14).

\section{Table 14. Primary Characters of Super V}

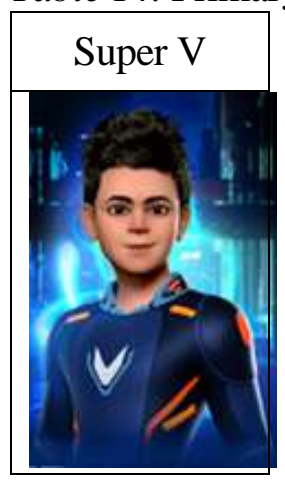

\section{Characteristics of the Indian Cartoons}

These cartoon films can be characterized based on the following details.

\section{The Age of the Protagonist}

It plays an important role in the cartoons films. If the age group of the protagonist is similar to the age of the audience, primarily children, there is a higher chance of engagement with the audience.

For the thirteen cartoon films under consideration, the age of the protagonist is as indicated in Figure 1. The youngest is the character in Mighty Raju at age 4 years, and the eldest of the cartoon character is 30 years old, the character in Tenali Rama. 
Figure 1. The Age of the Protagonist

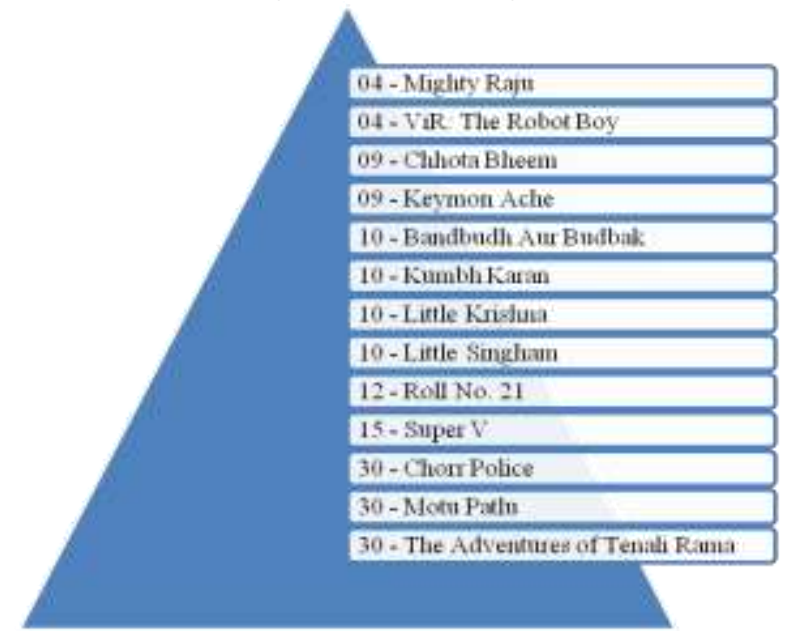

\section{The Number of Shows/Episodes}

The number of shows/episodes of the cartoon also plays a significant role in the popularity of the cartoon film, which depicts the popularity of the cartoon film. The number of episodes indicate the popularity of the cartoon film and the need felt by the production house to prepare more films portraying more stories thus keeping the cartoon franchise running. It also helps in adding more content leads to wider choice to the audience.

As children often watch the same cartoon multiple times, the chance of the same shows/episodes being repeated decreases in proportion to number of shows/ episodes of the particular cartoon.

For the thirteen cartoon films under consideration, the numbers of shows/ episodes of each particular cartoon are as indicated in Figure 2. The minimum of episodes are for the cartoon Super V at 12 shows and the highest number of episodes for Chhota Bheem at 624 shows.

Figure 2. The Number of Shows/Episodes

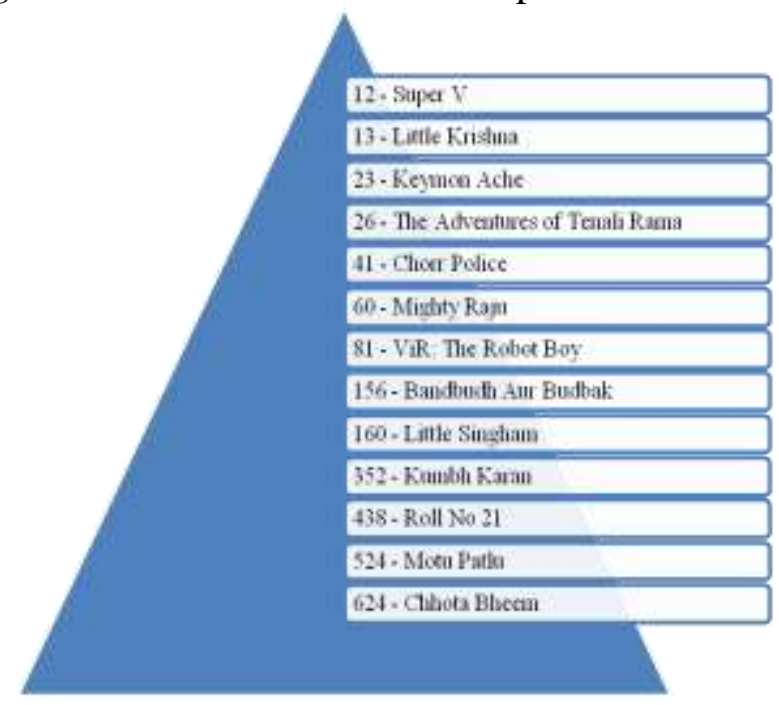


The percentage share of the episodes of these cartoon films are as depicted in Figure 3. The majority share is by cartoon films Chhota Bheem at 25\%, Motu Patlu at 20\%, Roll Number 21 at $17 \%$ and so on. These cartoon films seem to have grown in popularity over time and thus the increase in the number of shows which the production houses have prepared and telecast.

Figure 3. The Percentage Share of the Number of Shows/Episodes

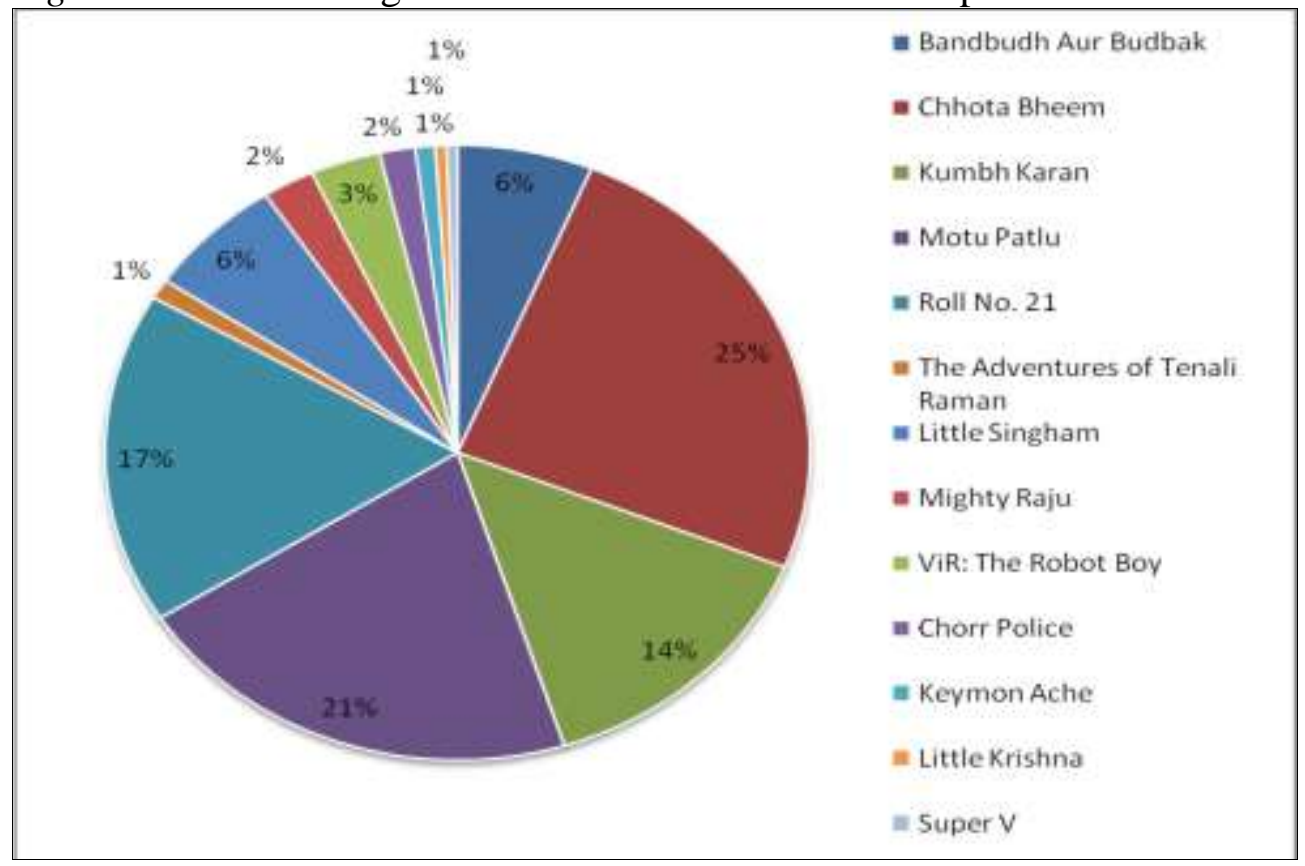

\section{The Year since Going Live on TV}

The year since going live on TV also implies the time that the cartoon has been available for the children to watch. The number of years since the cartoon was launched to the latest episode added to the franchise depicts the continued support from the audience and the sustained popularity leading to the cartoon being aired on TV for years together.

The time from launch till now has seen some cartoons being launched is a season by season manner while some are just launched for special occasions / some celebrating particular festivals, cultures, traditions followed in India.

For the thirteen cartoon films under consideration, the date of launch and the order in which they were launched on TV is as indicated in Figure 4. The earliest cartoon to be launched was The Adventures of Tenali Rama, way back in 2003, to the latest one to be launched, Super V in the year 2019. 
Figure 4. The Timeline of Years since Going Live on TV

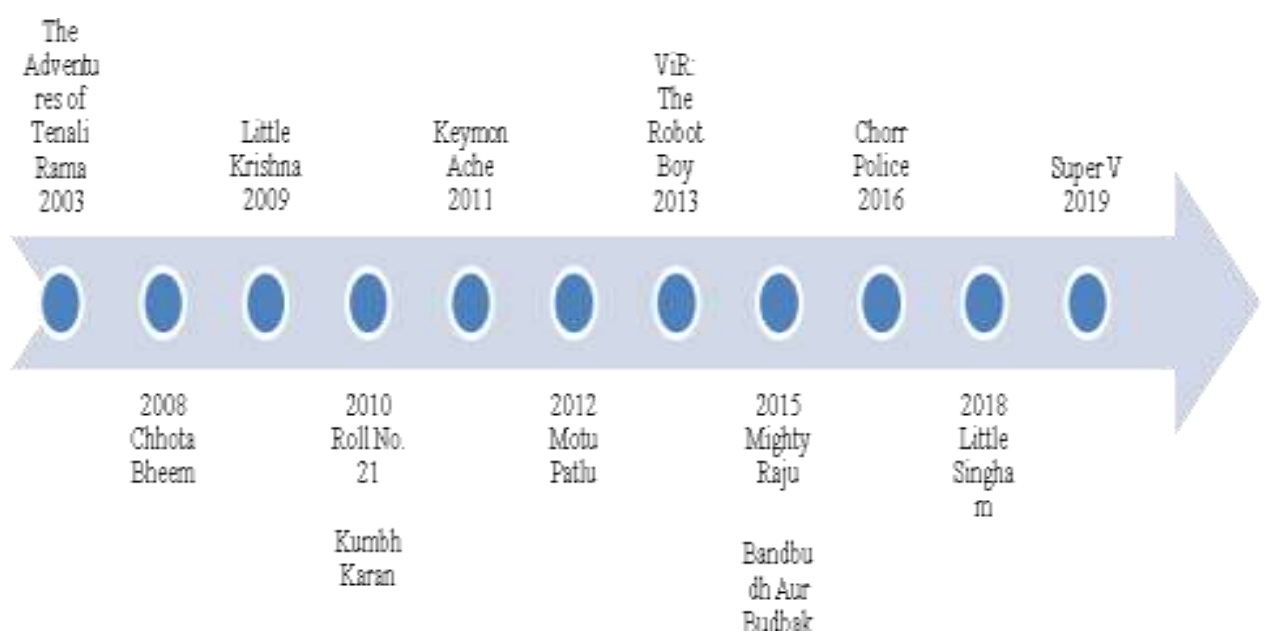

\section{The Locale of where the Cartoon Film is Based}

The locale of where the cartoon is based is also analysed. The scope of the characters behavior and the setup in which the cartoon characters operate are related accordingly. It is said that India resides in its towns and villages, that is the density of population is large therein. The audience in these locales can better connect to cartoon films if the setting of the cartoon is in an environment that they can relate to. A good number of cartoons are based in villages and towns.

For the thirteen cartoon films under consideration, the locale of the cartoon is as indicated in Figure 5. They can be classified into four categories, based in a kingdom, in a city, in a small town or in schools.

Figure 5. The Locale of the Cartoon Film

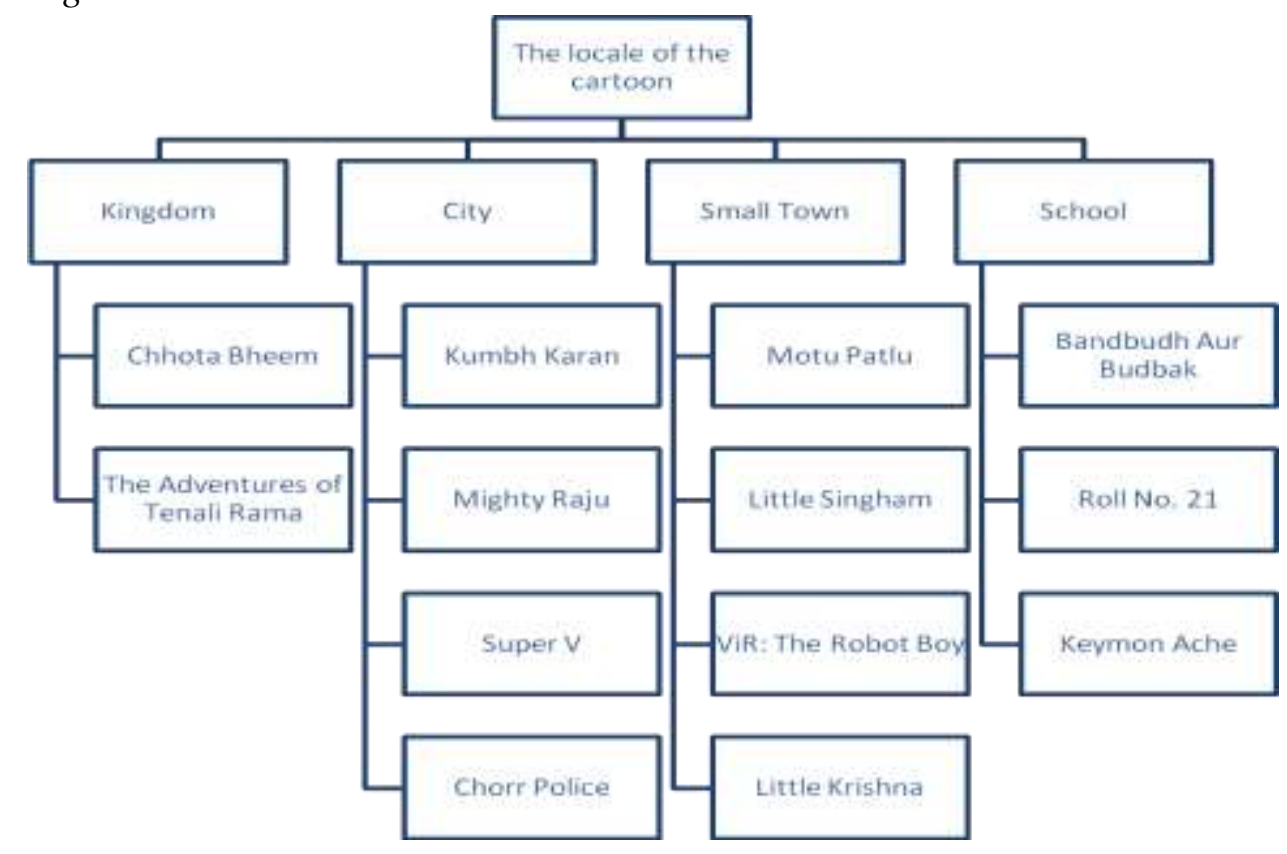




\section{The TV Channel on which the Cartoon Plays}

The TV channel on which the cartoon plays is considered. The successful ones generate a lot of revenue for the particular channel and also increase the viewership considerably. Based on the viewership cartoons also are telecast at prime time from the children perspective, when they are at home, back from school, etc.

For the thirteen cartoon films under consideration, the channels on which they are telecast are as depicted in Figure 6. Channels like, Cartoon Network, Pogo, Nickelodeon telecast the most popular cartoon films.

It is also speculated that these flagship cartoon films are the key to the popularity of these TV channels. Children are hooked on to the channels and the cartoon films telecast therein. They co-relate the channels with the cartoon films which leads to the success of the TV channels too.

Figure 6. The TV Channels on which the Cartoon Plays

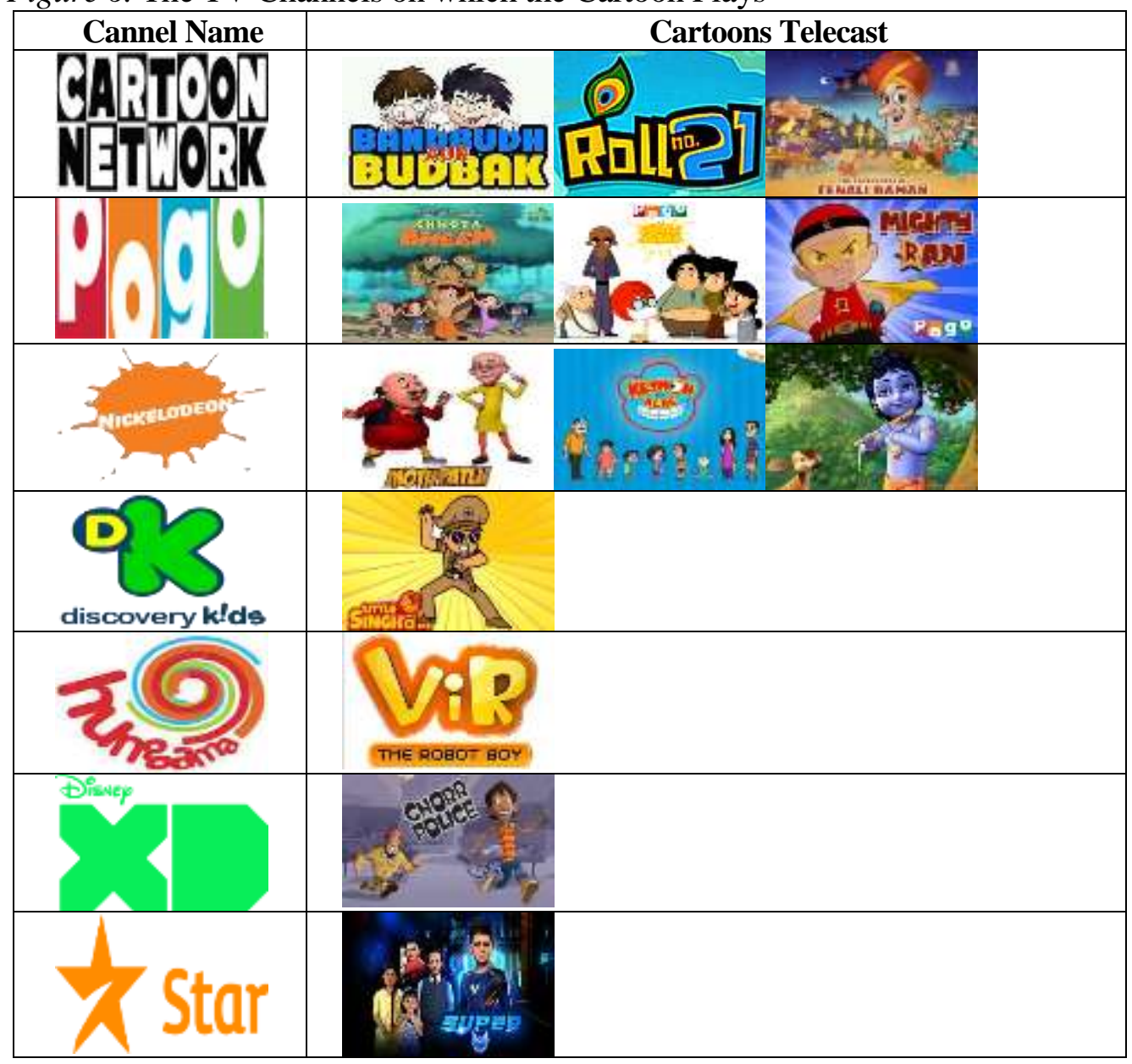




\section{The Number of Characters in the Cartoon Film}

The number of characters in the cartoon film is also considered. These films usually have the same characters in most of the episodes. Films with more characters are observed to have more episodes as the producers can relate multiple episodes to various characters.

For the thirteen cartoon films under consideration, the number of characters average to around 6, with cartoon films like, Bandbudh Aur Budbak, Roll No. 21, starring around 10+ characters is most episodes to Super V which depicts only the protagonist primarily and usually in isolation.

Figure 7. The Number of Characters in the Cartoon Film

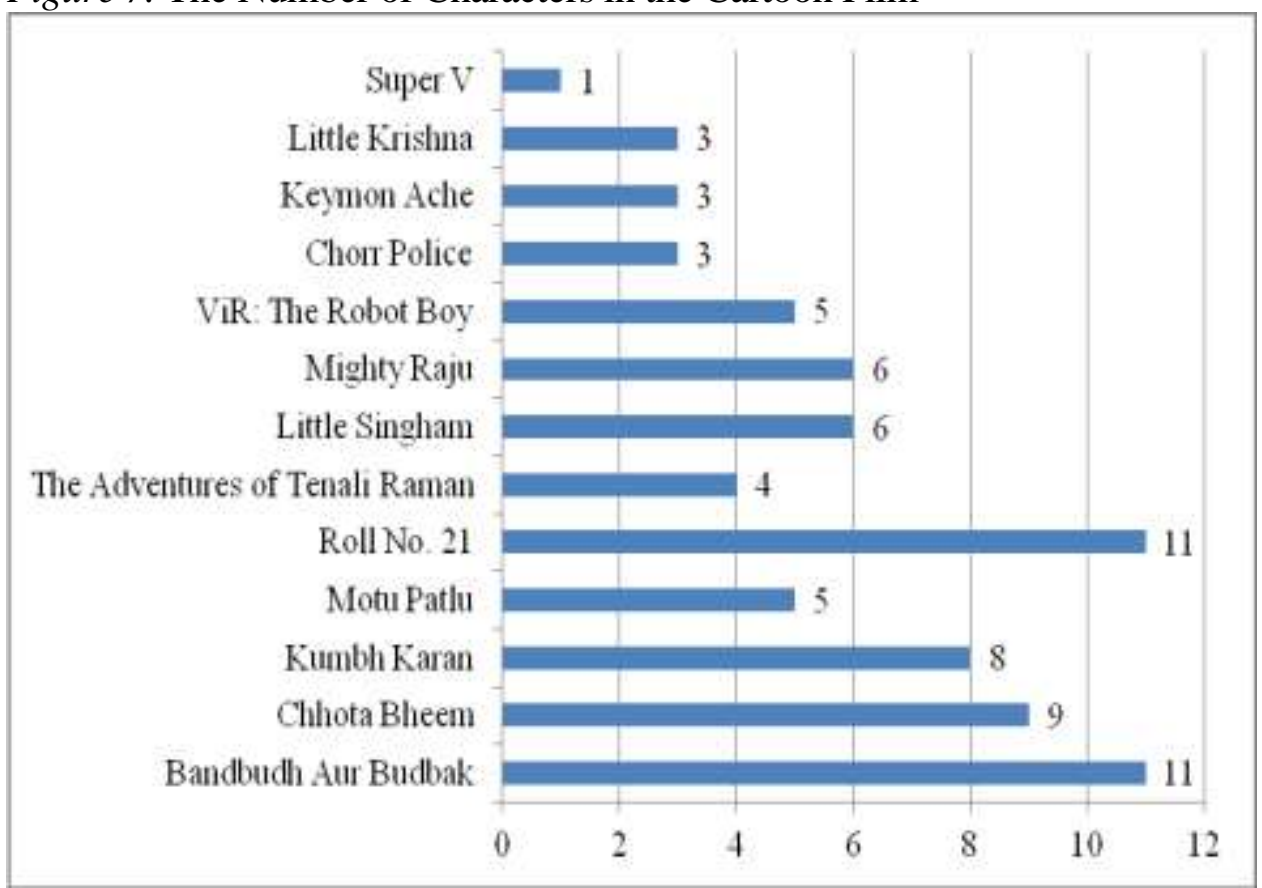

\section{The Number of Characters vis-à-vis the Number of Episodes}

The number of characters in the cartoon film vis-à-vis the number of episodes in the cartoon film are co-related. It is evident that the number of episodes of the cartoon film is nearly directly proportional to the number of characters in the cartoon film.

For the thirteen cartoon films under consideration, the numbers of characters and the number of episodes, telecast on TV, of the cartoon films seem to directly correlate. Chhota Bheem leads with the largest number of episodes and is in the top 3 as regards the number of characters in the cartoon film (Figure 8).

Films with less than 5 characters are observed to have fewer numbers of episodes while for films with has 5 or more characters the number of episodes of the film seems to increases. Films which have more than 8 characters are observed to have a large number of episodes as compared to the rest with a multiple of hundreds. 
Figure 8. The Number of Characters in the Cartoon Film v/s the Number of Episodes

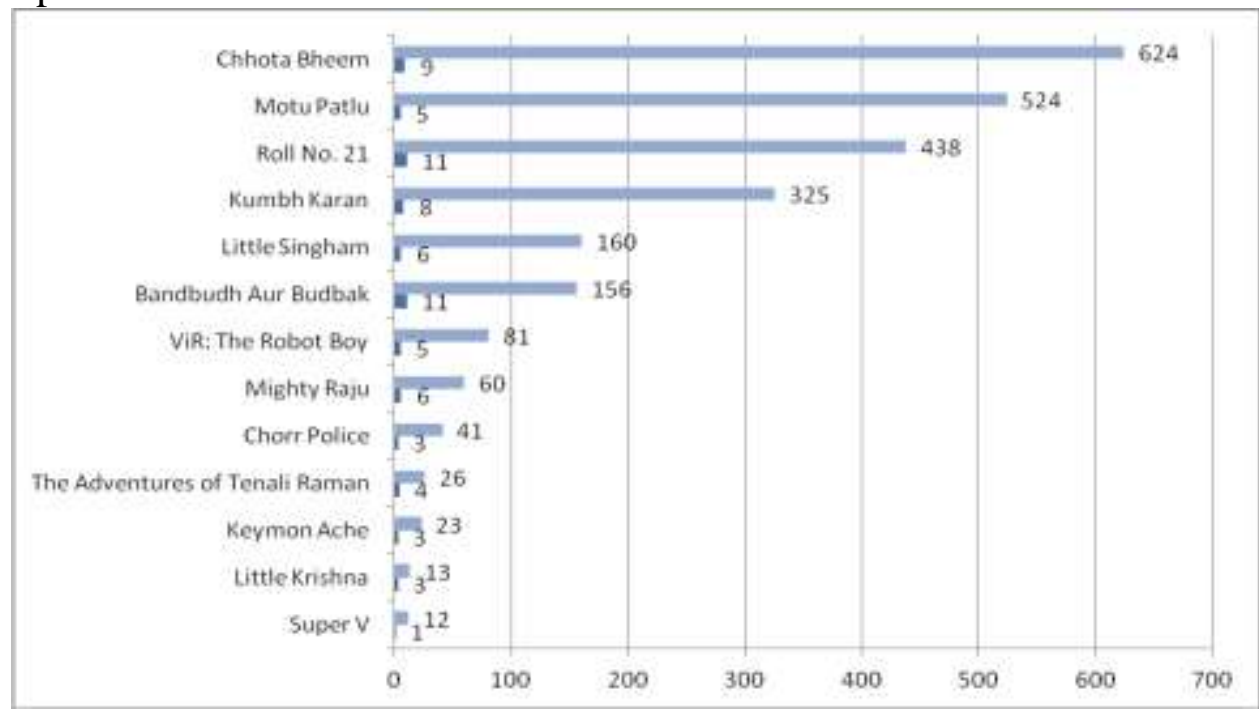

\section{The Gender Ratio in Indian Cartoon Films}

The protagonists in most of the cartoon programs are males. The ratio of male protagonist's verses female protagonist's is highly skewed and include towards the male characters. Most research about gender ratios of children's cartoons over the world, reported that there were $75 \%$ of characters being male and $21 \%$ female. Most of the cartoon films depict gender ratio biased in favor of the male gender.

Boshoff (2013) reports the research findings based on television content of 24 countries, and reveal a lot of gender bias in children's television.

As per 2015 consolidated census data, the gender ratio in India for males to females is 51:49. For the characters of Indian cartoon films, the ratio of males: females are skewed at 81:19. The details of the same are as depicted in Figure 9.

Figure 9. The Number of Male v/s Female Characters

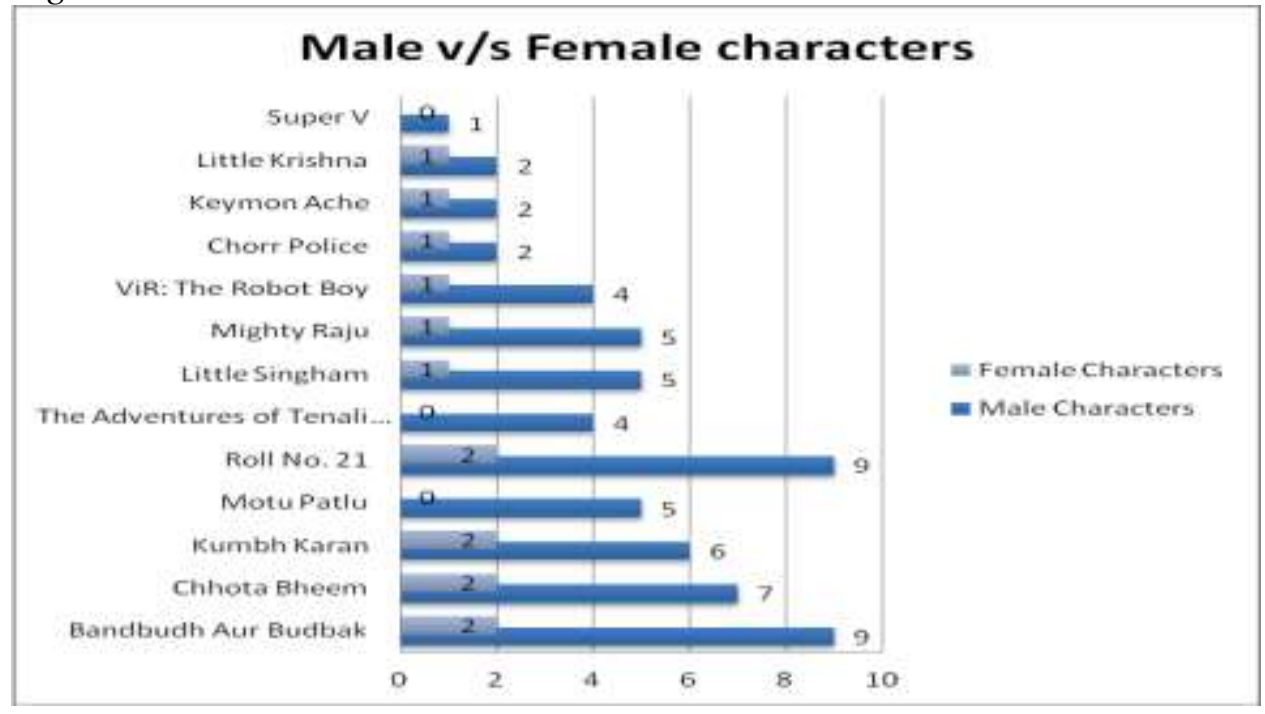




\section{Why no Super (S)heroes?}

Most cartoons have superheroes, but no super(s)heroes, cartoons in which the female gender is the protagonist. Desai (2019) have taken the example of Chhota Bheem to highlight the case in concern about super-she-roes. They go on to report that there is a positive change in the sense that these days many publishers, are working on stories, in which girls are seen as being strong, having a lot of fun and doing whatever they want.

It is expected that this study enables content creators of cartoons and the heads of channel content programming to work towards ensuring more suitable representations of gender in cartoon films. This will, in the long run, facilitate programming which is gender balanced.

\section{Indian Mythology and the Cartoons Films}

India has a rich culture and stories in mythology abound. A few of the most prominent ones are listed in Table 17.

Table 17. Mythology Stories with their Primary Characters

\begin{tabular}{|c|c|c|c|c|}
\hline $\begin{array}{c}\text { Sr. } \\
\text { No. }\end{array}$ & $\begin{array}{c}\text { Mythology } \\
\text { name }\end{array}$ & $\begin{array}{c}\text { Protagonist } \\
\text { Primary } \\
\text { Character }\end{array}$ & $\begin{array}{c}\text { Special } \\
\text { Character }\end{array}$ & $\begin{array}{c}\text { Other characters (With } \\
\text { Gender) }\end{array}$ \\
\hline 1 & Ramayan & Ram (M) & $\begin{array}{c}\text { Hanuman (The } \\
\text { monkey god) }\end{array}$ & $\begin{array}{c}\text { Sita(F), Laxman (M), Bharat } \\
(\mathrm{M}), \text { Shatrughan (M), Ravan } \\
(\mathrm{M})\end{array}$ \\
\hline 2 & Mahabharat & Arjun (M) & Krishna & $\begin{array}{c}\text { Yudhishthir (M), Bhim (M), } \\
\text { Nakul (M), Sahadev (M), } \\
\text { Draupadi (M), Bheeshma } \\
(\mathrm{M}), \text { Karna (M) }\end{array}$ \\
\hline 3 & Krishna & Krishna (M) & Cow & $\begin{array}{c}\text { Balram (M), Yashoda (F), } \\
\text { Vasudev (M), Kans (M), } \\
\text { Sudama (M), Radha (F), } \\
\text { Rukmini (F) }\end{array}$ \\
\hline
\end{tabular}

The cartoon films analysed here seem to have a lot of correspondence with the mythological stories. Many a cartoon protagonists are inspired from the characters in Indian mythology. The analogy between the mythology stories and the ones depicted in the cartoon films seem to correlate too.

Cartoon films based on mythology are very much on the cards with a few being announced by production houses. These mythologies abound with mini stories, which make them an ideal candidate to be picturised and depicted well in the duration of the cartoon film. The stories in mythology are well known to the population at large and the audience can thus connect with these cartoons very easily. This leads to increases in its popularity and the success of the cartoon films. 


\section{Cartoon Films and Animals}

Humans are living with animals from the begging of the civilization. Animals are a part in a large number of households and are considered a part of the family too. They are an integral part of the day to day activities of the family.

Apart from the human characters the next predominant character depicted in cartoon films are animals, well preceded over birds, amphibians, insects, etc. Most of the popular cartoon films have animals shown besides them. Animals form an integral part of the films story, its picturisation, its success too.

Sarzynski (2018) from a designer / developers perspective, creating human character is difficult. To create animals, the designer needs to have access to a spectrum of shapes, colors and textures. Animal characters are easier to manage when you design your characters. Cartoon creators use the general culture and ideas that people have about animals, for example a cat trying to catch a mouse. Doing these things with real humans would be very difficult, but with animals it looks cute and funny.

Cartoon films, across the world have depicted a multitude of animals as central characters namely - Fishes, Cats, Dogs, Mouse, Duck, Squirrels, Bear, Canary, Pig, Wolf, Frog, Parrott, Chicken, etc. (Table 15).

Table 15. Cartoons with Primary Animal Characters

\begin{tabular}{|c|c|c|c|}
\hline $\begin{array}{l}\text { Cartoons with } \\
\text { Primary } \\
\text { character }\end{array}$ & \multicolumn{3}{|c|}{ Cartoon Film names } \\
\hline Fish & $\begin{array}{l}\text { - Finding Dory } \\
\text { - Finding Nemo } \\
\text { - SpongeBob } \\
\text { SquarePants } \\
\text { - Izzie's Way Home }\end{array}$ & $\begin{array}{l}\text { - Help I am a Fish } \\
\text { - Shark Tale } \\
\text { - The Little Mermaid } \\
\text { - Sharky\& George }\end{array}$ & $\begin{array}{l}\text { - The Fishing } \\
\text { Bear Back to the } \\
\text { Sea }\end{array}$ \\
\hline Cats & $\begin{array}{l}\text { - Garfield and friends } \\
\text { - Tom and Jerry } \\
\text { - Sylvester the Cat } \\
\text { - Felix the Cat }\end{array}$ & $\begin{array}{l}\text { - Calvin and Hobbes } \\
\text { - Pepé Le Pew } \\
\text { - Pink Panther } \\
\text { - The Lion King }\end{array}$ & - Heathcliff \\
\hline Dogs & $\begin{array}{l}\text { - Garfield and friends } \\
\text { - Droopy } \\
\text { - Family Guy } \\
\text { - Mickey Mouse }\end{array}$ & $\begin{array}{l}\text { - Peanuts } \\
\text { - Wacky Races } \\
\text { - The Jetsons } \\
\text { - Isle of Dogs } \\
\end{array}$ & $\begin{array}{l}\text { - Scooby-Doo } \\
\text { - Courage the } \\
\text { Cowardly Dog }\end{array}$ \\
\hline Pigs & $\begin{array}{l}\text { - Porky's Duck Hunt } \\
\text { - Babe } \\
\text { - Three Little Pigs } \\
\text { - Winnie-the-Pooh }\end{array}$ & $\begin{array}{l}\text { - Looney Tunes } \\
\text { - Timon and Pumbaa } \\
\text { - Animal Farm }\end{array}$ & \\
\hline Mouse & $\begin{array}{l}\text { - Mickey Mouse } \\
\text { - The Simpsons } \\
\text { - The Lion King } \\
\text { - Tom and Jerry }\end{array}$ & $\begin{array}{l}\text { - Alice in } \\
\text { Wonderland } \\
\text { - Cinderella } \\
\text { - Mighty Mouse }\end{array}$ & - Shrek \\
\hline
\end{tabular}




\begin{tabular}{|c|c|c|}
\hline & & - Ratatouille \\
\hline Duck & $\begin{array}{l}\text { - Donald Duck } \\
\text { - Duck Duck Goose } \\
\text { - Howard the Duck } \\
\text { - Ducktales }\end{array}$ & $\begin{array}{l}\text { - The Yogi Bear } \\
\text { Show } \\
\text { - Daffy Duck }\end{array}$ \\
\hline Bear & $\begin{array}{l}\text { - Winnie-the-Pooh } \\
\text { - The Yogi Bear Show } \\
\text { - The Jungle Book } \\
\text { - Adventures } \\
\text { Mowgli }\end{array}$ & $\begin{array}{l}\text { - Arctic Tale } \\
\text { - The Bear } \\
\text { - Grizzy and the } \\
\text { Lemmings }\end{array}$ \\
\hline Wolf & $\begin{array}{l}\text { - Hare and Wolf } \\
\text { - Blitz Wolf }\end{array}$ & \\
\hline
\end{tabular}

Five of the thirteen cartoon films considered in this work have animals in primary/supporting roles. In the Indian cartoon films, the animals depicted are very few, as indicated in Table 16.

Table 16. Cartoons with Primary Character Animals in Indian Cartoon Films

\begin{tabular}{|c|c|}
\hline Animal Character & Character name (Cartoon film name) \\
\hline Monkey & $\begin{array}{ll}\text { - } & \text { Jaggu (ChhotaBheem) } \\
\text { - } & \text { Chikki (Little Singham) } \\
\text { - } & \text { Cheeky (Mighty Raju) } \\
\end{array}$ \\
\hline Donkey & - Chulbul (ViR: The Robot Boy) \\
\hline Porcupine & - $\quad$ Kaddu (Kumbh Karan) \\
\hline
\end{tabular}

\section{Role of Animals in Children Lives}

People have lived in close proximity of animals all through human history. Archaeological excavations, of prehistoric settlements have unearthed a lot of depictions of direct Human Animal Interaction (HAI). The importance of animals in early humans and the interactions thereof are well elaborated by Curtis (2006). Depictions of animals are found in many of the earliest art forms too.

During times of the Neanderthals, tools and weapons were made from animal bones, dresses were made from skins, and the early humans adorned themselves with jewelry made from parts of animal bones and teeth. Some types of animals were domesticated and trained to serve as human companions. Some animals became pets some as means of affection. The earliest evidence of the existence of pets living closely with humans is reported from ancient Egypt, where various animals were usually embalmed and put in the tombs with their masters.

News reports claim that pets are a part of around $60 \%$ of American households. In homes with children the number increases to around $70 \%$. Tardif et al. (2008) elaborate that children pay close attention to pet animals, as evident by the fact the words in infants' early vocabularies are "cat", "dog", the family pets. Many children tend to develop intimate relationships with their family pets.

Deloache et al. (2011) report about the results of their experiments conducted with children and their visual attention towards animals. In terms of visual 
attention and emotional engagement, children tend to respond to a range of nonhuman animals than to various inanimate entities. Another key result was that, overall, the children gave more attention to animated animals than real animals. Their research supports an intrinsic tendency of humans to orient preferentially towards animals.

We all understand the benefits of properly made animations, which give illusion of life to otherwise inanimate objects. Particular work done with children that infants prefer animals to objects on the basis of both dynamic and static features, even when the entity is actually not an animal but rather an inanimate object which is made to look like an animal.

There is overwhelming presence of fairytales, fables and storybooks, associated with children which are either about animals or feature animals as an important central character in the storyline. Animals also are a dominant character in TV programs, especially those produced for younger children, namely cartoon films.

Real animals occupy an important role in children's world. Nearly all children enjoy visiting aquariums zoos, aquariums etc. Documentary films about nature and animals fascinate most children, and long to have companion pet animals.

Serpell (1999) have reported that households with children have higher rate of pet ownership. Various studies suggest that around $90 \%$ of children, would like to have a pet if given a choice. Karpyn et al. (2016) in their work highlight the constructive impact of cartoons with animals on children's selection of fruit and snacks. The results of their work suggest the potential for using animals in cartoons to encourage fruit and vegetable selection for children.

Quantitatively the study demonstrated that children were $66 \%$ as much more likely to select a healthy snack when an animal cartoon was displayed in association with the product. These results indicate that the efforts and revenue put in towards public health look to increase the appeal of fruits and vegetables as healthy snacks to children should consider use of animals in cartoons as part of their marketing strategies.

Sultana (2014) through the survey and interviews have reported the results, of the work done in Bangladesh, both positive and negative results that cartoons have on all ages people. Parents should avoid cartoons with violence which can be unsuitable for their children. They should make sure whether the cartoon film is appropriate for the age of the child. If there is a scene of violence or any disturbing scene in the cartoon that makes the child uneasy, the parents should explain the scene to the child in an appropriate way so that the child can only take the fun, not the detrimental message from that cartoon film.

Aliyeva (2013) have highlighted that in many cartoons the characters are shown jumping, diving, and falling from heights and then landing safely and easily without any harm. Cartoon characters however always tend survive these falls without any injury, which is an unrealistic message conveyed to children. The children audience may believe that when someone is hurt, falls or jumps, he or she would remain unharmed. It reduces the child's sensitivity to violence and to children or people who are victims of violence. It also leads to an increase in their craving for more violence in media and so too in real life. Cartoon violence is 
essentially damaging to the children in the long run because children often cannot tell the difference between real life and fiction.

\section{Why do Cartoon Characters Have Four Fingers? - A Designer's Perspective?}

Many viewers might have not noticed that cartoon characters usually sport only four fingers on their hands. But once it is understood, it becomes evident all over in most of the cartoon characters, especially the human characters. There is no clearly specified basis for why cartoons have four fingers. As indicted in literature, there are some very good reasons for it, which date back to the good old days of early animation.

Before computers were used in making animated cartoons, artists drew cartoons by hand. Hands and fingers are the hardest part of the body to draw. Drawing hands with five fingers v/s drawing hands with four fingers identical in shape and size speeds up the creative process by 20\%. Adetula(2017) well explains by sketching characters with only four digits, it saved time and money per character. It also implies fewer fingers to animate. Cartoon character having only four fingers does not affect the depiction or behavior of the cartoon character nor the story line.

Walt Disney once said, "Using five fingers would have made Mickey's hands look like a bunch of bananas".

\section{Discussion}

There are analogies between the cartoons are reported in this paper. Some cartoon films like, Chhota Bheem, Kumbh Karan, Roll No. 21, Little Krishna are based on the prominent characters from mythology which are well known to the general population and tightly ingrained in the Indian literature, folklores and common wisdom transferred from the older generation to the younger generation in the form of stories and lullabies.

Some cartoon films like, Mighty Raju, ViR: The Robot Boy, Chorr Police, Keymon Ache, Super V are based on the super hero concept of the cartoon character having super powers and their fight against the evil forces of the day with the help of these super powers. The age of the cartoon character although tender but the protagonist is mature enough as originated by their super powers and them taking on evil forces of higher age and larger number of side-kicks accompanying them.

The cartoon film Bandbudh Aur Budbak is based on the naughty students in school. These characters are evident in most primary schools what we all have attended and well depict the hidden desires of playing tantrums while in school, which the common student could not do during his study years.

Motu Patlu and Little Singham fight for the welfare of their small towns. They are happy go lucky characters with a kind heart and larger social commitment 
to the welfare of the society in which they dwell. These small towns are the targets of the evil forces which play havoc in the towns and the cartoon characters retaliate these evil forces thus saving the day.

The locales of these cartoons are an important feature to be noted. Children connect well with their peers, similar in age group and with common upbringing while in schools. Some cartoons are totally based in school settings like Bandbudh Aur Budbak, Keymon Ache, Kumbh Karan, etc.

It is said India resides in its towns and villages, a large part of the audience of these cartoon films, resides in small town or cities, which are well represented in cartoons. Most of the Indian mythology stories are based in Kingdoms with king, queen etc., these too are well represented in cartoons, like in Chhota Bhim, Roll Number 21, etc.

The age of the protagonists is an important attribute to be considered. The age of the primary character is well co-relatable with the intended audience. Most cartoons protagonist's matches with the target audience's age group.

A few of the cartoon protagonists are aged 30+, namely, Motu Patlu, Kumbh Karan, Chorr Police but the age of the character they portray in these cartoon films justifies the age, and the stories that they are a part of.

Humans having supernatural powers are what all children dream and long to have. This desire is well represented in the cartoon films too. The benefits or advantages of the same, to fight evil forces, are depicted to be used or the wellbeing of the population.

The Indian cartoon films considered here is a start in many more cartoons to be made in India. Hope to see some more of them, along with the children. Chhota Bhim is the most popular cartoon while Super V, the most recent to be launched on TV.

The special characters/different characters are the ones which have superhuman capabilities, make things happen when the protagonist is stuck or in a fix or assist him, leads the audience, a desire to have a similar special character with them, which they look for or co-relate to within amongst their peers, in a hunt, which usually leads to no vain.

Over the years of the cartoon films being created and telecast, it is observed that the cartoon characters do not seem to age. The characters in the cartoons, over the years that they are telecast on TV, are still depicted as being of the same age, from when they were conceptualised and were seen on TV, still continue to exhibit characteristics and behaviors which are similar over the production time line in years.

The results can also be co-related to the question as to why some cartoon films are so popular. It is observed that the age of the cartoon character is a primary factor in deciding the popularity of the cartoon film. If the age group of the cartoon character, the protagonist matches with the age group of the target audience there is s higher chance of the cartoon films bring popular. The storyline being based on a locale which the audience can connect with makes the cartoon film being closely associated by the audience. 


\section{Conclusion}

This paper analysed the domestic (a.k.a. Desi) made in India creation of cartoon films. There are not many production houses which prepare cartoon films for children in India as of the time this paper goes to press. The popularity of these cartoon films is implied to be based primarily on the social connect it has with the language, lingo and the storylines of the same.

There is gender bias evident in favor of males in almost all cartoon films considered. Many storylines in episodes of cartoon films are based on the culture, rituals and festivals that are observed in India.

There is a strong influence of the mythological characters in the making of these films. The characters are also based on the characters of Indian mythology with characteristics and powers similar to those mentioned in the ancient scriptures.

It is time that the particular segment in mass media understood the importance of cartoon films in the Indian content and generated content which is less in stereotyping and adheres more to the changing social situation.

It is observed that these production houses are no more influenced by the existing cartoons from out of India which are dubbed and telecast in cartoon channels. They have started to focus on context, storylines and locales which are easily correlated by the Indian audience.

\section{References}

Adetula, E. (2017). Your favorite cartoons don't have five fingers because 'dropping a finger makes a huge difference. Retrieved from: https://metro.co.uk/2017/04/04/yourfavourite-cartoons-dont-have-five-fingers-because-dropping-a-finger-makes-a-hugedifference-6552810/. [Accessed 15 June 2019.]

Aliyeva, A. (2013). Hidden effects of cartoons on little spectators. Retrieved from: https:// www.azernews.az/analysis/58562.html. [Accessed 15 June 2019.]

Boshoff, P. (2013). Sexy girls, heroes and funny losers gender representations in children's TV around the world. M. Gotz, D. Lemish (eds.), Agenda, 27(3), 133-136.

Curtis, G. (2006). The cave painters: probing the mysteries of the world's first artists. New York, USA: Anchor Books.

Deloache, J., Bloom Pickard, M., Lobue, V. (2011). How very young children think about animals. In P. McCardle, S. McCune, J. A. Griffin, V. Maholmes (eds.), How animals affect us: examining the influences of human-animal interaction on child development and human health, 85-99. USA: American Psychological Association.

Desai, D. (2019). Why is Chutki from Chhota Bheem so meek? Retrieved from: https://ti mesofindia.indiatimes.com/life-style/spotlight/why-is-chutki-from-chhota-bheem-someek/articleshow/68408761.cms. [Accessed 15 June 2019.]

Gonick, L. (1997). The cartoon history of the universe: from the big bang to alexander the great. New York, USA: Three Rivers Press.

Karpyn, A., Allen, M., Marks, S., Filion, N., Humphrey, D., Ye, A. et al. (2016). Pairing animal cartoon characters with produce stimulates selection among child zoo visitors. Health Education \& Behavior, 44(4), 2016, 581-589. 
Lemish, D. (2007). Children and television: a global perspective. New Jersey, USA: Wiley-Blackwell.

Lemish, D., Johnson, C. R. (2019). The landscape of children's television in the US \& Canada. International Central Institute for Youth and Educational Television. The Center for Scholars \& Storytellers.

Postman, N. (1985). Amusing ourselves to death. USA: Penguin.

Sarzynski, T (2018). Cute animals in cartoons, why? Retrieved from: https://medium.com/ environmental-intelligence/cute-animals-in-cartoons-why-5f1201c08d43. [Accessed 15 June 2019.]

Serpell, J. (1999). Guest editor's introduction: animals in chilren's lives. Society \& Animals, $7(2), 87-94$.

Sultana, S. (2014). Role of cartoon: a brief discussion on how cartoon put an impact on children, ENH Community Journal, 1(1), 73-80.

Tardif, T., Fletcher, P., Liang, W., Zhang, Z., Kaciroti, N., Marchman, V. A. (2008). Baby's first 10 words. Developmental Psychology, 44(4), 929-938, DOI: 10.1037/00 12-1649.44.4.929.

Williams, R. (1990). Television: technology and cultural form. UK: Routledge. 



\title{
News Podcast Usage in Promoting Political Participation in Korea ${ }^{1}$
}

\author{
By Changho Lee*
}

\begin{abstract}
Based on an online survey of 734 news podcast users in Korea, this study analyzed how motivations for podcast use and news podcast variables affected offline and online political participation. The results showed that any motivation did not have a significant effect on offline and online participation. Rather, discussions about issues transmitted through news podcasts were a positive predictor of online participation as well as offline participation. The discussion was also a mediator in the relationship between the time spent on a news podcast and offlinelonline political participation. That is, news podcast use enhanced political discussions, which promoted participation offline and online. Overall, these results indicate that discussions are important in the mobilization of political participation in the era of podcast.
\end{abstract}

Keywords: podcast, news podcast, political discussion, online participation, offline participation

\section{Introduction}

Podcasts are audio files that can be downloaded or streamed from a smartphone at no cost (Perks and Turner, 2019). Podcasting came of age in 2005 and its emergence was solidified in 2015 when Apple upgraded to iTunes 4.9 (Bottomley, 2015). It is becoming popular with the development of audio technology and the spread of smartphone. Easy access to downloads and developments in technology have facilitated prominent a position of podcasts in the digital cultural industries (Vrikki and Malik, 2019). They enable an audience to time-shift: People can download them and tune in whenever they want (McClung and\& Johnson, 2010).

In the United States, $32 \%$ of Americans aged 12 and older have listened to podcast in the past month in 2019 while it was only 9\% in 2008 (Pew Research Center, 2019). According to Podtrac, which released top 20 podcasts rankings every month, as of August 2019, <The Daily> run by The New York Times ranked first, followed by <Stuff You Should Know> (iHeartRadio), <This American Life > (This American Life/Serial), <The Ben Shapiro Show $>$ (Daily Wire), and <Up First> (NPR) (Podtrac, 2019). Korean people are also heavy listeners of podcasts. According to Podbbang (www.podbbang.com), a platform of podcast in Korea, as of August 2019, there are about 23,000 podcasts including news, music, travel, sports, books, etc. Among them, news podcasts dealing with political

\footnotetext{
*Research Fellow, National Youth Policy Institute, Korea.

${ }^{1}$ This research is based on Podcast Journalism Study sponsored by Korea Press Foundation in 2018.
} 
matters and public issues are very popular. Out of 22 countries, the number of people who listened to podcast for the past month was highest in Korea (58\%), followed by Hong Kong (55\%), Taiwan (47\%), and Spain (40\%) (Korea Press Foundation and Reuters Journalism Institute, 2018).

To begin with, most of the Korean political podcasts only had an audio format and were critical of the existing political power. Especially, <Naneun Ggomsuda> meaning "I am a pretty-mined creep", a news podcast established in 2011, played an important role in criticizing the conservative government and revealing wrongdoings of political leaders. Using humor, satire, and parody, the podcast delivered news with interest and entertainment (Park, 2017). At that time when the podcast started, the mainstream media were controlled by the government. Thus, most of them were silenced on the criticism of government policy whereas <Naneun Ggomsuda> played a watchdog role. Therefore, this podcast was liked by many people with progressive political interests. Around December 2012, it was terminated, but four members of hosts created other news podcasts and continued their work. Later, conservative groups set up a number of video podcasts through YouTube channel to promote their political agenda and ideology. More specifically, these podcasts were targeted to older conservatives over 60s (Chung, 2019). Many of conservative podcasts were established in 2017 when the former president Geun-hye Park was impeached and Jae-in Moon, a liberal figure was elected as a new president of Korea. They argued that president Park was not guilty although she was convicted by Supreme Court and sentenced to jail. Accordingly, they were very active in transmitting conservative ideology and thoughts. Because of this spread of conservative news podcasts, the ideological conflicts between progressive and conservative groups to promote each political position are becoming fierce in Korea.

Although a lot of podcasts have been created over the past few years, many studies were focused on aforementioned <Naneun Ggomsuda> because it played an important role in watching and criticizing government (Lee and Hwang, 2013; Lee and Keum, 2012; Lee and Ryu, 2013). As a result, there are few studies addressing the relationship between news podcast and political participation in the situation of rapid diffusion of podcast.

Therefore, this study analyzes how a news podcast promotes offline and online political participation in the context of motivations for the medium and its use. Especially, drawing on the communication mediation model, the study investigates the mediating role of political discussions in the relationship between news podcast use and political participation.

\section{Theoretical Background}

\section{Motivations for Using Podcasts and Political Participation}

Uses and gratifications approaches in communication focus on why and for what purpose people use media. Different motivations lead to different communication choices and behaviors (Rubin and Step, 2000). For example, 
Rubin and Step (2000) identified four motives for talk radio listening: pass time/habit, exciting entertainment, escapist relaxation, and information. They found that entertainment motive was associated with talk radio exposure while information and pass time motivation were predictors of behavioral effect, a sense that the host influenced the listener to talk to others about politics or vote for political candidates. The study of college students showed that interpersonal utility motive of Internet use was a predictor of Internet affinity and information seeking motive was associated with Internet satisfaction (Zizi and Rubin, 2000). That is, those who want to fulfill interpersonal needs through the Internet are more likely to be attracted by the Internet. In addition, the more students use the Internet to find information, the more they are satisfied with the medium.

Reasons for listening to podcasts are varied. Perks and Turner (2019) found that parasocial relationships formation with podcast hosts, multitasking, entertainment, and education or learning something new were main motives. Podcasts were also most commonly replacements for radio/music and television. Entertainment, time shifting, library building, advertising, and social aspects were primary motives of podcast listening (McClung and Johnson, 2010). Interestingly, podcast users supported companies that advertise on podcasts (advertising motive) and they talked with friends about podcasts they downloaded (social aspects motive). According to a web-based survey of 137 podcasters, their reasons to start podcasting include public creativity, performance/promotion, long tail (e.g., convenience and freedom of the medium), and entertainment (Markman and Sawyer, 2014). Independent podcasters saw podcasting as an alternative to traditional media and they regularly attended podcasting events.

In Korea where political podcasts are popular, motivations included not only entertainment but also information seeking such as alternative press function (Lee, 2017) and political interests (Hwang and Kim, 2012). That is, people listened to podcasts to find information which mainstream media did not cover. They also depended much on podcasts for political information and diverse viewpoints of public issues. Because podcasts provide deep explanation and analysis of specific issues important to society, people can learn about what is occurring within society easily. Accordingly, political motivations are much stronger among Korean users because news podcasts are very popular in this country.

Several studies showed that there was a positive relationship between motivations and political participation. For example, the amusement motivation (relaxation/killing time) for using podcast as well as informational one (pursuit of alternative information) was positively related to offline participation of Korean college students (Lee and Keum, 2012). The motive for amusement was also positively associated with online participation. This result indicates that entertainment motivation is important in promoting political participation. However, another study showed that the motivations for exchanging information with others obtained from podcast was a strong predictor of not only offline participation but also online participation (Lee and Hwang, 2013).

As shown above, there are few studies on the relationship between motivations of podcast use and political participation. Furthermore, the study results are not consistent. Thus, this study suggests the following research 
question.

RQ 1: What motivations are associated with political participation?

\section{Podcast and Political Participation}

Recently, many scholars have focused on the relationship between social media news consumption and online/offline political, civic engagement (Gil de Zúñiga et al., 2012; Hao et al., 2014; Yang and DeHart, 2016). Overall, general use of social media was not associated with participation whereas political use of Social Network Service (SNS) was a critical predictor of participation. According to a study of university students in China and Hong Kong, information seeking via SNS was positively related to online and offline discussion, which led to online political participation ( $\mathrm{Li}$ and Chan, 2017). Offline discussion mediated between information seeking and offline political participation. Another study of U.S. college students also found that political use of Twitter or Facebook was an important predictor of online political participation (Yang and DeHart, 2016). On the other hand, Twitter use and Facebook use were negatively related to it. This result indicates that news consumption for acquisition of current affairs is related to political participation, and therefore not the time spent on the media.

In addition to SNS, political podcasts are becoming a new source of information for political issues and contributed to enhancing and facilitating political participation, especially among young generation (Lee and Ryu, 2013; Song, 2012). Although there are limited number of studies on podcast, several studies have shown that there is a positive relationship between news podcast use and political participation. For example, Chadha and colleagues found that podcast was a strong predictor of online and offline political participation although their study focused on podcast in general, not on specific type of podcast such as politics and economy (Chadha et al., 2012). Lee and Ryu (2013) found that political podcast < Naneun Ggomsuda > use was positively related to political participation as well as political interest and efficacy of high school students and college students. The analysis showed that the podcast enhanced the political interests of high school students while it promoted political participation of college students.

Political discussion is also an important factor which can lead to political participation. It provides opportunities to learn information and ponder about public issues and reach common understanding (Valenzuela et al., 2011). It also promotes political efficacy. Political discussion with weak ties (acquaintances or strangers) was a mediator between news use and internal political efficacy (Ardèvol-Abreu et al., 2017). That is, the new information from the media fosters political discussion about issues, which lead to an increased self-perception of competence in participating in the democratic process. Political discussion with weak-ties and like-minded people were positively associated with online political participation (Valenzuela et al., 2011).

News podcast users are relatively young and progressive and are much 
interested in political issues (Min, 2014). Therefore, it is expected that news podcast use will lead to their active participation in society. Based on the previous literature, this study suggested the following hypotheses.

H1: The use time of news podcast is positively related to offline political participation.

H2: The use time of news podcast is positively related to online political participation.

H3: Political discussion on issues transmitted through news podcast is positively related to offline political participation.

H4: Political discussion on issues transmitted through news podcast is positively related to online political participation.

\section{Communication Mediation Model}

Communication mediation model highlights the importance of political discussion in promoting political participation. This model articulates that campaign advertisements exposure stimulate information seeking via mass media, which in turn leads to interpersonal exchanges about politics (Cho et al., 2009). This reasoning process through discussion causes participatory activities. By integrating mass and interpersonal information channels, the model shows a process whereby news consumption yields various attitudinal and behavioral outcomes (Lee, 2012). Shah and colleagues found that informational media use encouraged citizen communication, which affected civic participation (Shah et al., 2007). Accordingly, this model places discussion among citizens in a mediating position between news consumption and civic engagement (Shah et al., 2017).

This model has been supported by many studies. For example, Lee (2012) analyzed the mediating role of interpersonal talk between late-night comedy viewing and political participation. As a result, discussion with neighbors, friends and family and the number of people with whom respondents talk about politics fully mediated the relationship. The study of Korean political news podcasts showed that they promoted political discussion via online/mobile media which in turn affected political participation in the presidential election in 2012 (Min, 2015). On the contrary, the mediating role of political discussion offline was not confirmed in this study. Recently, Zúñiga and colleagues (Gil de Zúñiga et al., 2019) examined the applicability of the citizen communication model across 19 countries. They found that news use and political discussion were related to political participation across countries. In addition, political discussion mediated the relationship between news and participation. In more democratic societies, discussion was positively associated with political participation. According to the study on university students in Taiwan, Hong Kong, and China, political discussion was a predictor of political efficacy, which in turn led to offline and online political participation (Chan et al., 2017). In the Hong Kong and China sample, political discussion mediated the relationship between political messaging on mobile and social media and 
online participation. However, there was no direct relationship between mobile news and social media news and political discussion.

Drawing on the communication mediation model, the following hypotheses were suggested.

H5: Political discussion will mediate between news podcast and offline political participation.

H6: Political discussion will mediate between news podcast and online political participation.

\section{Method}

\section{Sample}

This research is based on an online survey of 1,000 podcast users in Korea, which was conducted for a week in mid-July in 2018. The research company which has the most online panels conducted this survey. First, panels were asked to select channels including podcast, Africa TV, Naver audio clip, and other new media services in Korea, they used for the past one month. As a result, 6,859 people clicked the survey link and among them 2,771 respondents selected podcast. Out of 2,771 podcast users, 1,000 respondents could participate in the survey because the target sample size was 1,000 people. Quota sampling in consideration of gender and age was used to enhance the representativeness of the population. As a result, gender and age distribution of sample (male $51.2 \%$, female $48.8 \%$; 20s $21.9 \%$, 30s $23.1 \%$, 40s $27.7 \%$, 50s $27.3 \%$ ) were almost the same as that of population in Korea (male $51.2 \%$, female $48.8 \%$; 20s $21.9 \%$, 30s $23.4 \%$, 40s $27.4 \%$, 50s $27.2 \%$ ).

Because this research was focused on news podcast, we used 734 respondents for the analysis, who said that they used news podcast at least once for the past one month. Of the sample, $401(54.6 \%)$ were males and $303(45.4 \%)$ were females: $135(18.4 \%)$ were in $20 \mathrm{~s}, 152(20.7 \%)$ were in $30 \mathrm{~s}, 224(30.5 \%)$ were in $40 \mathrm{~s}$, and $223(30.4 \%)$ were in 50 s.

\section{Measures}

Dependent variables. Offline participation (5 items) was measured by whether respondents participated in the following activities for the past one year at the time of survey; demonstrations, signature campaign, boycott, voting and making a complaint call to government and public institutions. Items were rated on Yes (1) or No (0) and averaged for the analysis $(M=2.20, S D=1.11)$. SNS participation ( 5 items) was measured by the extent to which respondents read political messages, posted their opinions about political issues, replied to others' messages, shared messages of other people and participated in online petition via SNS. Items were adapted from Bai (2015). Each item was rated from 1 (never) to 4(often) and averaged $(\alpha=.82, \mathrm{M}=2.30, S D=.65)$. 
Independent variables. Motivations for podcast use was composed of four factors, considering previous studies (Lee, 2017; Lee and Hwang, 2013; Hwang and Kim, 2012). Entertainment motivation indicates that people use podcast for amusement or pleasure while access motivation means that people get access to podcast easily. Information seeking motivation indicates that people use podcast to get information about social, political issues. Finally, alternative media motivation means that people depend on podcast to find information which cannot be found in mainstream media. Each factor comprised three items and was rated on a 5-point Likert scale ( $1=$ strongly disagree $\sim 5=$ strongly agree). To check whether items are consistent with each factor, we conducted confirmatory factor analysis. However, one item "I use podcast just to kill time" had a very low factor loading value $(0.162)$ in entertainment factor and was excluded from the analysis. As shown in Table 1, all the value of factor loadings indicated over 0.5 , which was acceptable. AVE (Average Variance Extracted) value was over 0.5 and CR (Composite Reliability) value was over 0.7 except for entertainment motivations. Although RMSEA value was a little more than criterion value (0.08), the value of CFI and TLI indicated over 0.9 , which was an acceptable level. Reliability coefficient was over 0.6 and it was acceptable.

Table 1. Confirmatory Factor Analysis of Motivations for Podcast Use

\begin{tabular}{|c|c|c|c|c|c|c|}
\hline Factor & $\begin{array}{r}\text { Item } \\
\text { (I use podcast }\end{array}$ & $\begin{array}{l}\text { Factor } \\
\text { loading }\end{array}$ & SE & AVE & CR & $\alpha$ \\
\hline \multirow{2}{*}{ Entertainment } & For amusement & 0.745 & 0.025 & \multirow{2}{*}{0.496} & \multirow{2}{*}{0.663} & \multirow{2}{*}{0.654} \\
\hline & To comfort me & 0.662 & 0.029 & & & \\
\hline \multirow{3}{*}{ Access } & To listen to it at any time & 0.788 & 0.021 & \multirow{3}{*}{0.546} & \multirow{3}{*}{0.708} & \multirow{3}{*}{0.767} \\
\hline & To listen to it repeatedly & 0.599 & 0.027 & & & \\
\hline & To listen to it anywhere & 0.814 & 0.023 & & & \\
\hline \multirow{3}{*}{$\begin{array}{l}\text { Information } \\
\text { seeking }\end{array}$} & $\begin{array}{l}\text { To get information in detail } \\
\text { about social, political issues }\end{array}$ & 0.945 & 0.027 & \multirow{3}{*}{0.789} & \multirow{3}{*}{0.898} & \multirow{3}{*}{0.909} \\
\hline & $\begin{array}{c}\text { To get detailed explanations } \\
\text { and interpretations }\end{array}$ & 0.955 & 0.027 & & & \\
\hline & To know about recent issues & 0.750 & 0.027 & & & \\
\hline \multirow{3}{*}{$\begin{array}{l}\text { Alternative } \\
\text { media }\end{array}$} & $\begin{array}{c}\text { To know about issues which } \\
\text { cannot be found in } \\
\text { mainstream media }\end{array}$ & 0.874 & 0.029 & \multirow{3}{*}{0.586} & \multirow{3}{*}{0.713} & \multirow{3}{*}{0.826} \\
\hline & $\begin{array}{c}\text { To like unhindered criticism } \\
\text { about existing political } \\
\text { power }\end{array}$ & 0.721 & 0.032 & & & \\
\hline & To like straightforward talk & 0.690 & 0.031 & & & \\
\hline
\end{tabular}

Note: Chi-square $=438, d f=38, p<0.001, \mathrm{CFI}=0.938, \mathrm{TLI}=0.910$, RMSEA=0.103

In addition to motivations, we measured news podcast in terms of use time and discussion. First, we asked respondents how much time they spent on listening to news podcast per day on average. This item is rated on a 5-point Likert Scale (1=less than 30 minutes $\sim 5=$ more than 2 hours). Discussion indicates how often they talk about political issues with people, which was transmitted through 
political podcasts. This single item was rated according to the Likert scale from 1(never) to 4(very often).

\section{Control Variables}

News media use was measured by the amount of time respondents spent on printed newspapers, TV, Internet newspapers including portals and online version of traditional newspapers, and SNS per day. Each item was rated according to the Likert scale from 1 (never) to 6 (more than 2 hours). The mean and standard deviation of each variable is following: printed newspapers $(M=1.73, S D=1.05)$, TV $(\mathrm{M}=3.19, S D=1.11)$, Internet newspapers $(\mathrm{M}=3.29, S D=1.11)$, and SNS $(\mathrm{M}=2.67, S D=1.23)$.

Political variables are also controlled. Political ideology adapted from Min (2014) was measured by respondents' subjective political orientation. It ranged from conservative (1) to progressive (7). Degree of interest in politics drawn from Kim and Yang (2013) was measured by the extent to which respondents were interested in political issues, governmental policy, political party, politicians, and TV political debate. Each item was measured on a 4-point Likert scale ( $1=$ never to $4=$ very much) and averaged $(\alpha=0.86, \mathrm{M}=2.79, S D=0.58)$. Political efficacy was measured by the extent of participants' agreement on three items such as "I have the capacity to understand political issues and participate in politics" and "My political interest and participation will be helpful for desirable management of state affairs." All items were rated on a 5-point scale (1=strongly disagree to $5=$ strongly agree) and averaged $(\alpha=0.83, \mathrm{M}=3.62, S D=0.67)$. Items were drawn from Kim (2009) and Jung et al. (2011).

In addition to these variables, gender, age and income were used as control variables. The monthly average income of a family (Korean money unit) was rated on a 6-point Likert scale (1=less than $1,000,000$ won $\sim 6=$ more than $5,000,000$ won); $\mathrm{M}=4.47, \mathrm{SD}=1.43)$.

\section{Analysis}

To analyze the effect of motivations for podcast and news podcast on offline and online political participation, we used hierarchical multiple regression analysis with SPSS 22.0. Demographic variables were entered first, followed by political variables, news media use, motivations for podcast use, news podcast, and online or offline participation. Next, we used PROCESS to analyze the mediation effect of political discussion in the relationship between news podcast use and political participation, controlling for political interest and efficacy.

\section{Results}

Table 2 shows how input variables affect offline political participation. Among them, online participation had the greatest influence on it $(\beta=0.346$, 
$\mathrm{p}<0.001)$. People who participate in activities online are more likely to attend political rallies or participate in a signature campaign. The extent of discussions on issues which was broadcast on podcast was also associated with offline participation $(\beta=0.113, \mathrm{p}<0.001)$, supporting hypothesis 3 . However, news podcast use was not related to political participation. Therefore, hypothesis 1 that news podcast use will affect offline participation was not supported. In addition, any motivation for podcast use had no significant relationships with participation. Among control variables, only gender and political ideology had a slightly significant effect. The model explained $21.9 \%$ of variance in offline political participation $\left(\mathrm{F}=81.087, p<0.001\right.$; Adjusted $\left.\mathrm{R}^{2}=0.219\right)$.

Table 2. Hierarchical Regression Analysis Predicting Offline Political Participation

\begin{tabular}{|c|c|}
\hline Variables & Standardized regression coefficient \\
\hline \multicolumn{2}{|l|}{ Block 1. Demographics } \\
\hline Gender $($ female $=1)$ & $0.081^{*}$ \\
\hline Age & -0.044 \\
\hline Income & 0.023 \\
\hline$\Delta \mathrm{R}^{2}$ & 0.013 \\
\hline \multicolumn{2}{|l|}{ Block 2. Political variables } \\
\hline Political ideology & $0.065^{+}$ \\
\hline Political interest & 0.044 \\
\hline Political efficacy & 0.055 \\
\hline$\Delta \mathrm{R}^{2}$ & 0.081 \\
\hline \multicolumn{2}{|l|}{ Block 3. News media use } \\
\hline Newspaper & 0.035 \\
\hline TV & -0.020 \\
\hline Internet & -0.038 \\
\hline SNS & 0.064 \\
\hline$\Delta \mathrm{R}^{2}$ & 0.027 \\
\hline \multicolumn{2}{|c|}{ Block 4. Motivations for podcast use } \\
\hline Entertainment & 0.012 \\
\hline Access & 0.032 \\
\hline Information seeking & 0.025 \\
\hline Alternative media & -0.003 \\
\hline$\Delta \mathrm{R}^{2}$ & 0.007 \\
\hline \multicolumn{2}{|l|}{ Block 5. News podcast } \\
\hline Use time & -0.018 \\
\hline Discussion & $0.113^{* *}$ \\
\hline$\Delta \mathrm{R}^{2}$ & 0.023 \\
\hline Block 6. Online participation & $0.346^{* * *}$ \\
\hline$\Delta \mathrm{R}^{2}$ & 0.086 \\
\hline $\mathrm{R}^{2}$ & 0.237 \\
\hline Adjusted $\mathrm{R}^{2}$ & 0.219 \\
\hline
\end{tabular}

Table 3 indicates the predictors of online political participation. Offline 
participation and political interest were strongly associated with online participation (each $\beta=0.294, p<0.001$ and $\beta=0.207, p<0.001$ ). Among news media use, newspaper, Internet and SNS were positively related to online activities such as online petition or sharing messages. Political discussion was also a critical predictor as it was in offline participation, supporting hypothesis 4. However, any motivations for podcast use were not related to online participation. Unexpectedly, the use time of news podcast was negatively associated with online participation. Therefore, hypothesis 2 that podcast use is positively related to online participation was not supported. The model explained $33.8 \%$ of variance in offline political participation ( $\mathrm{F}=81.087, p<0.001$; Adjusted $\left.\mathrm{R}^{2}=0.338\right)$.

Table 3. Hierarchical Regression Analysis Predicting Online Political Participation

\begin{tabular}{|c|c|}
\hline Variables & Standardized regression coefficient \\
\hline \multicolumn{2}{|l|}{ Block 1. Demographics } \\
\hline Gender $($ female $=1)$ & -0.016 \\
\hline Age & 0.018 \\
\hline Income & -0.025 \\
\hline$\Delta \mathrm{R}^{2}$ & 0.003 \\
\hline \multicolumn{2}{|l|}{ Block 2. Political variables } \\
\hline Political ideology & -0.020 \\
\hline Political interest & $0.207^{* * * *}$ \\
\hline Political efficacy & $0.071^{*}$ \\
\hline$\Delta \mathrm{R}^{2}$ & 0.147 \\
\hline \multicolumn{2}{|l|}{ Block 3. News media use } \\
\hline Newspaper & $0.091^{* *}$ \\
\hline TV & -0.023 \\
\hline Internet & $0.108^{* *}$ \\
\hline SNS & $0.186^{* * *}$ \\
\hline$\Delta \mathrm{R}^{2}$ & 0.102 \\
\hline \multicolumn{2}{|c|}{ Block 4. Motivations for podcast use } \\
\hline Entertainment & -0.058 \\
\hline Access & 0.019 \\
\hline Information seeking & 0.060 \\
\hline Alternative media & 0.002 \\
\hline$\Delta \mathrm{R}^{2}$ & 0.007 \\
\hline \multicolumn{2}{|l|}{ Block 5. News podcast } \\
\hline Use time & $-0.069^{*}$ \\
\hline Discussion & $0.101^{* *}$ \\
\hline$\Delta \mathrm{R}^{2}$ & 0.021 \\
\hline Block 6. Offline participation & $0.294^{* * * *}$ \\
\hline$\Delta \mathrm{R}^{2}$ & 0.073 \\
\hline $\mathrm{R}^{2}$ & 0.353 \\
\hline Adjusted $\mathrm{R}^{2}$ & 0.338 \\
\hline
\end{tabular}

Drawing on the communication mediation model, we analyzed the path from 
news podcast use to participation mediated by political discussion, controlling for political interest and efficacy. We applied PROCESS model 4 (5,000 bootstrap samples, 95\% CIs). The result showed that news podcast use did not have a significant direct effect on offline participation, but had an indirect effect (see Figure 1). That is, news podcast promoted political discussion $(\beta=0.217, p<.001$, $\mathrm{CIs}=[0.093,0.182])$, which in turn had a positive influence on political participation $(\beta=0.180, p<.001, \mathrm{CIs}=[0.173,0.416])$. This indirect effect was statistically significant $(\mathrm{CIs}=[0.021,0.064])$. This result indicates that political discussion mediated between news podcast and offline political discussion. Thus, hypothesis 5 that political discussion will be a mediating variable between news podcast use and offline political participation was supported.

Figure 1. The Effect of News Podcast Use on Offline Participation in Mediation of Political Discussion

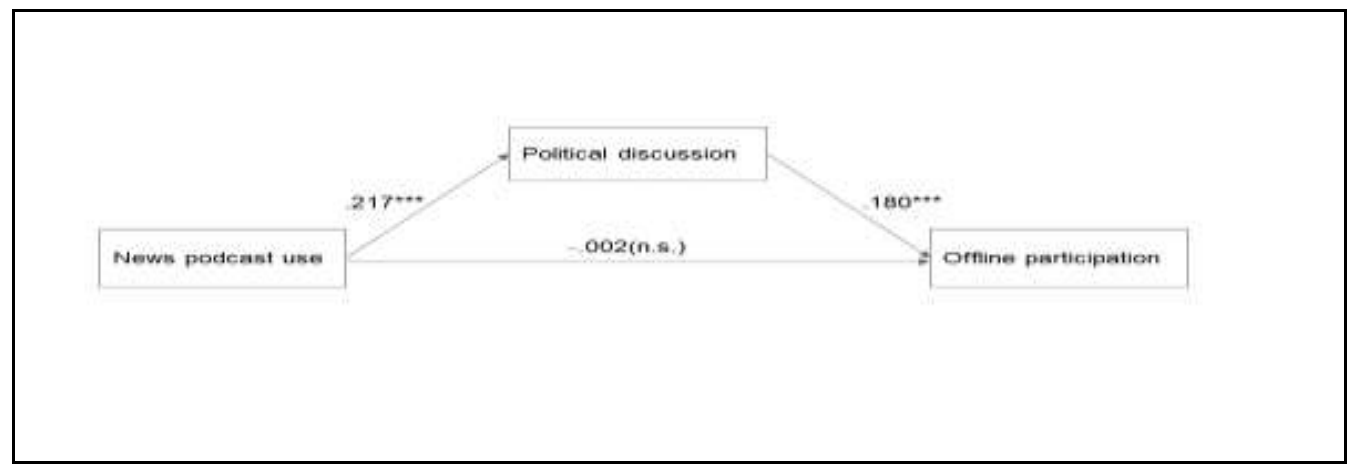

Figure 2 indicates the effect of news podcast use on online participation in mediation of political discussion. The direct effect of news podcast use on online participation was not significant $(\mathrm{CIs}=[-0.051,0.031])$. On the contrary, political discussion was found to be a mediated variable between news podcast and online participation, which supported hypothesis 6. That is, news podcast affected political discussion positively, which in turn was related to online participation $(\beta=0.168, p<.001, \mathrm{CIs}=[0.089,0.221])$. Thus, the indirect effect of news podcast on online participation was confirmed $(\mathrm{CIs}=[0.018,0.058])$.

Figure 2. The Effect of News Podcast Use on Online Participation in Mediation of Political Discussion

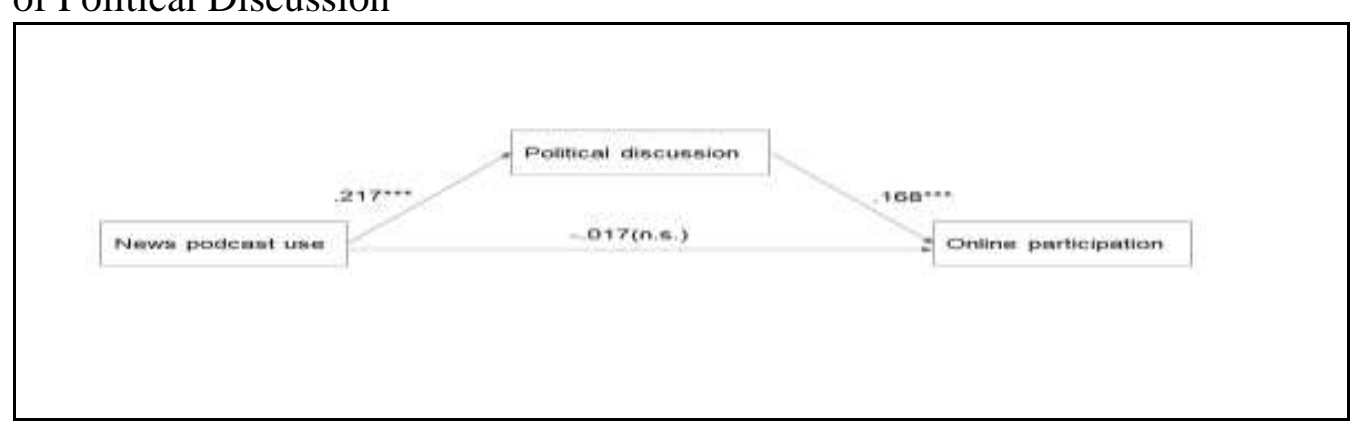

Conclusion 
Now news podcasts are popular in Korea. This popularity is partly attributed to low credibility of mainstream media. Thus, many Korean people depend on SNS or podcasts for information. In this study, alternative media motive was one of four motives of podcast use. This indicates that users of news podcast use it to obtain information which mainstream media cannot transmit.

This study analyzed the predictors of offline and online political participation, focusing on motives and use of podcasts. Overall, the results showed that motivations were not associated with political participation. Furthermore, the time spent on news podcast was not a predictor of offline participation. Rather, it was negatively associated with online participation. On the other hand, discussion with people about current events or public issues was a critical predictor of political participation offline as well as online. This result indicates that talking about issues and sharing them with others are important in the promotion of political behaviors. Podcasts are an open platform for communication where people can explore and discuss issues that interest or concern them (Vrikki and Malik, 2019). This interactive medium activates political discussions, which might lead to political participation.

Offline participation and online participation were intimately related to each other. With the development of technology, participation on line has been active.

Drawing on the communication mediation model, this study tested the mediating role of political discussion between news podcast use and participation. Thus, it was confirmed that the use of news podcast was positively associated with discussion, which led to offline and online participation. That is, the time spent on news podcast was not directly related to participation. Rather, it was indirectly associated with offline and online participation by way of political discussion. This result supports communication mediation model and previous studies related to it. It also implies that the model can applied in the medium of podcast. Until now, there have been few studies which applied the communication mediation model to news podcasts. In this respect, this study is meaningful. It showed that political discussion could play a mediating role between news podcast use and offline/ online participation. Therefore, discussion needs to be revitalized to promote political activities.

Despite this contribution, this study has several limitations. First of all, it did not compare news podcast users and non-users. Future studies need to compare how much different users and non-users are in their political behaviors and attitudes.

\section{References}

Ardèvol-Abreu, A., Diehl, T., Gil de Zúñiga, H. (2017). Antecedents of internal political efficacy incidental news exposure online and the mediating role of political discussion. Politics, 39(1), 1-19.

Bai, S. Y. (2015). A study on the utilization of social media for the revitalization of youth culture. Sejong, Korea: National Youth Policy Institute.

Bottomley, A. J. (2015). Podcasting: a decade in the life of a "new" audio medium: introduction. Journal of Radio \& Audio Media, 22(2), 164-169. 
Chadha, M., Avila, A., Gil de Zúñiga, H. (2012). Listening in: building a profile of podcast users and analyzing their political participation. Journal of Information Technology \& Politics, 9(4), 388-401.

Chan, M., Chen, H-T, Lee, F, L. F. (2017). Examining the roles of mobile and social media. In political participation: a cross-national analysis of three Asian societies using a communication mediation approach. New Media \& Society, 19(12), 20032021.

Cho, J., Shah, D. V., McLeod, J. M., McLeod, D. M., Scholl, R. M., Gotlieb, M. R. (2009). Campaigns, reflection, and deliberation: advancing an O-S-R-O-R model of communication effects. Communication Theory, 19(1), 66-88.

Chung, C. (2019). Korea's far-right disinformation industry targets older conservatives. Retrieved from: https://codastory.com/disinformation/disinfo-newsletter/korea-farrig ht-youtube/. [Accessed 13 September 2020.]

Gil de Zúñiga, H., Jung, N., Valenzuela, S. (2012). Social media use for news and individuals' social capital, civic engagement and political participation. Journal of Computer-Mediated Communication, 17(3), 319-336.

Gil de Zúñiga, H., Diehl, T., Huber, B., Liu, J. H. (2019). The citizen communication mediation model across countries: a multilevel mediation model of news use and discussion on political participation. Journal of Communication, 69(2), 144-167.

Hao, X., Wen, N., George, C. (2014). News consumption and political and civic engagement among young people. Journal of Youth Studies, 17(9), 1221-1238.

Hwang, H., Kim, J. (2012). A study on the podcast usage and political participation of voters in their twenties in Seoul: a case study of listening i'm a petty trickster. The Journal of Social Science, 19(3), 151-184.

Jung, N., Kim, Y., Gil de Zúñiga, H. (2011). The mediating role of knowledge and efficacy in the effects of communication on political participation. Mass Communication and Society, 14(4), 407-430.

Kim, M. (2009). The effects of participation in the youth assembly of Republic of Korea on democratic attitude. Politics \& information Studies, 12(2), 119-142.

Kim, E., Yang, S. E. (2013). The new citizenship of digital natives and the influence of network media. Korean Journal of Journalism \& Communication Studies, 57(1), 305-334.

Korea Press Foundation, Reuters Journalism Institute (2018). Digital news report Korea. Seoul, Korea: Korea Press Foundation \& Reuters Journalism Institute.

Lee, H. (2012). Communication mediation model of late-night comedy: the mediating role of structural features of interpersonal talk between comedy viewing and political participation. Mass Communication and Society, 15(5), 647-671.

Lee, J. (2017). The effects of podcast usage and perceptions of podcast advertising on the purchase intention for products in podcast advertising and the execution intention for podcast advertising. Korean Journal of Broadcasting and Telecommunication Studies, 31(4), 170-204.

Lee, D., Hwang, S. (2013). The usage motivation of political podcast <Naneun Ggomsuda> and its influence in on-and offline political participation: based on the survey of 2040 users in Seoul. Media, Gender \& Culture, 26, 141-175.

Lee, J., Kuem, H. (2012). A study on the impacts of using politics podcasts on on/off-line political participation: focused on motivations for using politics podcasts by the users in their 20s, political psychology variables and on/off-line political participation variables. Korean Journal of Journalism \& Communication Studies, 56(5), 163-189.

Lee, C., Ryu, S. J. (2013). The effect of <Nanun KKomsuda $>$ on the political socialization of high school and university students: focusing on political interest, political efficacy, 
political knowledge, and political participation. Journal of Communication Science, 13(3), 490-526.

Li, X., Chan, M. (2017). Comparing social media use, discussion, political trust and political engagement among university students in China and Hong Kong: an application of the O-S-R-O-R model. Asian Journal of Communication, 27(1), 6581.

Markman, K. M., Sawyer, C. E. (2014). Why pod? Further explorations of the motivations for independent podcasting. Journal of Radio \& Audio Media, 21(1), 20-35.

McClung, S., Johnson, K. (2010). Examining the motives of podcast users. Journal of Radio \& Audio Media, 17(1), 82-95. doi: 10.1080/19376521003719391

Min, Y. (2014). The intertwining of news and entertainment: the effects of political podcasts in the 2012 Korean presidential election. Korean Journal of Journalism \& Communication Studies, 58(5), 70-96.

Min, Y. (2015). Political satire and participatory citizenship: effects of political podcasts on political participation. Korean Journal of Broadcasting \& Telecommunication Studies, 29(3), 36-69.

Park, C. (2017). Citizen news podcasts and engaging journalism: the formation of a counter-Public sphere in Korea. Pacific Journalism Review, 23(1), 245-262.

Perks, L, G., Turner, J. S. (2019) Podcasts and Productivity: a qualitative uses and gratifications study. Mass Communication and Society, 22(1), 96-116.

Pew Research Center (2019). Audio and podcasting fact sheet. Retrieved from: https://ww w.journalism.org/fact-sheet/audio-and-podcasting/. [Accessed 13 September 2020.]

Podtrac (2019). Podcast industry ranking top 20 podcasts us audience: August 2019. Retrieved from: http://analytics.podtrac.com/industry-rankings. [Accessed 13 September 2020.]

Rubin, A. M., Step, M. M. (2000). Impact of motivation, attraction, and parasocial interaction on talk radio listening. Journal of Broadcasting \& Electronic Media, 44(4), 635-654.

Shah, D. V., Cho, J., Nah, S., Gotlieb, M. R., Hwang, H., Lee, N. et al. (2007). Campaign ads, online messaging, and participation: extending the communication mediation model. Journal of Communication, 57(4), 676-703.

Shah, D. V., McLeod, D. M., Rojas, H., Cho, J., Wagner, M. W., Friedland, L. A. (2017). Revisiting the communication mediation model for a new political communication Ecology. Human Communication Research, 43(4), 491-504.

Song, I. (2012). The effects of $<$ Naneun Ggomsuda $>$ on college students' political knowledge, political self-efficacy, and political participation. Political Communication Studies, O(27), 101-147.

Valenzuela, S., Kim, Y., Gil de Zúñiga, H. (2011). Social networks that matter: exploring the role of political discussion for online political participation. International Journal of Public Opinion Research, 24(2), 163-184.

Vrikki, P., Malik, S. (2019) Voicing lived-experience and anti-racism: podcasting as a space at the margins for subaltern counterpublics. Popular Communication, 17(4), 273-287.

Yang, H., Dehart, J. L. (2016). Social media use and online political participation among college students during the US election 2012. Social Media + Society, 2(1), 1-18.

Zizi, P., Rubin, A. M. (2000) Predictors of internet use. Journal of Broadcasting \& Electronic Media, 44(2), 175-196. 


\title{
Communication Vices that Engender Development: Oxymoronic Relevance of Social Media Use in Nigeria
}

\author{
By Chukwuma Anyanwu* \& Elo Ibagere ${ }^{ \pm}$
}

\begin{abstract}
The Nigerian journalist has lost his monopoly of information gathering, dissemination and control with the involvement of citizens in 'journalism' through social media especially Whatsapp. The objective of this paper is to show how through social media, with emphasis on Whatsapp, Nigerian citizens have been able to find their voices and can now contribute to societal well-being and development by embarking on information gathering and reporting. It uses participant-observation method to interrogate how citizen journalism has engendered development via negative journalism practice. The findings indicate that the government and other relevant stakeholders in the society respond to the voices of the people on issues which ordinarily would have been muted by conventional journalism practice or ignored by government. It concludes that citizen journalism through unconscious and unprofessional practice engenders development by somehow making government accountable through its response to issues of concern in areas that would otherwise, have been muted.
\end{abstract}

Keywords: social media, citizen journalism, development, communication vices, Whatspp, Nigeria

\section{Introduction}

Before now, the Nigerian journalist had it all. He was the voice, the authority and the only one that could speak and the government and or other demi-gods in the society would listen. His words had weight; his information choice, vis-a-vis what gets disseminated or not was final. This monopoly has suffered drastically with the evolution of social media and their bringing into existence the new voices, the voices of the citizens through citizen journalism. This latest addition to journalistic practice has become the bane of both government and those who have hitherto commanded and determined what the media should cover. Citizen journalism erodes all manners of traditional media power, forcing all to follow its lead or become mere observers. As Xi has observed,

The emerging forms of media, labelled as the new media, have pervaded in an unprecedented manner nearly all aspects of our everyday life, penetrated into the semi-autonomous social subsystems of politics, economy, and the military, and created constellations of interactions and exchanges unseen before, (2017, p. 273).

Social media are of course important parts of the new media. The evolution or, is it incursion? Of social media with their numerous platforms for information

\footnotetext{
*Senior Lecturer, Department of Theatre Arts Faculty of Arts, Delta State University, Nigeria. ${ }^{ \pm}$Senior Lecturer, Department of Theatre Arts Faculty of Arts, Delta State University, Nigeria.
} 
gathering and dissemination into Nigeria can best be described in oxymoronic terms as a necessary evil. They have provided new avenues for information dissemination and publicity for all categories of people and professions. The new media (internet based media) "have altered the meaning and significance of geograph" as well as reduced "inequality in mainstream media attention," (Verboord and van Noord, 2016, p. 60). This clearly shows that distance and class have been eroded as the new media have become open access sesame for everybody.

They can be said also to have come to wake from apparent slumber or lethargic somnambulism the average Nigerian who before now, used to venerate the journalistic profession. The social media have come to offer the rural semiliterate and even the complete illiterate Nigerian the freedom of expression which was not available to him/her with the traditional media. The social media have come to make journalists out of every Nigerian who can afford a handset that has the requisite applications to engage in information gathering, collation and dissemination. It does not matter whether the citizen journalist has any knowledge of journalism; it does not matter whether he can speak or write good English, what matters is that he has something to say, which in his thinking must be said. And he is the most qualified person to say it! This paper discusses the new wave of journalistic experience through social media which tends to rubbish the sacred nature and hallowed ethical journalistic and conventional practice of the profession. It does this through the examination of some social media platforms with emphasis on selected Whatsapp Chat Groups to which the writers belong and the information emanating from them. Needless to say, the writers are participant observers and are therefore, drawing from their experience.

\section{Conceptual Definition of Terms}

In the "Foreword" to Many Voices, One World, M'Bow, in his opening sentence says, "communication is at the heart of all social interactions," (1981, p. viii). For the Sean MacBride Commission, "communication maintains and animates life," (1981, p. 3); and for Adeseye and Ibagere, "communication is as old as man," (1999, p. 67). Communication entails the sharing or passing on of ideas, information, experience, from one party to the other so that it can be understood and acted upon. In a communication encounter, the underlining word is sharing. In other words, there must be something to be shared for communication to occur. Having been shared, the other party or parties in the sharing/ communication experience must react or respond for the experience to be complete. This reaction necessarily means that the shared experience was either understood or not. It does not mean that the response must be favourable rather it shows that communication has taken place. Talabi et al. (2018, p. 3), are of the view that "communication is key to the development of any society hence, man cannot not communicate." This makes communication a necessity for man. With communication, man interacts with fellow human beings and conducts his daily businesses, locally, nationally and internationally. For communication to be 
effective it must be couched in comprehensible language; it must be clear and concise and must address specific issues of interest and concern to the receiver. Without communication in whatever form, man cannot make meaning of life nor can he make progress of any sort. If communication is this important to man, what then can be regarded as communication vices?

Not all fake news or instances of misinformation are malicious. Stand-up comedians, writers and children generally create vivid scenes that if well-structured along the $5 \mathrm{~W}$ 's and $\mathrm{H}$ would qualify as faultless fake news. We need to pay closer attention to the variants of news so that we know what to tackle. When we cross writer's intention with content integrity, we have nine variants of news in our current information ecosystem. And when we examine the under currents of these nine variants, we will see where hate speech and fake news meet. There are three possible intentions of a today's news writer in the post-truth environment: to amuse the audience, to amass traffic and thereby money, or to attack, demean, or scare a person, group or organisation. The content of a piece of fake news may be factual, twisted or completely fabricated (Ojebode, 2018, p. 6).

In the above quotation, Ojebode does not only help us identify what constitutes "communication vices", but he also goes on to tell us the reasons why the writers of these communication vices do so. It is, therefore, clear that fake news, hate speech, deliberate misinformation/propaganda, as well as stand up comedies among others qualify as communication vices. Being vices does not mean that they are all malicious. Some are meant to amuse; some to create followership and gain a measure of popularity while some are not meant for noble intentions. Having identified communication vices as used in this paper, our attention would now shift to the phrase, "oxymoronic relevance". Oxymoron (noun) is a literary term, a figure of speech which uses opposite terms to illustrate a point. The Oxford Dictionary Thesaurus \& Wordpower Guide, $2^{\text {nd }}$ Edition, (2001, pp. 918-919), sees the term as, "noun", a figure of speech or expressed idea in which apparently contradictory terms appear in conjunction (e.g., bittersweet). Of course, "oxymoronic" is its adjectival form. On their part, social media are the latest technological additions to the communications family. By their nature, they are not strictly mass media nor can they be classified as interpersonal communication because they have trappings of both. Social media have been seen by experts as "internet based applications", technology driven, "online tools and utilities," that permit online communication of information, encourage interactive participation and are websites that allow and encourage "user generated content," (Omosotomhe and Olley, 2018; Uzuegbunam and Omenugha, 2018).

In their seven years research entitled, "Risk, Crisis, and Social Media: A systematic review of seven years' research," the duo of Rasmussen and Ihlen cite Hogan and Quan-Haase, when they submit:

We approach social media as web-based platforms whose key applications offer opportunities for users to communicate and maintain social relationships with multiple individuals. The most optimistic accounts of social media convey that platforms such as Facebook, Twitter and You Tube offer anyone with necessary 
knowledge and Internet access the opportunity to engage in many-to-many dialogue across the globe (Rasmussen and Ihlen, 2017, p. 2).

They went further on the same page to posit that, "empirical studies show strong patterns of homophily in social media, in that elites follow elites whereas "ordinary" citizens rarely get attention." This observation may well be true as it applies to Twitter and You Tube, not so with WhatsApp. With the latter, the relationship goes in the line of association, social groups, Age Grades, Club members, kindred and village groups, where educational levels vary, as well as elites where colleagues create groups of common interest. Thus, reasoning and cognition levels tend to affect the interaction as tempers may flare, to be controlled by the more enlightened and mature members. Also, Facebook, on its part is an open sesame to whoever has Internet access and can afford data and does not necessarily follow lines or groupings on the basis of literacy. These two platforms more than any others, that is, Whatsapp and Facebook, are the agents of citizenship liberation from the shackles of professional journalistic monopoly. They are, therefore, the major causes of the communication vices referred to in the title/topic of this paper. At one level, they have come to liberate the citizens and release the muted voices from their mute mode. At another level, they have come to abuse and make nonsense of professional journalism practice by the ignorance and poor knowledge of journalistic ethics exhibited by the citizens and users. Social media are therefore, the catalyst to citizen journalism and the bane of professional journalism in present day world of global-village-cities of modern man and digital communication in Nigeria at least.

Taking his definition from an online source, Udenze, (2018, p. 119) sees WhatsApp as "a freeware, cross-platform and end-to-end encrypted instant messaging application for smart phones." He goes on to that it "uses the internet to make voice calls, one to one video calls; send text messages, documents, PDF files, images, GIF, videos, user location, audio files, phone contacts and voice notes to other users using standard cellular mobile phones," (p. 119). WhatsApp, from the above definition, can be seen as social media platform that is quite a communication force to be reckoned with in terms of virtually any desired mode of communication to which the user wishes to deploy it.

\section{Before the Advent of Social Media in Nigeria}

The Nigerian press, dating back to the year 1859, can be said to have seen and experienced the best and worst of journalism practice, having contended with the colonial government which introduced it, then with the various military regimes with their autocratic tendencies and now, the Nigerian/African brand of democratic governance. In all these, the press can be said to have acquitted itself well. Indeed, the Nigerian press was reputed to have been instrumental to the attainment of independence (Duyile, 1989; Mabadeje, 2004) as well as a key player in the death of the first republic as the military found the attractions inherent in broadcasting and zeroed in on it as an agent for its own recognition as well as for disseminating information (Udeajah, 2003). The post-colonial/independence era saw the press 
undergoing several challenges in its desire to achieve a society that is free from all forms of restrictions to free speech. The journalist in his various functions as reporter, writer, editor, etc. was the be all and end all in all matters of news coverage, from sourcing to disseminating.

Armed with the professional code of journalistic ethics as his constitution, he deployed his expertise by following the standard procedure of news coverage. The selective process, also called the selectivity theory (Nwanne, 2008) gave him the right to selective perception, selective exposure, selective attention and selective retention. Though the journalist was the judge and determiner of what news gets to the audience/public, he was prone to follow the hierarchy in the news process from gathering to reporting. He recognizes and follows the constituents of news such as prominence, timeliness, accuracy, fairness/objectivity, human interest, among others. The field reporter and other categories of journalists were answerable to the editor who gave the final approval of what information finally got to the reader/ listener/viewer. Even when there is live coverage, the reporter was conscious of the journalistic code as well as the dictum that says, "All that airs must be edited." There were checks and balances and self-censorship which saw to it the journalist was neither flippant nor arrogant. He stayed within the bounds of decency, conscious of public interest, national security, and avoiding as much as he could, getting on the wrong side of the powers that be. In spite all the efforts at being fair as much as possible to all concerned, the journalist was still susceptible to the charge of being biased on the basis of the fact that what the public sees, hears or reads as news is the aspect and viewpoint the journalist chose to report. Thus, he is the defender, prosecutor and judge of what constituted news and how it is handled.

The power of the journalist to determine what news gets to the public has corresponding responsibilities. He was to ensure fairness in all his dealings by making sure all segments of the society get their fair share of representation in all matters of information coverage and dissemination. Of course, it goes without saying that he may from time to time, consciously or otherwise, default in carrying out these duties.

Thus, the activities of women in society are not given much attention, except where such women are significant social actors (e.g., the First Lady), or where some women have done or are suspected to have done something that the male-dominated society had not expected from "women", (Oha, 1999, p. 14).

The procedural nature of news gathering and processing naturally creates room for allegations of bias and subjectivity in handling of information. Many a time, the rural areas are neglected while attention is focused on the cities. Also, the government of the day does not only interfere, but it also inclines towards controlling the media. Again, the sensitive nature of the journalistic profession makes it imperative that the practitioner must not only be protected against the powers that be, he must be protected against the public for whose sake he is risking his life and also be protected against himself for his own good! The importance of journalists' reliance on the code of ethics was underscored by Folarin when he cites Merrill: 
...it brings the matter of morality to the individual person; it forces the journalist, among others, to consider his basic principles, his values, his obligations to himself and to others. It forces him to decide for himself how he will live, how he will conduct his journalistic affairs, how he will think of himself and of others, how he will think, act and react to the people and issues surrounding him (1999, p. 47).

The above submission clearly shows that the journalist does not only have to consider himself in his business of information gathering, transmitting and dissemination, he must also have in mind the other stakeholders such as the government and the public, his main focus since his central concern is usually the publics' right to know. The journalist's desire for the right of the public to know leads him to go beyond mere news reporting. As Okigbo, cited in Okunna (2003, p. 77) makes us understand, "telling the news is not enough." She continues, "journalists should go beyond telling the news and aim for the active involvement of the community through analysis, interpretation, evaluation and interaction." Called civic journalism, community journalism and recently, citizen journalism, the purpose of citizen journalism is "not just to tell people what the government says and does, but it should also encourage citizens to talk about their own expectations and what they feel about issues" (p. 77).

Civic journalism or community journalism was as originally conceived designed for the professionally trained journalist to report news and interpret news from the point of view of the citizens with a view to encouraging them to bare their minds on issues which are of relevance to them. It was not designed for citizens to wrest the entire news and information gathering and dissemination process from the professionally trained practitioner and invest such rights on the citizens. Unfortunately, this is the case with social media oriented citizen journalism. The social media have come as it were, to break the monopoly of the entire business of news and information gathering, processing and dissemination, from the professionals and invested the rights to the citizens to the point that the latter are on the verge of driving the former out of business and taking on the responsibilities, warts and all, and foisting them on the people and the government. It is so bad that the professional journalist and even the government are fighting to regain the glory of the halcyon days of professional journalistic practice that believes in the sanctity of journalism code of ethics! The reason is that citizen journalism has become a necessary evil that forces government to respond and act on issues which it would have otherwise ignored or sanctioned in the 'era' of conventional journalistic practice. Let us examine how this comes about.

\section{Social Media and Citizen Journalism}

The writer's overall perception and attitude to information from social media can be likened to the attitude of the German historian and publicist, August Von Schlozer (1735-1809), when he said, "foolish is the man who never reads a newspaper and even more foolish is the man who believes what he reads just because it is in the newspaper," (Toluna Influencers, 2018). The above statement can be rephrased by substituting newspaper for social media. One can then say that 
foolish is the person who does not use social media (any of the platforms), and even more foolish is the person who believes what s/he reads/sees just because it is from social media. By this, one is saying that every information from any social media platforms should be treated with a pinch of salt until credibility is established before belief. At least, another source should substantiate whatever the social media offer before it can be taken seriously.

Sometimes called public journalism, the idea of citizen journalism, from inception, "is to frame stories from the citizen's view, rather than inserting man-inthe-street quotes into a frame dominated by professionals," (p. 509). The authors continue:

- It moves beyond the limited mission of "telling the news" to a broader mission of helping public life go well, and acts out that imperative....

- It moves from detachment to being a fair-minded participant in public life....

- It moves beyond only describing what is "going wrong" to also imagining what "going right" would be like....

- It moves from seeing people as consumers- as readers or non-readers, as bystanders to be informed- to seeing them as a public, as potential actors in arriving at democratic solutions to public problems, (Campbell et al. 2009, p. 508).

The noble intentions which saw the emergence of citizen/public/civic journalism have been no doubt eroded by the evolution of social media. With social media, citizens are no longer contented with being represented or their opinions sought. They have taken the bull by the horns, overthrown the professional journalist and have taken on the entire news production and dissemination process, warts and all; foisting their views on all and sundry and leaving the professional journalist and media practitioner trailing behind. Whereas, the professionally trained journalist was sensitive and mindful of public sensibilities and decency, the citizen journalist represents the very opposite of the professional. As was captured by the Clerk in Marie Corelli's novel, The Sorrows of Satan, 'there's nothing like journalism, sir, for the suppression of truth!" (Corelli, 2006, p. 157). One can paraphrase the statement by observing that there is nothing like citizen journalism through the use of social media in exposing the truth! The citizen is propelled by several factors, not least, emotions/sentiments to report the news and disseminate it as he sees it. It is a highly subjective method of journalistic practice.

\section{Factors that Influence Citizen Journalism}

The average Nigerian lives and is inundated with myriad of insecurities and social challenges. He is conscious of the insincerity of governments at all levels so his distrust of government actions and policies is palpable. Arising from this, even the best intentions of government are suspect. His distrust of government at all levels is as a consequence of his daily experiences via his observations of the 
lifestyles of political office holders which are not salutary. This is because the lifestyles of the politicians and party leaders make citizens to suspect their claims of sincerity and this distrust cuts across the geographical wind vane of the nation without recourse to ethnic or religious sentiments and rubs off on citizens a belief or rejection of government directives. To that end, our interactions with members of the Whatsapp Groups reveal the following factors as influencing citizen's initial response to whatever goes on around him and drives his overall attitude to citizen journalism.

- Unemployment. The average Nigerian is aware that job creation by government is media hype that does not translate to reality. You hear of job creation and empowerment, and like claims of miracle by some pastors you never know or get to see any of the beneficiaries of such healing until the scam is exposed for what it is.

- Insincerity. This is on the part of Nigerian government which through its officials engages in doublespeak thereby leaving people to respond with their varied understanding; interpretation and response. This complicates issues as it makes people take to their various social media outlets with their perceived understanding.

- Frustration. The said insecurities coupled with the absence of basic amenities in the areas of water, light, good road networks, security and the attendant police brutality, among numerous others unlock the tongue and unleash various protestations which manifest in posts on social media.

- Mischief making. Some people cannot resist the joy of pranks; some go out of their way to test their popularity through fake information (a good number of youths are guilty of this), some also do it out of sheer ignorance.

- Idleness. The saying that an idle mind is the devil's workshop became more apparent with the global lockdown occasioned by the corona virus (Covid-19) pandemic that was said to have originated from China's Wuhan Laboratory. The lockdown which prevented people to leave their homes created an escape for them through social media. The consequence is an avalanche of information and misinformation, fake news, all manners of fabrication and mischief making purportedly geared towards relieving people from the boredom of lockdown. The effect is confusion as there are more "Doctors" prescribing solutions than the disease itself.

- Injustice. When people perceive what the government is doing or about to do as biased or unjust, they quickly react. Some times their reaction helps to nip such action in the bud and forestalls it. The Covid-19 pandemic has shown this to be the case in Nigeria. For example, the death of President Muhammadu Buhari's Head of Service to the Government of the Federation, Mallam Abbah Kyari on the $17^{\text {th }}$ of April, 2020, has revealed this to be true. Information went viral on social media (Whatsaap), alleging that the Imo State governor, His Excellency, Senator Hope Uzodimma, said that because the late Abbah Kyari made him the governor, he, Hope Uzodimma, was going to immortalize him by renaming the state owned university after the late Abbah Kyari. No sooner was this information 
circulated than the governor deployed both social and traditional media to refute the claim.

- Humorists: There are also those who make the social media bubble with their creativity. This group competes with the professional stand-up comedians in making fun of everything. The most serious issues of governance, private and public engagements serve as avenue for poking fun and this covers all the social media platforms and no subject is sacred. This group helps the ordinary citizen keep hope alive by giving him reason/cause to smile through its creative ingenuity.

- Personality Stalkers. There are those who spend time and money stalking renowned personalities on the internet and social media. They are what Nigerians refer to as "monitoring spirits." Their intentions are neither noble nor uplifting, rather, they manners of speech and writing; they then write all sorts of things and attribute study these personalities' styles and them to the said personalities. Some make money from it while others derive joy from such misinformation. You only get to know that the information is not credible by either contacting the affected personality or studying the content which must inevitably have grammatical, spelling or tenses blemish.

- Advertisements: With the Covid-19 imposed lockdown, people device and innovate ways of making ends meet. Many undergraduate students have taken to blogging, to petty trading, and others to whatever product catches their fancy, all in a bid to combat idleness and be relevant. Whatever the engagements may be, they must be advertised and social media provide ready and available outlets.

These are some of the causes of citizens taking to social media to express themselves. The reasons are of course, not exhaustive and cannot be exhausted in a single paper. This work can, however, engender subsequent works on the subject.

\section{Research Method}

The research method adopted is the participant observation. The researchers belong to various Whatsapp chat groups from where they drew their primary data by way of posts and reposts as they appear in the group and also reactions of group members provided further insights. The screenshots used here as primary data were all from the various Whatsapp Chat Groups to which the researchers belong. The materials were therefore in the public domain. Some may have been originally posted on other social media platforms such as Facebook, Twitter, Whatsapp and the like. But the ones used here were from all from Whatsapp. 


\section{Oxymoronic Relevance of Social Media and their Contributions to Development}

Oxymoron is one of the literary devices (figures of speech) which creative writers use to add style and beauty to their work in order to enrich such work. Figures of speech are usually referred to as ornaments of literary language because they are used to beautify creative works such as poetry, drama and prose. Oxymoron is a figure of speech which uses two opposite or contradictory words to reveal the truth (Nwachukwu-Agbada et al., 2014, p. 5); for example "a beautiful witch." In this paper, the oxymoronic relevance of social media use in Nigeria refers to the fact that social media are supposed to be deployed by Nigerian citizens to address issues of concern to the citizens, the society and the government for the well-being of all the stakeholders. Unfortunately, this is not the case as the social media are instead being used for and against everyone, including the citizens themselves. Examples can be seen from the plethora of information and misinformation which emanated from the citizens with particular emphasis on the covid-19 pandemic. Based on the foregoing, one can therefore, submit that the social media use in Nigeria from the point of view of citizen journalism is in oxymoronic terms, harmfully beneficial. Their ability to elicit response from the government and other authorities is decidedly positive and a good development.

We now turn our attention to examples drawn from Whatsapp Chat Groups to illustrate how social media engender and contribute to development. The examples are randomly taken from information from the said groups as they are received. Where necessary, the information would either be paraphrased or reproduced verbatim and then analyzed in line with the focus of the paper. The screenshot below is self-explanatory. Needless to say, there were claims and counter claims between the Nigerian army and the public.

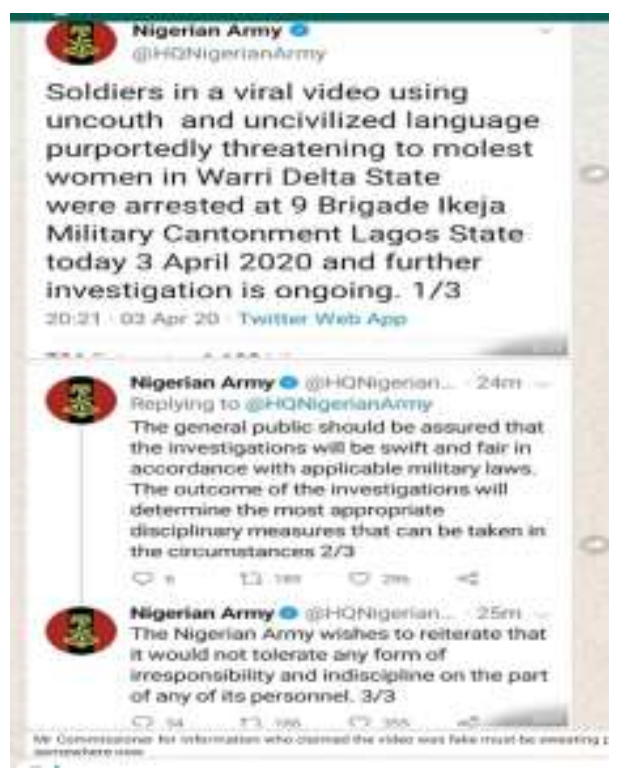

The average Nigerian lacks faith in the government to the point that even when the information above was confirmed as true nothing else happens. The 
good thing was that there was response from the accused; whereas in the past the release of the video would have meant a manhunt for the "bloody civilian" that dared point fingers at the army. The relevance of social media to the Nigerian masses can be likened to the cries of a chick in the hugging death embrace of a hawk. The cries are not for help (the chick is beyond help at this point), rather, they signify a plea for the world to take notice. The Nigerian masses are the chicks to the political and power-monger hawks. Therefore, if the chick's cries elicit positive reaction from the hawk, so be it. That is exactly how the social media function and it is good for the society because before now, voices of protest or of complaint were either muted by conventional media through the news selection process or when carried, was simply ignored by the government as irrelevant, insignificant or unimportant and therefore of no effect. This is substantiated by Graber in the third edition of her book, Mass media and American politics, when she says, "without media attention the people and events covered by the news might have no influence, or reduced influence, on decision makers. Conditions that may be tolerated while they remain obscure may quickly become intolerable in the glare of publicity," (Graber, 1989, p. 6). In the bid to avoid the unpleasantness generated by information from social media, the government is forced to respond to douse tension.

\section{THE UNENDING CRISIS.}

Goodluck Jonathan Speaks From US- Why Niger Deltans Do not Want To Be Part Of Biafra

Former President of Nigeria, Goodluck Ebere Jonathan yesterday delivered a lecture at Texas US on why remaining indivisible with Nigeria than joining forces with Biafrans in splitting the country will pay niger deltans more.

I begin this write-up by saying that I mean no ill-thought towards the Biafran struggle or Igbos in general. What I've written here are mainly my personal reflections concerning the Niger Delta, especially with regards to non-lgbo groups and their stake in the Biafran movement which has been rebirthed for some time now. I am not a mouthpiece for the Niger Delta but I believe I've been in the Niger Delta long enough to know our problems and our stand. I've also interacted with many Niger Deltans to know their stand in the Biafran struggle.

When I use the term Niger Delta, I am referring to the region covering Delta, Edo, Bayelsa, Rivers, Akwa Ibom, and Cross River states. However, I understand that the region also covers Ondo, Imo, and Abia states. I'm not concerned with the latter because they are either Igbos or Yorubas and have their own struggles. The ethnic groups within my coverage include Urhobo-Isoko, Bini, Esan, Itsekiri, Ijaw-Epie-Ogbia, Ogoni, Afemai, Efik-Annang-Eket-Oron-Ibibio, Ogoja, Ejagham, and other groups in Cross River North. Ikwerre, Ukwuani, Ika, Aniocha, Ogba, and other Igboid groups, are not included. Historically, Biafra covered all the Niger Delta states EXCEPT Delta and Ondo states. This fact must be emphasised.

Pro-Biafrans are welcome to debate and address my issues in a civil manner. I understand that most pro-Biafrans resort to insults when salient issues are addressed.

Recently, there was a claim alleging that the former President, Goodluck Ebele Jonathan was in Texas, USA, where he gave a lecture in which he was said to have made references dissociating the Niger Delta from Biafra agitations and similar claims. His media adviser, Mr. Ikechukwu Eze refuted the claim observing 
that the former President was not anywhere near USA, let alone Texas and could not have given any lecture or sent a representative. See screenshot above.

Former Nigerian President, Goodluck Ebele Jonathan has disowned an online statement credited to him concerning the relationship between the South East and the people of the Niger Delta, describing it as a fabricated speech.

The report claimed that the former President spoke on the position of Niger Delta over agitations for Biafra in a speech he presented recently in Texas, United States.

However, a statement signed by his Media Adviser. Mr. Ikechukwu Eze, on Saturday described the report as false, declaring that the former President could not have presented the purported speech because neither did he travel to the United States nor send anybody to represent him at the unnamed event

Eze who noted that it was the second time in three years that the former... Read more

The two screenshots above show the originating story and its counter. For an average person, such information attributed to such personality cannot but be credible. When such information is refuted by the person, the receiver becomes thoroughly confused.

The Corona virus (Covid-19) pandemic raving the globe has created further avenue for the citizens to question the credibility and sincerity of the government with claims and counter claims ranging from figures of infected victims to whether the virus is real (see also, Ademiju-Bepo 2020).

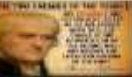

Barom rooy

The Trargedy called Wigeria a The Kano state gavernot news the Coronavirus as follown 1 . competition with La
wob facebooks com

The Tragedy called Nigeria 3

The Kano state governor sees the Coronavirus as followa:

1. A competition with Lagos

2. A means to corner resources.

Immediately it was announced that there was $450 \mathrm{~m}$ from the $\mathrm{EU}$, Gandollar went into action And his numbers started inoreasing from like 3 to more than 200 in a few daya. Lol. Now he'a asking for "d seread it" maybe that's why he deported over 100 almajiri kids to digawa but I digress

In Nigeria, the citizens are angry because the federal government and some state governments have turned the pandemic into a money-spinning enterpriset The NCDC is VERY culpable in this. The numbers are $E 0$ tragically fraudulent that the UN and WHO almost directly referred to the Numbers from Nigeria as pure soant

Let me shock you a bit some of the sick alleged to have Coronavirus had flu or malaria, but they are added to boost the numbers!

it's all about the budget?

See the following, all on the news:

MS measeges on Coronevirue

2. Fderat ministry of humanitarian affairs spends 72 bn in 24 hrs as palliatives for Coronavirusd 3. A state government in the North spends 2 billon Naira to "dig" graves in anticipation of deathe

4. The Nigerian Militury spends $10 \mathrm{bn}$ for Military Isolation centres on Coronavirua

These are just a fow. In the US and they're moving mountains to solve the problem of the Coronavirus, in Nigeria however, it's a business enterprise. The citizens are left to die of the Coron itself

If we had a parliamentary system where every dime would and decision would be bickered over, the far more useless than the "P" in the word "psyohology"l so anything goes; the down, and the government officials empty the Treasuryl No consequencest How on earth does a country achieve sanity that way and develop? Little Ghana next door is showing the world how to helve probleme bot thie diant iatot de dermined to enen

Nigeria is a tragedy.

\#thinkAgain

\footnotetext{
${ }^{2}$ All the screenshots used here were taken from the Whatsapp Groups monitored. Some of them may have appeared in other social media such as Facebook, Twitter, etc. but they were reposted on Whatsapp hence their use here.
} 
The screenshot above is another forwarded post taken from a Whatsapp group chat. The information it contains documents the attitude of the Federal and state governments to the corona virus pandemic. It represents the majority of what the citizens think about the disease which makes it difficult for the majority of them to identify with government position on social distancing, lockdown, use of facemasks, etc.

It has been mentioned earlier that social media foreshadow the action and inaction of government thus putting the government on the defensive and using conventional media to authenticate or contradict the information. One such event played out recently when social media carried the news that Professor Ibrahim Agboola Gambari was the new Chief of Staff $(\mathrm{CoS})$ to the Federal Government, as a replacement to late Abbah Kyari. The information was immediately refuted by a source attributed to the presidency, only for the same news to be carried by a reputable private television in its news barely twenty four hours after thereby confirming the earlier claim.

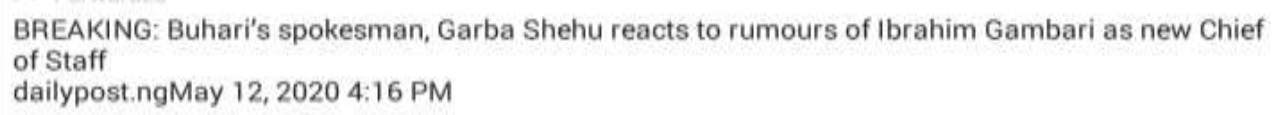

The Presidency on Tuesday reacted to reports that President Muhammadu Buhari has appointed a new Chief of Staff, Cos.

Reports on social media had it that Buhari appointed Prof. Ibrahim Gambari as his new CoS, following the demise of Abba Kyari.

When DAILY POST reached out to Buhari's Senior Special Assistant on Media and Publicity, Garba Shehu, the presidential spokesperson said he was not aware of such development.

In a text sent, Garba wrote: "I have not been briefed."

The views expressed in this article are the writer's, they do not reflect the views of Opera News Please report any fake news or defamatory statements to feedback-newshub@operanewshub.com

Report a problem

The above information made news headlines on the $12^{\text {th }}$ of May, 2020, and on the $13^{\text {th }}$ at its news at $8.00 \mathrm{pm}$, it was confirmed by Africa Independent Television (AIT). Sometimes, the reverse is the case and the conventional media blaze the trail and one has to search social media for further information. Perhaps, their ready availability makes social media the fastest information source for the citizens and even for the traditional news media. Whichever the case, social media, WHATSAPP in particular, puts the citizen a step ahead of what obtained in the past in terms of news availability, processing and dissemination.

For the Nigerian citizen, the lines between conventional media and social media in terms of news processing and dissemination get thinner by the day. It becomes very difficult to determine whether it is the social media dog wagging the conventional media tail or the reverse. Whichever may be the case, citizen journalism enables the citizen to be a participant in news creation and 
dissemination. The era of being sidelined or his voice being muted in matters of public affairs is over. As long as the government has not succeeded in passing any bill controlling social media use, the ordinary citizen has a say in governance. He is not successful in influencing decisions for or against all the time; but whenever he succeeds someone somewhere gets a new lease of life no matter how short lived. When he fails to, he nevertheless is able to send a message across and his voice of protest or support is noted.

Suffice it to say that social media have come to right the wrongs done against the Nigerian citizen by both government and conventional/professional journalism practice in terms of news coverage and information dissemination. Through social media, the citizens have taken the gauntlet and are now in the forefront of news creation for whatever it is worth, warts and all. They do not care who is listening but they are aware that someone somewhere is listening. They do not care about ethics or are affected by professional news procedure, their news and information manufacturing and dissemination can best be described as "being on the go and as it occurs to the sender."

\section{Results}

The following, among others, are the findings of this study.

- It was observed that social media platforms especially Whatsapp serve as an avenue for citizens to express themselves. This is done through graphicsprint; video and audio as well as voice recordings.

- Information/news from social media has credibility problems. One needs to seek several information sources in order to authenticate such information/ news before accepting it.

- Social media create doubts in people's mind about the veracity of news from conventional news media by being ahead of them with the news,

- Social media sources lack professional media ethics and thus disseminate news and information as it comes.

- Governments pay attention to news from social media and react to them on the basis of their weight; examples are the burial of Abbah Kyari and the appointment of Professor Ibrahim Gambari as his replacement. In the former, government apologized to the complaint of the citizens in the abuse of social distance while in the latter, it reversed itself by the appointment after initial denial of it.

- Social media, in most cases, are ahead of conventional media in news and information dissemination.

- Social media help the citizens get along by providing comic relief through their posts; they also complicate matters by posting information that creates tension. 


\section{Conclusion}

Before the advent of social media and to a certain extent even now, the journalism profession is regarded as noble and many people if they had their way, would have loved to be in it. The reason is obvious: when the journalist speaks, everybody, without exception, listens. The internet with its social media platforms has eroded and undermined the journalistic profession by turning whoever has android phone and can afford the cost of data to a journalist of sorts. Thus, we have the citizen journalist that is an entire media house, - electronic and print,- all rolled into one, being source, reporter, photographer, camera man, proof reader, editor, etc. The citizen has found his voice and it rings out from all the seven heads of Hydra ${ }^{3}$ causing confusion and sometimes, making sense. The good thing is that when it makes sense, the powers that be respond. This response is for the benefit of all whether it is for better or worse, it signals the fact that the voice was heard.

The paper has therefore, examined the way the masses respond to their government through the use of social media with specific focus on selected Whatsapp Chat Groups. The involvement of citizens in information and news processing and dissemination is altogether a good development as it creates room for selfexpression and in some way involves the citizens in governance. Though, it is a good development, it ought to be done with caution as it has a great tendency to confuse. It is however, bad and irresponsible government that creates room for the citizen to become a critic of sorts because when doubts are created in the minds of people, credibility and trust are lost. For instance, the insincerity of government in the fight against the corona virus pandemic is underscored by resident doctors being on strike action in the heat of the pandemic. Also, the lip service which government pays to education is equally undermined by the Academic Union of Nigerian Universities (ASUU), being on strike since the beginning of the lockdown. This singular act of strike action makes nonsense of government directive that Virtual learning be commenced to engage the students meaningfully during the period. Moreover, the facilities for actualising it like the commonest denominator, which is the provision of electricity are completely lacking. All these combine to provoke the citizens to take to social media to express themselves.

\section{References}

Ademiju-Bepo, A. (2020). Bepo writes: like IPPIS, like Covid-19: government is right. Retrieved from: http://www.viewpointnigeria.org/bepo-writes-like-ippis-like-covid19-government-is-right/. [Accessed 18 May 2020.]

Adeseye, F., Ibagere, E. (1999). Communication and man: a theoretical base for the student. Akure: Ola-Olu Enterprises.

Campbell, R., Martin, R. C., Fabos, B. (2009). Media and culture: an introduction to mass communication. Boston: Bedford/St. Martin's.

Corelli, M. (2006). The sorrows of Satan. New York: Elibron Classics Series / Adamant Media Corporation.

\footnotetext{
${ }^{3}$ Hydra in Greek mythology was a giant water snake that lived in a swamp near Lerana in the land of Argos. The number of heads is reported variously as few as 5-100. (Retrieved from: encyclope dia.com/litera ture-and-arts/classical-literature-myt. [Accessed 2 June 2020.]
} 
Duyile, D. (1989). Media and mass communication in Nigeria. $2^{\text {nd }}$ Edition. Lagos: Gong Communication, Nigeria Ltd.

Folarin, B. A. (1999). Mass media ethics and the Nigerian journalist. Journal of Communication and Language Arts, 1(1), 45-57.

Graber, A. D. (1989). Mass media and American politics. $3^{\text {rd }}$ Edition. Washington: Congressional Quarterly Incorporated.

M'Bow, A. (1981). Foreword. In Many Voices, One World. Ibadan. Ibadan/Paris: University Press/UNESCO Press, xvii-xx.

Mabadeje, I. (2004). The Nigerian press under the military: a compendium of cases of press freedom violations in Nigeria (1966-1999). Uyo: Robert Minder International.

MacBride, S., Commission (1981). Many voices, one world. Ibadan/Paris: University Press/ UNESCO Press.

Nwachukwu-Agbada, J. O. J., Omobowale, T., Ododo, S. E., Adebiyi, K. (2014). Exam focus: literature-in-English 2016-2020 for WAEC (WASSCE) AND NECO (SSCE). Ibadan: University Press.

Nwanne, U. B. (2008). Essentials of news reporting and writing. Lagos: Broada Ventures.

Oha, O. (1999). News reporting and environmental protection in the periphery nation. Journal of Communication and Language Arts, 1(1), 11-19.

Ojebode, A. (2018). Fake news, hate speech and the redemptive role of the Nigerian media. Being Text of the $13^{\text {th }}$ Annual Federal Radio Corporation of Nigeria (FRCN), presented at NICON Luxury Hotel, Abuja, Nigeria, $29^{\text {th }}$ November, 2018.

Okunna, C. S. (2003). Ethics of mass communication. $2^{\text {nd }}$ Edition. Enugu: New Generation Ventures, Ltd.

Omosotomhe, S., I., Olley, W. O. (2018). Utilisation of social media for news gathering and dissemination in Edo State, Nigeria. The Nigerian Journal of Communication. ACCE, Nigerian Chapter, 15(2), 375-390.

Oxford Dictionary Thesaurus \& Wordpower Guide (2001). Oxford: Oxford University Press.

Rasmussen, J., Ihlen, O. (2017). Risk, crisis, and social media: a systematic review of seven years' research. Nordicum Review, 2(38), 1-17.

Talabi, F. O., Adaja, T. A., Adefemi, V. O. (2018). Publish or perish versus publish and perish: the sanctity of communication and academic paper publications in the era of predatory journals. In D. Wilson, H. Batta (eds.), Communication Education and Research in $21^{\text {st }}$ Century Nigeria. Uyo: African Council for Communication Education, Nigerian Chapter, 1-13.

Udeajah, A. R. (2003). Broadcasting and politics in Nigeria: 1963-2003. Enugu: SNAAP Press, Ltd.

Udenze, S. (2018). Whatsapp: an alternative to SMS. New Frontiers: A Journal of the Humanities, 2(1), 117-127.

Uzuegbunam, C. E., Omenugha, N. O. (2018). Mainstream media, social media and peace-building in Nigeria: old challenges, new opportunities? The Nigerian Journal of Communication, 15(2), 519-534.

Verbood, M., van Noord, S. (2016). The online place of popular music: exploring the impact of geography and social media on pop artists' mainstream media attention. Popular Communication, The International Journal of Media and Culture, 14(2), $59-72$.

Von-Schlozer, A. Retrieved from: https://us.toluna.com/opinions/2970266/Lies-Follish-isthe-man-who-never-reads-a-newspaper. [Accessed 8 May 2020.]

$\mathrm{Xi}, \mathrm{L}$. (2017). Praxis and theory combined: introduction to "new perspectives on new media." FUDAN: Journal of the Humanities and Social Sciences, 10(3), 273-279. 


\title{
Reality Crime Programs in Turkish Television: The Notorious Case of Palu Family on Müge Anlı
}

\author{
By Tuna Tetik ${ }^{*} \&$ Dilay Özgüven ${ }^{ \pm}$
}

\begin{abstract}
The crime drama has always been popular on radio and television. Following this popular programming type, these programs found its way into reality crime programs. The reality crime programs emerged in U.S television in the late 1980 s as the combination of news, crime dramas, and even horror genre. The reality crime programs placed themselves mainly in two formats in the television world. There is a vignette format where actors reenact actual crimes, and another one is the live-action format. It is the 1990s for Turkey to introduce reality television to the audience. One of the popular programs that were first broadcasted on ATV in 2008 hosted by Müge Anlt is the Müge Anlt ile Tatl Sert. After we discuss the popularity of the reality crime television and the cases from American television, MATS is discussed as a certain criminal case from Turkey. This case is publicly recognized as Palu Family. This article argues how the case of the Palu Family became a televised public psychosis in MATS which is a hybrid reality crime program. With this regard, we will study family violence, sexual abuse, and homicide that have become publicly available to the audience.
\end{abstract}

Keywords: reality TV, reality crime programs, infotainment, crime, Turkish television, Müge Anl1

\section{Introduction}

On 21 December 2018, a family attended to a Turkish television program called Müge Anll ile Tatl Sert, claiming that two of their family members are missing for ten years. Later it was discovered that this family is involved in the murder of two members and also it has come to light that there are abuse, violence and drug use within the family. This case was solved on the live broadcast and became one of the most terrifying stories in Turkish television. With the impact of the program, many authorities got alarmed and started taking action against this case. In this article, we will analyze this case and identify the format of the program Müge Anlı ile Tatl Sert along with it.

Our main argument in this article is to define Müge Anll ile Tatll Sert as a hybrid reality crime program and discuss the case of the Palu Family within this context. Specifically, the case of the Palu Family is selected to analyze the uniqueness of Müge Anll ile Tatl Sert's format within the crime based-reality programs in Turkish television. We will begin with introducing infotainment as a new media content in television programming. Later we will discuss the genres

${ }^{*} \mathrm{PhD}$, The Graduate School of Social Sciences, Bahçeşehir University, Turkey.

${ }^{ \pm} \mathrm{PhD}$ Student, The Graduate School of Social Sciences, Bahçeşehir University, Turkey. 
and formats of television programming along with its hybrid feature. We will move on to reality television and define its subgenres and formats. Within the subgenres of reality television, we will focus on reality crime programs. We will give brief history of reality crime programs before moving on to its reflection on Turkish television. Before analyzing Müge Anlt ile Tatlı Sert as a hybrid crimebased reality program, we will define several features of reality television formats in Turkish television. Therefore, this article will include the process of the localization of U.S. television-based reality programs in Turkish television history. Then, this article's main argument will be based on the claim that Müge Anll ile Tatl Sert is a hybrid format, which has both features of a broadcasting crime and an investigation-based program. The program's specificity comes from the longterm hosting of Müge Anl, the program's impact on the unsolved cases, and the hybridity derives from information and entertainment-based formats. We will analyze the reality television history and place this program as a hybrid reality television program in Turkish television. The theoretical background and the literature include the reality in the media, the representation of the crime, the localization of the reality television in Turkey. We will conclude our statement with a specific case from Müge Anlv ile Tatl Sert to illustrate the features of reality crime programs in Turkey. The case is publicly known as the Palu Family case, which consists of a considerable number of types of criminal acts, including murder, theft, physical and psychological abuse, manipulation, fraud, and forgery of documents. The case of the Palu Family case in the Müge Anlt ile Tatl Sert has been broadcasted for two weeks. Due to the public response on the case, the high degree of rankings, and sensation created by the program, the case of Palu Family has occupied the agenda in Turkish television for two weeks. After defining the position of the Müge Anll ile Tatll Sert as an only hybrid crime-based reality program in Turkish television, the representation of the crime in the program and the unique way Müge Anlı as a host in the investigation of the case will be analyzed.

\section{Methodology}

The analysis of the article is constructed within the media studies. Specifically, the genre within the media content is reality television. To research the reality television genre, the analysis is conducted from the reality crime programs that have been broadcasted in Turkish television. The content analysis method is used to investigate a specific case called the Palu Family case from Müge Anll ile Tatl Sert to reveal the format's definitive features. The reason for analyzing MATS among other Turkish reality crime programs is that MATS is the most long-lasting reality crime program with the same host in the same channel in Turkish television history. The analysis is limited to examine the Palu Family case through fifteen days from 21.12.2018 to 11.01.2019. Therefore, from the beginning of the Paul Family case to the detention of the person of interest, fifteen episodes of MATS are detailed analyzed to describe MATS' format and its unique qualities. Television ratings determine the initial limiting factor for choosing the case. The article will 
demonstrate how the Palu Family case effects on MATS' ratings. Moreover, the Palu Family case is a perfect example to examine the MATS' hybridity that the case includes several types of criminal activities ranging from murder and missing person to fraud and theft that allow MATS to offer the audience both information and entertainment.

The study's hypothesis is grounded on the argument that Müge Anll ile Tatl Sert is a unique Turkish reality crime television program that can only be defined with its hybrid qualities. The hybridity is based on MATS' well-combined features, which come from other reality television formats in global and Turkish television. This study attempts to analyze which qualities of MATS allow us to define the program unique and hybrid. For that purpose, we ground the framework on this central research question of how MATS could be defined in the reality television genre? In line with this purpose, we will attempt to answer these questions: what is the position and uniqueness of MATS in Turkish television, and if we prefer to call MATS as a hybrid television program, which qualities become essential to define MATS within television studies' discourse. Theoretical background and literature review are based on media studies that are focused on the arguments on the history of the reality television genre, the representation of crime and criminal in media, the localization of reality television programs in Turkish television history, and the ancestor examples of MATS. Cavender and Fishman (1998), Surette (1997), and Breslin's (1990) seminal works on the representation of crime in global reality television are stated and give directions to the theoretical framework of the article. Notably, the arguments on Turkish reality crime programs in Turkish scholars' studies, such as Erol Işık and Yaman (2017) and Çelenk's (2015; 2011), enrich the section titled the localization of the reality television.

However, the literature, scoped researches on contemporary Turkish reality crime programs, is relatively limited in Turkish academia, because Turkish reality television programs, including crime-based reality programs, have been adapted from global television before MATS. As a contemporary example, MATS is a unique format that has not been officially defined and described yet. Thus, this study could contribute to the field because the analysis aims to define and examine the prominent example of a contemporary Turkish reality crime program through a specific case in Turkish television history.

\section{The Reality in the Media}

This section examines the history and types of the reality television formats in several media. For that purpose, the history of reality television and the literature of the television studies are revealed to discuss the specificity of Müge Anlı ile Tall Sert in the next chapters. There are four basic types of content in the media. These basic media content areas are advertising, news, entertainment, and infotainment (Surette, 1997: 15). Traditionally, news, entertainment, and advertising were sufficient to define the media content landscape, but today infotainment is a significant addition (Surette, 1997: 15). With the emergence of infotainment in the early 1980s, the aspect of news, entertainment, and advertising combined under a 
single umbrella. Thus, they are no longer separate media spheres 'due to infotainment's influence' (Surette, 1997: 19). Infotainment refers to a cluster of program types that blur the lines between information and entertainment genres of television programming. Especially, since the dominance of infotainment in television programming, hybrid formats of television programs started to appear.

A television program, or simply as a TV show, is any content produced for broadcast that viewed on television, excluding breaking news and advertisement. Television programs are more varied than most other forms of media because there is a wide range of formats and genres that can be presented. A television program could be categorized as fictional such as comedies or dramas and nonfictional such as documentary, news and reality television. For instance, as Cavender and Fishman (1998: 3) mentioned, "[g]ame shows and late-night talk shows (e.g., Letterman and Leno) are not fiction, but neither they are the news; they are entertainment programming". As Berger (1975: 3) mentioned; Television genres refer to a class of television programs and a given program is an example of that genre. The term genre comes from the French language and means type or kind. It is hard to place a television program in a single genre. Many television programs could fit into several genres. Furthermore, there is also a wide range of hybridity among the genres that causes a wide range of hybrid programs on television. It is impossible to deal with all the different genres and subgenres shown on television. There are several different genres of television programs competing with one another for viewers (Berger, 1975: 9).

A hybrid television genre on television programming is reality television. Reality television appeared in the late 1980s as a new trend hybrid television programming genre where the main subject is the representation of real people and reality. For Cavender and Fishman (1998: 3) "the defining feature of reality television is that these programs claim to present reality". It is certain that reality television according to Penzhorn and Pitout (2008: 62) focuses on ordinary people, voyeurism, audience participation, and the attempt to simulate real life. Reality television is about actual events and real people; "non-professional actors, unscripted dialogue, surveillance footage, hand-held cameras, seeing events unfold as they are happening in front of the camera" (Hill, 2005: 41). In reality television, there are different subgenres, such as hidden camera shows, home improvement shows, court shows or reality legal shows. Most of these subgenres have elements from other genres and formats of television programming. For instance, lifestyle formats, such as Changing Rooms, that contain stories of do-it-yourself (DIY) makeovers as well as ideas on interior design. One of the well-known reality game formats is Survivor where the show is about capturing "ordinary people in emotionally and physically challenging situations" (Hill, 2005: 8). Among the reality television genre on television programming, crime-based formats found its place on television. 


\section{The Representation of the Crime}

The aim of this chapter is searching different ways of the representation of the crime in media. The history of crime programming on television derived from crime drama programs on radio. Cavender and Fishman (1998: 8) stated "[m]ost histories of the media noted that television copied much of its programming style from radio". Many of the crime programs were based on novels and short stories and even dramatization of real police cases as radio crime entertainment. These broadcasts were cheap to produce and intriguing for the audience. In the 1930s a new type of radio program appeared. "Beginning with True Detective Mysteries, which described an actual wanted criminal at the end of each program, shows like Homicide Squat, Calling All Cars, and Treasury Agent dramatized real police cases as radio crime entertainment" (Stark, 1987: 241). This tradition of crime drama on radio has found its place in television programs. U.S. reality crime television started in 1987 when Unsolved Mysteries appeared as a pilot episode (Cavender and Fishman, 1998: 10). Following Unsolved Mysteries, America's Most Wanted aired on the new Fox network in January 1988. "The look of America's Most Wanted was a combination of 1940s films, MTV music videos, and gritty realism" (Breslin, 1990: 93-94). America's Most Wanted and Unsolved Mysteries quickly generated clones, including Cops (1989), Rescue 911 (1989), America Detective (1991), Untold Stories of the F.B.I. (1991), True Stories of the Highway Patrol (1993), and Crime-watch Tonight (1999). For instance, Cops and Real Stories of the Highway Patrols are marked as reality-based police shows. "While Cops is filmed live via a hand-held camera, Real Stories of the Highway Patrol involves reenactments of sensational cases, combined with some live footage" (Carmody, 1998: 164). A variety of hybrid television forms emerged in the 1980s and now popularly known as "reality TV". "Stories about crime - its nature, extent and resolution - have become routinized through repetitive and formulaic depiction in news and fictional entertainment forms" (Kohm, 2009: 193).

Reality legal show, which deals with subjects such as police, crime, and litigation, is a hybrid genre that borrows elements from documentary television, talk shows, news shows, caught on tape shows, and hidden camera shows. Among the reality legal shows, Cavender and Fishman highlight reality crime programs as "present true stories about crime, criminals, and victims" (Cavender and Fishman, 1998: 3). The reality crime programs are characterized between fact and fiction, and information and entertainment. Reality crime programs borrow several vocabularies from journalism such as correspondents or reporters. However, "the genre of reality crime is a long way from journalism. Program producers repeatedly step outside the bounds of accepted journalistic practice when they mix interviews of real victims and investigators with the reconstruction of events using actors" (Cavender and Fishman, 1998: 11). These shows include "crime reenactment, rescue and emergency reenactment, actual police action, home videos, entertainment news and magazine report" (Sholle, 1993: 56). These programs also combine "news, crime drama, and even elements of the horror genre" (Cavender and Fishman, 1998: 80). This format also 'emphasizes action, sets events to music, 
compresses time, speeds up the action and uses camera angles typical of horror films, action movies, or cinema vérité' (Cavender and Fishman, 1998: 12).

\section{The Localization of the Reality TV}

This chapter reveals the localization process of the reality programs in Turkish television and the effects on the U.S. based-reality television programs on the Turkish formats. The mixture of formats and genres borrowed from European television or American television emerged Turkish television. "Television format adaptations, in general, are foreign in terms of format, and the concern here is that this foreignness would lead to an estrangement and assimilation in content" (Çelenk, 2011: 139). The beginning of the 1990's new television formats and genres emerged in Turkish television. "Especially, the newly established private TV channels introduced several new programs, including TV series, game shows, reality shows, talk shows and live broadcasts, either locally or globally produced" (Kesirli, 2017: 91). Among these new types of entertainment programs hosted by celebrities as well as magazine programs and talk shows became especially popular on Turkish television (Kesirli, 2017: 43). The emergence of reality television in Turkey resulted in many improvements on television. For the first time in Turkish television history, "programs include live camera recordings, hidden camera recordings, amateur video recordings of events" (Binark and Kilıçbay, 2004: 74). These features also included "interviews with primary witnesses, slow-motion presentations of events, close-up shooting angles, and sound overlays on the event" (Binark and Kılıçbay 2004: 74). Following the emergence of these formats, a different and transitional format that combined elements from news and reality television can also be observed. This format also featured of the live broadcast of some police-judicial cases that develop during the day. Some examples of this format are, Yakn Takip (Close Chase, 1993), Olay Var (There is Incident, 1993), and Sicak Takip (Hot Chase, 1993) (Aksop, 1998: 89). These daily reality television programs were 15 -minute episodes that aired before the main news programs. Although these programs derive from real crime events, they are not journalistic but entertainment programming.

The first proper example of reality television and also reality crime program in Turkey is called Sicăğ Sicağına (In the Nick of Time, 1993) which was aired on private television channel Show TV on May 5, 1993 (Aksop, 1998: 91). The hosts of this new shows on Turkish television are often celebrities to draw the attention of the audience (Çelenk, 2005: 208). The first host of Sică̆ Sicağına was the Turkish actor Haluk Bilginer, later another actor Cem Kurtoğlu continued to host this program. The content of the program Sică̆ Sicağına formed around daily news of traffic accidents, demolitions, and fires. The use of visual effects, music, and reenactments aimed to draw the attention of the audience as well. This format resembles the vignette format of reality crime programs in which actors reenact actual crimes, and also feature "interviews with victims, their family and friends, the police, and film and photographs of suspects" (Cavender and Fishman, 1998: 79). In these vignettes, the mixture of reconstructions, the camera angles, 
music, lightning is used to enhance the dramatic and entertainment elements. (Surette, 1997: 22). After the success of Sică̆ Sicağına, several reality crime programs appeared on Turkish television in this format. Some examples of these are Söz Fato' da (Fato is Talking, 1993), Kayıp Aranıyor (Missing Person, 1997) and Devriye (Patrol, 1994) that aired on another private television channel ATV.

Among the following examples of reality crime programming on Turkish television, Söz Fato'da was hosted by actress Fatma Girik on private television channel Kanal D. The main issues in the program were murder cases, rape, incest relationships, drug use, fraud, corruption, etc. First few episodes of this program were using news from official police reports as cases similar to the format of Sicağı Sicağına. However, the following episodes were based on events that were reported by the audience via letters or personal applications. The program centered on the binary opposition between victim and perpetrator. Fatma Girik as the host became the guardian of the innocent victims within the male-centered television world. This format of crime programming became popular on Turkish television. In the 2000s the crime programs have a place in Turkish television that most of the private television channels have created a program similar to this format. Some of the popular examples of these crime programs are, Kadinin Sesi (Voice of Women, 2008), Serap Ezgü ile Biz Bize (Serap Ezgü is with Us, 2005), Suç ve Ceza (Crime and Punishment, 2010), Sizin Sesiniz (Your Voice, 2007) and others which began to focus on cases of missing people or other domestic issues including violence within the family. "These television programs have been presented by female hosts, who portrayed themselves as strong, determined, courageous, protective and heroic ways" (Erol Işık and Yaman, 2017: 73). The hosts of these reality crime programs are celebrities and mostly women. These programs combined elements from reality crime programs, court shows and formed into hybrid television programs.

Among several hybrid reality crime programs on Turkish television, we will analyze the program Müge Anlı ile Tatl Sert (Sweet and Sour with Müge Anli). The host of the program is Müge Anl who is an ex-magazine reporter. After presenting the news magazine program Dobra Dobra (2006), she started her own program Müge Anlı ile Tatlı Sert (MATS). This program was first broadcasted on ATV in 2008 and still continues to air every weekday from 10:00-13:00. This program is the only program on Turkish television that has been on air since 2008 and still going on. The program's format, airing time, and channel have not changed since 2008. The consistency of this program is one of the major reasons for our analysis. In MATS, Müge Anlı as the host focuses on the unsolved criminal cases, such as murder, fraud or kidnapping. "The program also presents itself as a service provider for those victimized due to the actions of others. From time to time, the producers of the program collaborate with the police authorities to find missing babies, children, teenager and even adults" (Erol Iş1k and Yaman, 2017: 73).

According to Kazaz and Bayar (2019: 187) the programs such as Balçiçek Ilter ile Olay Yeri (Crime Scene with Balçiçek İlter, 2017), Gerçeğin Peşinde (After the Truth with Serap Ezgü, 2017), and Müge Anlı ile Tatlı Sert (Sweet and Sour with Müge Anl1, 2008) resemble court shows in global television programs. The reason 
they resemble court shows is that they mimic the court-room format with discussion-based editing (Kazaz and Bayar, 2019: 187). Also, in these programs, there are lawyers, psychologists and sometimes forensic experts are invited. For instance, in the MATS case, the participants are victims, relatives of the victims, witnesses, eye-witnesses. Along with participants, there is a psychiatrist; Prof. Dr. Arif Verimli, a forensic scientist; Prof. Dr. Mehmet Şevki Sözen and attorney; Rahmi Özkan is present in every episode. Also, reporters sent to the crime scenes and live videos broadcasted from the scene. MATS is a hybrid reality crime program. While this program has several elements of reality crime programs, it also contains elements from court shows as well.

\section{The Case of "Palu Family"}

We will analyze the case of Palu Ailesi (Palu Family) and discuss the format of the program Müge Anl ile Tatl Sert within this case. We have chosen the case of Palu Ailesi (Palu Family) to study in this article. The first reason is that this case which involved, murder, sexual abuse, family violence, and several other issues that have happened in a single family was closed by Müge Anlı and her team. The second reason is, this case was so violent and striking that among many cases Müge Anlı took in hand, this specific one was known throughout the country. "This is not only a reality show, but this is also the visual example of all problems we deal with our country's legal system" wrote Deniz Zeyrek who is a journalist of a local newspaper in Turkey. We will analyze the evidence that Müge Anlı revealed on the show, and also discuss the MATS' format along with it. The participation of the members of Palu Family in the MATS and the interrogation by the host constitute the informative and investigate side of the program.

Among the family members, İsa Palu, son of Harun and Havva Palu, called the program to report that her sister Meryem Tahnal and her daughter Melike Tahnal is missing for ten years. After the prior notice of İsa Palu, Müge Anlı started her investigation process by inviting the victim's relatives, witnesses, and suspects to the program. The Palu Family attended to MATS on 21 December 2018 for the first time till 9 January 2019. Harun and Havva Palu have five children respectively; Fatih, İsa, Emine, Ayşe Melek, and Meryem. The first family members that appeared on the program were mother Havva Palu, and her two sons, İsa Palu and Fatih Palu. They claimed that Meryem Tahnal and Melike Tahnal are missing, and they also claimed that they do not know what happened to them. The first evidence of Müge Anlı was the testimony of Havva Palu. Havva Palu testified to police in 2011 that her son-in-law Tuncer Ustael caused the death of her daughter Meryem Tahnal and her grand-daughter Melike Tahnal. However, on MATS when Müge Anlı confronted Havva Palu about her testimony, she refused it.

Along with Müge Anlı, Prof. Dr. Arif Verimli, Prof. Dr. Mehmet Şevki Sözen, and Rahmi Özkan get involved in the process and started asking questions to the participants. As we have mentioned earlier, MATS has as a reality crime program has elements of court show format. Court shows in global television 
typically portray small claims court cases, produced in a simulation of a small courtroom inside of a television studio. The genre began in radio broadcasting in the 1930s and moved to television in the late 1940s, beginning with such TV shows Court of Current Issues (1948), Your Witness (1949), Famous Jury Trials (1949) (Murray and Ouellette, 2004: 227). The Turkish television did not adapt this format directly. From 2000s the reality crime programs have court room-like feature. To be specific, in MATS alongside with the host Müge Anl1, lawyers, psychologists and forensic experts are part of the investigation process. These individuals can judge and debate with the participants in order to solve the crime.

Along with Müge Anlı's investigation, other guests have their turn for commenting on the case related to their professions as well. For instance, Prof. Dr. Arif Verimli as in the psychiatrist role in this program explained the situation as a collective delirium. He speculated that what Palu family experiencing is a serious case of irregularity in their brain. That is why the members who lived with Tuncer Ustael are under the influence of him and they do not believe any factual events. The reason is that Tuncer Ustael declared himself as hodja and took control of this family. Thus, the guests who are part of Müge Anlı's team in this program claim to approach to the case "scientifically".

Müge Anlı sends her team to investigate the area because many witnesses accused Tuncer Ustael of burying Meryem Tahnal in this area. Also, she sent out reporters the house they used to live in, because in MATS "The reporters go the scene of the incident to investigate the case or talk with other witnesses" (Erol Işsk and Yaman, 2017: 73). Later police officers and other local personalities got involved in this investigation. They continued their investigation in the area in Kocaeli with the help of police officers, local authorities and dug this area to be able to find Meryem Tahnal's dead body. This activity in the program resembles the format defined by Cavender and Fishman, actual footage of police in action. In this format, "the audience sees and hears what the police see and hear. While this approach is touted as "the real thing," the programs are edited to air the most action-packed sequences (Cavender and Fishman, 1998: 4). With the localization of this format in Turkish television caused collaboration of police force and MATS and resulted with the footages of police forces wandering in the fields to locate a body or evidence.

Many of their neighbors of the family called the program and reported that there are violence and abuse within the family. There are several eyewitnesses not only in Istanbul but also in other cities in Turkey. In MATS news coordinator Gökhan Bektaş presents himself as a reporter. He visits crime scenes, victim's family houses, and locations as reporter and interviews with relatives, police or local authorities to help Müge Anlı to solve crimes. This feature of the MATS is from global reality crime program format. The vignettes feature interviews with victims, their family and friends, the police, and film and photographs of suspects. Viewers are urged to telephone the police or the program with information about crimes or suspects (Cavender and Fishman, 1998: 4). These video footages are shown during the program by Müge Anlı to share shreds of evidence with the audience. 
The case of the Palu Family continued until 9 January 2019. Ranking and rating of MATS during the Palu Family case showed that this case made MATS one of the most watched programs in Turkish television within this period. With the participation of the main suspect, Tuncer Ustael in the program, the rating started to increase. As Table 1 shows that, 9 January 2019 which is the date Tuncer Ustael and other members of the family have been arrested in live broadcast, has the highest rating of this program. This case continued thirteen days with the live broadcast on private channel ATV. The first seven days of the case the ratings of the program were not different than usual. However, after the first week, Müge Anl 1 and her team found out that the case is not only about murder but also there is violence and abuse present in the family. These issues raised the audience's interest in the case and also in the program. From the eight days of the case in the program, the rating increased constantly. Even after the family has been arrested on day thirteen, 9 January 2019, the audience kept on watching the program on the fourteenth day, 10 January 2019, for further information.

Table 1. The Television Rankings and Ratings of the Palu Family Case during Two Weeks

\begin{tabular}{|l|c|c|c|c|c|}
\hline DAY & DATE & RANK & CHANNEL & RATING & SHARE \\
\hline 1. & 21.12 .18 & 6 & ATV & 4.79 & 28.26 \\
\hline 2. & 24.12 .18 & 9 & ATV & 4.27 & 26.45 \\
\hline 3. & 25.12 .18 & 6 & ATV & 4.97 & 27.13 \\
\hline 4. & 26.12 .18 & 6 & ATV & 4.69 & 26.03 \\
\hline 5. & 27.12 .18 & 6 & ATV & 4.94 & 26.25 \\
\hline 6. & 28.12 .18 & 8 & ATV & 4.17 & 23.63 \\
\hline 7. & 31.12 .18 & 8 & ATV & 4.28 & 22.7 \\
\hline 8. & 02.01 .19 & 6 & ATV & 4.73 & 25.38 \\
\hline 9. & 03.01 .19 & 5 & ATV & 4.86 & 27.36 \\
\hline 10. & 04.01 .19 & 5 & ATV & 5.19 & 28.19 \\
\hline 11. & 07.01 .19 & 3 & ATV & 5.92 & 31.58 \\
\hline 12. & 08.01 .19 & 3 & ATV & 6.53 & 31.99 \\
\hline 13. & 09.01 .19 & 2 & ATV & 7.09 & 34.94 \\
\hline 14. & 10.01 .19 & 2 & ATV & 5.45 & 28.48 \\
\hline $\begin{array}{l}\text { The New } \\
\text { Case }\end{array}$ & 11.01 .19 & 8 & \multirow{2}{*}{ ATV } & 4.78 & 25.95 \\
\hline
\end{tabular}

Source: https://www.medyaradar.com/reyting-sonuclari/21-aralik-2018.

According to the Turkish BBC website, the discussed topics in the program were accepted as a warning by Kocaeli Chief Public Prosecutors Office. Afterward, the Office has compiled a file of accusations and opened an investigation towards the family. Family's five members in their house in Kocaeli, Tuncer Ustael and his wife Emine Ustael in Istanbul was taken under police supervision during the live broadcast of the program on 9 January 2019. Later the members of the Palu family, which are the mother Havva Palu, her sons Fatih and İsa and her daughter Ayşe, were arrested after the trial they were condemned with. However, the father Harun Palu was released. Alongside these names, Tuncer Ustael and his wife Emine Ustael were also arrested. A written statement by Kocaeli Chief Public 
Prosecutors Office states that the arrested six names are arrested under the accusation of murder in the first degree. These members are; Havva Palu, İsa Palu, Fatih Palu, Ayşe Melek Palu, Tuncer Ustael and Emine Ustael. The statement of the Chief Prosecutor Office mentioned that the research for the bodies of mother Meryem Tahnal and her daughter Melike Tahnal failed. The evidence of the murder of mother Meryem Tahnal and her daughter Melike Tahnal were sent to Sakarya Ferizli Chief Public Prosecutor's office for further investigation. There are several accusations toward Tuncer Ustael for sexual abuse for his own two children Samet Ustael and Zeynep Ustael also two children of Meryem Tahnal; Recep Tayyip Tahnal and Melike Tahnal. A local newspaper website Haberturk.com stated that the story of the Palu family caused awareness throughout the country. Many citizens called out to authorities through social media such as twitter and facebook that they should arrest family members.

\section{Conclusion}

This article revealed and argued the roots and several features of the crimebased reality programs in global television. Then, the localization ways and the process of these types of programs in Turkish television history were researched. Theoretical framework and literature review directed us to approach the article's hypothesis. Thus, many arguments on global and Turkish television history were stated. Then, MATS' uniqueness as a hybrid crime-based program and the role of the Palu Family case were examined. For that purpose, the content analysis method was used to define and describe MATS through fifteen episodes of the program during the Palu Family case.

The role of the media in the Palu Family case might also suggest that the boundaries between fiction and factual representation of crime are blurred. The case got the attention of Turkish citizens in a way that such a story of crime could be categorized in both reality television and news. The reason is that the case was solved in a television program. This program is in the format of entertainment programming, both serve information and entertainment. By the analysis of the Palu Family case, the specificity of MATS is explained with the hybridity comes from mixture of the information and entertainment. Thus, it could be claimed that MATS is infotainment. The hybridity of this program derives from the mixture of global reality programming. However, this program found its format on Turkish television. Therefore, the analysis of the MATS' unique format within the reality television programs -both local and international ones- could contribute to the television studies due to this divergent and unique format's way of investigating and the broadcasting the criminal cases in a different way from its ancestors. In other words, this program's uniqueness is based on the combination of crime program elements with court shows, talk shows features. As a result, MATS has dramatic narratives alongside the content which loops back into news reporting. Therefore, we reached a proper answer to the study's main research question that Müge Anlt ile Tatl Sert could be defined as a contemporary and hybrid Turkish 
crime-based reality program that makes MATS a unique format in Turkish television.

Moreover, this article revealed how MATS hybridizes different types of the crime-based programs and the ways of $M A T S^{\prime}$ in the creation of the unique and local format in Turkish television. Besides, the analysis of the Palu Family case proves the success of Müge Anl as the longest standing host of a crime-based reality program in Turkish television. Despite essential works of Kesirli (2017), Erol Işık and Yaman $(2017)$ and Çelenk $(2015 ; 2011)$ on Turkish reality television related to the crime content, the numbers of studies on the contemporary reality television formats in Turkish television do not reach considerable amounts. Therefore, the article's contribution to the field becomes essential to open new perspectives for forthcoming researches. By the content analysis on the Palu Family case, MATS is defined with its hybrid qualities. This result could broaden an understanding and provide a different perspective on the localization of the global and well-known formats in television studies.

\section{References}

Aksop, G. (1998). Türkiye'de Reality Show'lar. (Reality shows in Turkey). Master Thesis. Turkey: Ankara University.

Berger, A. A. (1975). The TV-guided American. New York: Walker \& Co.

Binark, M., Kılıçbay, B. (2004). Türkiye'de Gerçek Televizyonu ve Telegörsel Kimlikler: Biri Bizi Gözetliyor Örneği. (Reality television and televisual identities in Turkey: someone is watching us). Iletisisim Araştırmalarl, 2(1), 71-90.

Breslin, J. (1990). America's most wanted: how television catches crooks. New York: HarperCollins.

Carmody, D. C. (1998). Mixed messages: images of domestic violence on "reality" television. In G. Cavender, M. Fishman, (eds.), Entertaining Crime: Television Reality Crime Programs. New York: Routledge.

Cavender, G., Fishman, M. (1998). Entertaining crime: television reality crime programs. New York: Routledge.

Çelenk, S. (2005). Televizyon, Temsil, Kültürr. (Television, representation, culture). İstanbul: Ütopya Yayınevi.

Çelenk, S. (2011). The seal of culture in format adaptations: singing for a dream on Turkish television. In A. Hestroni, (ed.), Reality Television-Merging the Global and the Local, 137-149. New York: Nova Science Publishers: Hauppauge.

Erol Işık, N., Yaman, B. (2017). Crime and media: the world of 'reality show' as a moral frame of reference. Milli Folklor, 29(113), 69-78.

Hill, A. (2005). Reality TV: audiences and popular factual television. New York: Routledge.

Kazaz, M., Bayar, S. (2019). Haber Tartışma Programlarının Bir Türü Olarak Haber Mahkemeleri Programlarının Analizi: ATV, TV8, STAR TV Örneği. (The analysis of the news-court programs as a type of the news-discussion program: the case study of ATV, TV8, STAR TV). Selçuk İletişim Dergisi, 12(1), 186-198.

Kesirli, A. (2017). Genre, Globalization and the nation: the case of Turkish police procedural TV series. Turkey: Bahçeşehir University.

Kohm, S. A. (2009). Naming, shaming and criminal justice: mass-mediated humiliation as entertainment and punishment. Crime, Media, Culture, 5(2), 188-205. 
Murray, S., Ouellette, L. (2004). Reality TV: Remaking Television Culture. New York: NYU Press.

Penzhorn, H., Pitout, M. (2008). A critical-historical genre analysis of reality television, communication. South African Journal for Communication Theory and Research, 33(1), 62-76.

Sholle, D. (1993). Buy our news. Journal of Communication Inquiry, 7(1), 56-72.

Stark, S. (1987). Perry Mason meets Sonny Crockett: the history of lawyers and the police as television heroes. University of Miami Law Review, 42(1), 229-283.

Surette, R. (1997). Media, crime, and criminal justice: images and realities. $2^{\text {nd }}$ Edition. Belmont, California: Wadsworth Publishing. 
